INTER NATIONAL MONETARY FUND
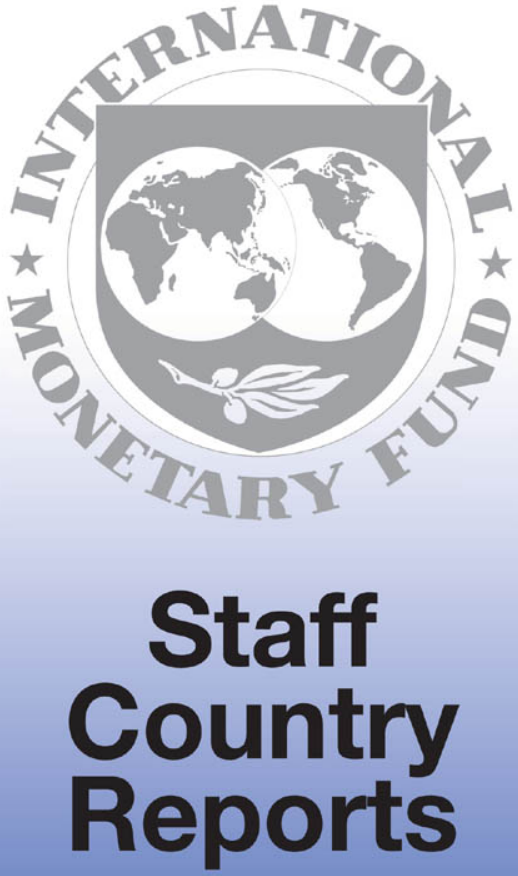
September 1998

IMF Staff Country Report No. 98/99

\section{Georgia: Recent Economic Developments and Selected Issues}

This Recent Economic Developments and Selected Issues report on Georgia was prepared by a staff team of the International Monetary Fund as background documentation for the periodic consultation with this member country. As such, the views expressed in this document are those of the staff team and do not necessarily reflect the views of the Government of Georgia or the Executive Board of the IMF.

Copies of this report are available to the public from International Monetary Fund - Publication Services 700 19th Street, N.W. - Washington, D.C. 20431

Telephone: (202) 623-7430 - Telefax: (202) 623-7201

Telex (RCA): 248331 IMF UR

Internet: publications@imf.org

Price: $\$ 15.00$ a copy

International Monetary Fund

Washington, D.C. 


\section{INTERNATIONAL MONETARY FUND}

\section{GEORGIA}

\section{Recent Economic Developments and Selected Issues \\ Prepared by a staff team consisting of Emmanuel van der Mensbrugghe, \\ Gonzalo Pastor, Niko Hobdari, Hunter Monroe (all EU2), \\ Kenneth Kang (PDR), and José Bailén (FAD) \\ Approved by the European II Department}

June 12, 1998

Contents

Page

Basic Data . . . . . . . . . . . . . . . . . . . . . . .

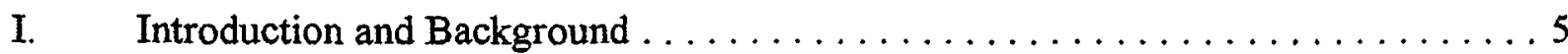

II. Recent Economic Developments $\ldots \ldots \ldots \ldots \ldots \ldots \ldots \ldots \ldots$.

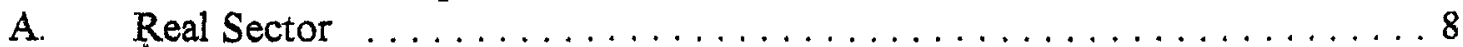

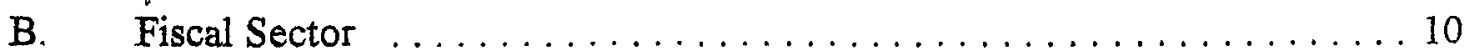

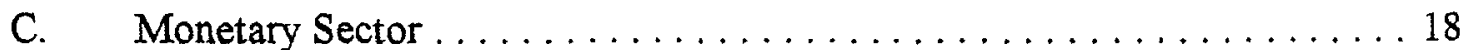

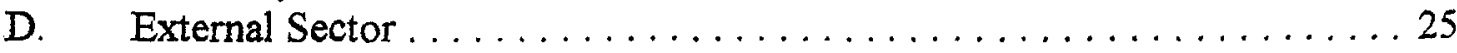

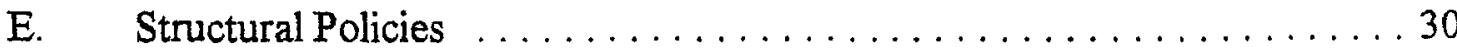

III. Business Environment and Foreign Direct Investment $\ldots \ldots \ldots \ldots \ldots \ldots 2$

IV. Revenue Mobilization: The Last Three Years $\ldots \ldots \ldots \ldots \ldots \ldots \ldots \ldots$

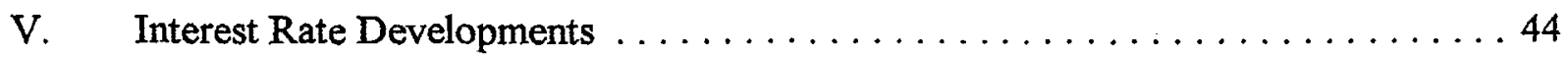

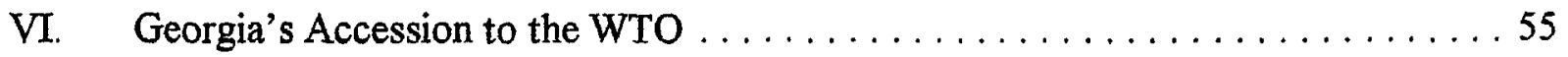

VII. Exchange, Trade and Payments Systems $\ldots \ldots \ldots \ldots \ldots \ldots \ldots 7$

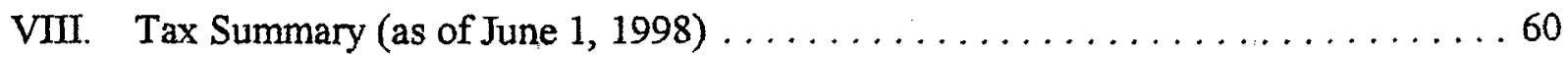

Text Boxes

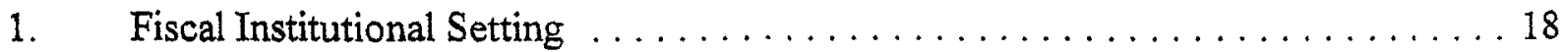

(CInternational Monetary Fund. Not for Redistribution 
2. A Chronology of Banking Sector Reform in Georgia . ............. 24

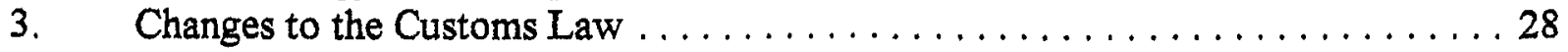

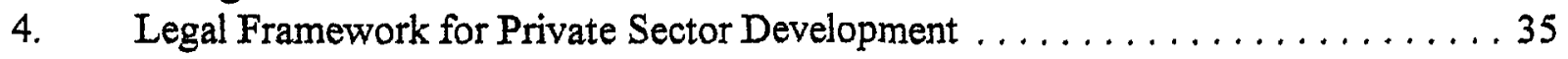

Text Tables

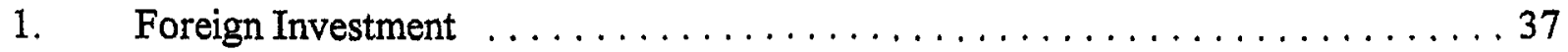

2. Tax Policy Measures and their Potential Revenue Impact . . . . . . . . . . . 39

3. Tax and Customs Administration Improvements . . . . . . . . . . . . 41

4. Fiscal Developments and Increases in the Tax Revenues/GDP Ratio . . . . . . . . 42

5. BRO Countries: General Government Revenue Developments, $1993-97$. . . . . . 43

6. BRO Countries: General Government Revenue Development, by Type of Tax, as of 1997 Q1-Q2 . . . . . . . . . . . . . . . . . . . . . . . . . . . 44

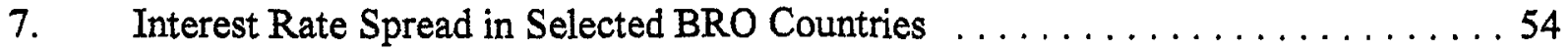

$8 . \quad$ Interest Rate Developments Surrounding the Banking Crises $\ldots \ldots \ldots \ldots \ldots 5$

$\underline{\text { Figures }}$

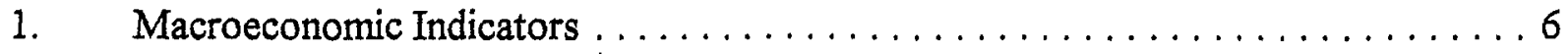

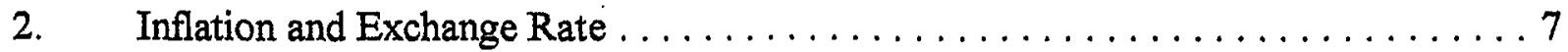

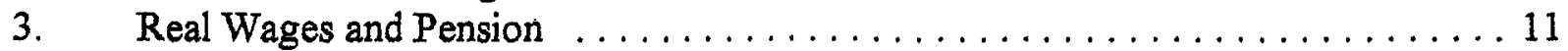

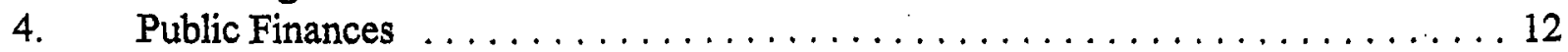

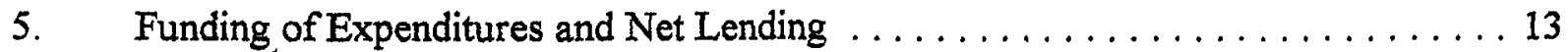

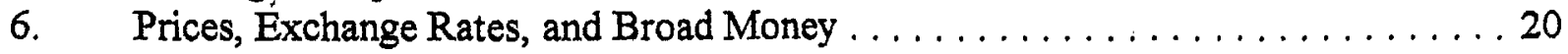

7. Currency in Circulation and the Money Multiplier $\ldots \ldots \ldots \ldots \ldots \ldots \ldots 21$

8. Bilateral Nominal and Real Effective Exchange Rate $\ldots \ldots \ldots \ldots \ldots \ldots 29$

9. Georgia and BRO: Composition of Total Revenue, 1997 Q1-Q2 ........ . 45

10. Outstanding Stock of Treasury Bill and Weighted Average Interest Rates . . . . . 47

11. Total Volume of Transactions, NBG Sales at the Interbank Credit Auctions and 7-day Maturity Interest Rate per Annum . . . . . . . . . . . . . . . 49

12. Total Volume of Transactions, NBG Sales at the Interbank Credit Auctions and 30-day Maturity Interest Rate per Annum . . . . . . . . . . . . . 50

13. Total Volume of Transactions, NBG Sales at the Interbank Credit Auctions and 90-day Maturity Interest Rate per Annum ............... 51

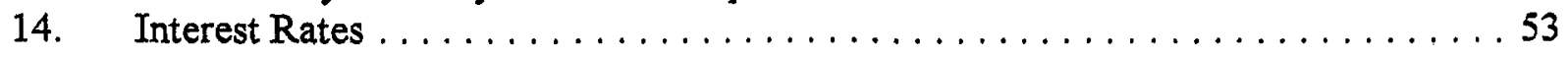

\section{$\underline{\text { Statistical Appendix Tables }}$}

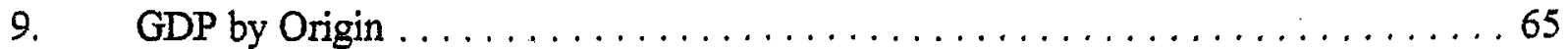

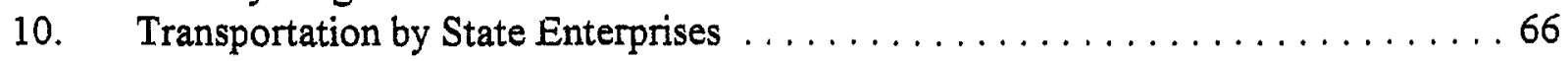

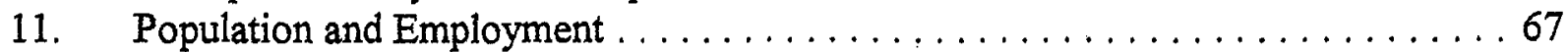

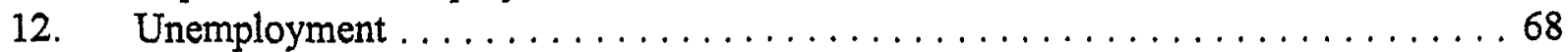

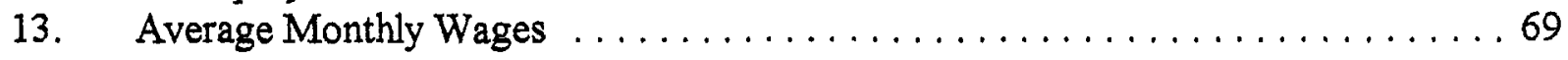




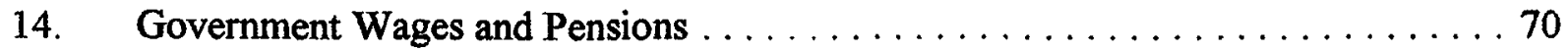

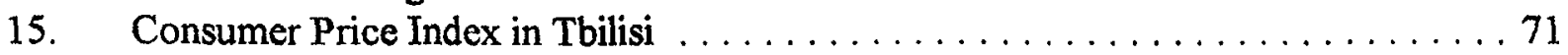

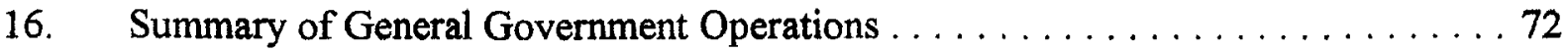

17. Summary of General Government Operations ...............73

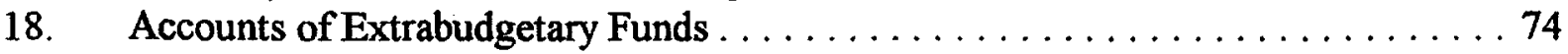

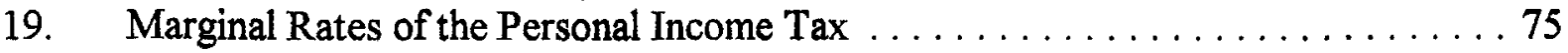

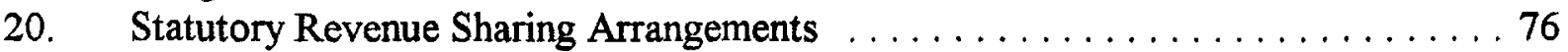

21. Number of Registered and Active Taxpayers $\ldots \ldots \ldots \ldots \ldots \ldots \ldots \ldots 77$

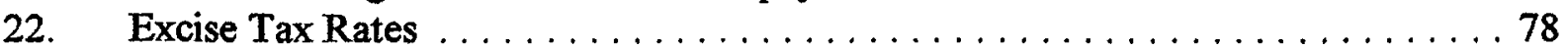

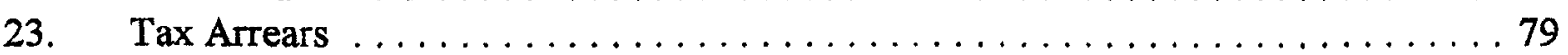

24. Public Expenditure in Education and Health $\ldots \ldots \ldots \ldots \ldots \ldots \ldots \ldots . \ldots .61$

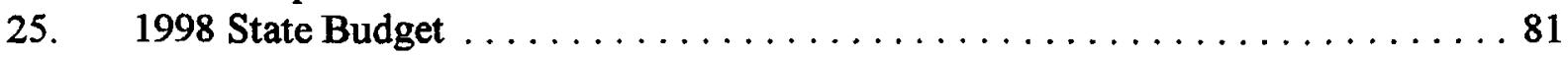

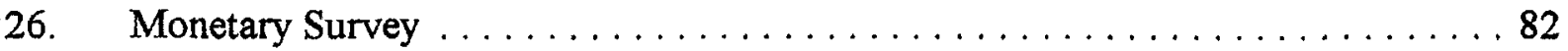

27. Accounts of the National Bank of Georgia $\ldots \ldots \ldots \ldots \ldots \ldots \ldots \ldots \ldots . \ldots \ldots 34$

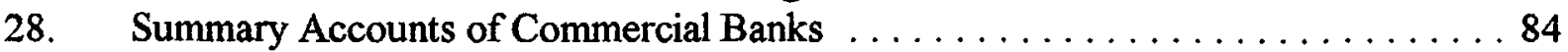

29. Structure of Commercial Bank Deposits . . . . . . . . . . . . . 85

30. Currency Composition of Commercial Bank Credit . . . . . . . . . . 86

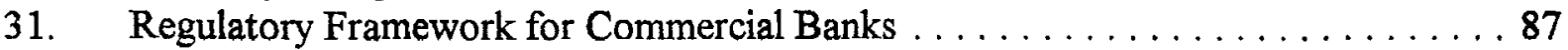

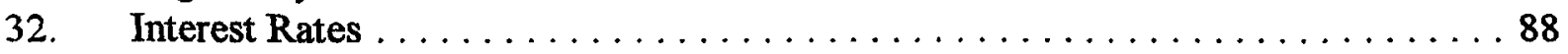

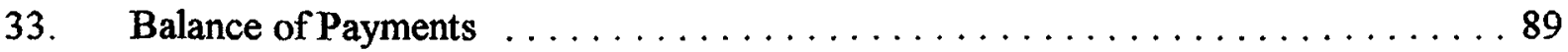

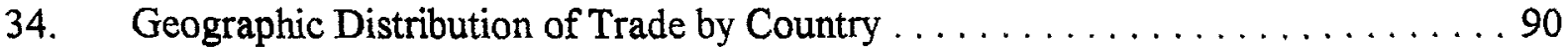

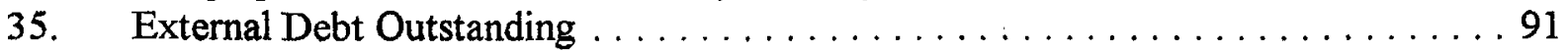

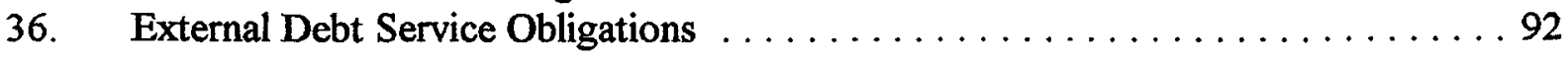

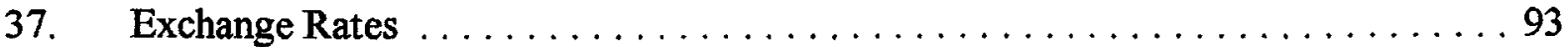


Georgia: Basic Data, 1993-1997

I. Social and Demographic Indicators

Area

Population density (1995)

Population (estimated 1995)

$69,700 \mathrm{sq} \cdot \mathrm{km}$

Population (estimated 1995)
percent urban

77.0 per sq. $\mathbf{k m}$

5.37 million

55.6 percent

Rate of population growth (1990)

0.1 percent

Life expectancy at birth (1990)

Infant mortality rate (per 10,000 people--1990)

72.6 years

Hospital beds (per 10,000 people-1990)

GDP per capita, $1997 \quad 1 /$

in lari

in U.S. dollars

II. Economic Indicators

\begin{tabular}{|c|c|c|c|c|c|}
\hline & $\begin{array}{l}1993 \\
\text { Act. }\end{array}$ & $\begin{array}{l}1994 \\
\text { Act. }\end{array}$ & $\begin{array}{l}1995 \\
\text { Act. }\end{array}$ & $\begin{array}{l}1996 \\
\text { Act. }\end{array}$ & $\begin{array}{r}1997 \\
\text { Prel } \\
\text { Est. }\end{array}$ \\
\hline & \multicolumn{5}{|c|}{ (Percent change) } \\
\hline \multicolumn{6}{|l|}{ Real sector } \\
\hline GDP volume & -25.4 & -11.4 & 2.4 & 10.5 & 11.0 \\
\hline \multicolumn{6}{|l|}{ Consumer prices } \\
\hline Period average & 3,125 & 15,607 & 163 & 39 & 7 \\
\hline \multirow[t]{2}{*}{12 months to end of period } & 7,488 & 6,474 & 57 & 14 & 7 \\
\hline & \multicolumn{5}{|c|}{ (Percent of GDP) } \\
\hline \multicolumn{6}{|l|}{ Government finances } \\
\hline Revenue and grants & 9.7 & 7.7 & 7.1 & 9.4 & 10.4 \\
\hline Ofwhich: Revenue & 2.3 & 4.2 & 5.1 & 8.1 & 10.0 \\
\hline Expenditure and net lending & 35.9 & 24.3 & 12.3 & 13.9 & 14.5 \\
\hline Balance (accrual) & -26.2 & -16.5 & -5.3 & -4.5 & -4.1 \\
\hline \multirow[t]{2}{*}{ Balance (cash) } & -26.2 & -7.4 & -4.5 & -4.4 & -3.8 \\
\hline & \multicolumn{5}{|c|}{ (Percent change, end-period) } \\
\hline \multicolumn{6}{|l|}{ Money and oredit } \\
\hline Net domestio assets of the NBG & 572.0 & $2,091.7$ & 156.5 & 158.5 & 53.2 \\
\hline Credit to enterprises and households $2 /$ & $2,048.0$ & $3,448.3$ & 39.9 & -14.0 & 34.9 \\
\hline \multicolumn{6}{|l|}{ Broad money } \\
\hline Including foreign currenoy deposits & $4,319.0$ & $2,229.5$ & 135.2 & 41.9 & 45.5 \\
\hline \multirow[t]{2}{*}{ Excluding foreign currency deposits } & $2,462.0$ & $1,796.7$ & 319.7 & 38.1 & 35.4 \\
\hline & \multicolumn{5}{|c|}{ (In millions of U.S. dollars) } \\
\hline \multicolumn{6}{|l|}{ Balance of payments } \\
\hline Merchandise exports & 457 & 381 & 363 & 417 & 463 \\
\hline Merohandise imports & -905 & -746 & -700 & -768 & .947 \\
\hline Trade balance & -448 & -365 & -337 & -351 & -484 \\
\hline Current account before transfers & -485 & .448 & -406 & -418 & -535 \\
\hline \multicolumn{6}{|l|}{ Official reserves, end-period, } \\
\hline (in millions of U.S. dollars) & 1 & 41 & 157 & 157 & 173 \\
\hline (in months of imports) & $\cdots$ & 0.7 & 2.7 & 2.5 & 2.2 \\
\hline \multicolumn{6}{|l|}{ Memorandum items: } \\
\hline $\begin{array}{l}\text { GDP, current prices (in millions of lari) } 1 / \\
\text { Exchange rate, lari per U.S. dollar }\end{array}$ & 16.4 & 1,373 & 3,694 & 5,724 & 6,798 \\
\hline Period average & $\therefore$ & 1.10 & 1.29 & 1.26 & 1.30 \\
\hline End period & 0.1 & 1.28 & 1.23 & 1.27 & 1.30 \\
\hline
\end{tabular}

Sources: Data provided by the national authorities; and staff estimates.

1/ The Georgian national accounts suffer from severe problems of coverage, measurement of deflators, and internal consistenoy.

2/ The sharp fall in 1996 reflects the carve out of a US\$41.6 million loan from the Turkish Eximbank to the Georgian former Eximbank.

Had this loan been included, oredit to enterprises and households would have grown by about 21 percent in nominal terms. 


\section{INTRODUCTION AND BACKGROUND}

1. During 1997 , the Georgian economy grew by 11 percent according to official estimates, while the average annual inflation rate continued its downwards path initiated in 1995 and reached single-digit levels of about 7 percent (Figures 1 and 2). The fiscal deficit (on a commitment basis) declined from 4.5 percent in 1996 to 4.1 percent in 1997, and the ratio of general government tax revenue to current expenditure (a proxy of public sector savings in the absence of adequate GFS classification of the fiscal accounts) increased significantly, as tax administration measures, together with the introduction of a new tax code, boosted tax revenue. Investment outlays of the general government, however, fell in real terms in 1997 as the government adjusted to a tighter budget constraint. The current account deficit widened from 9 percent of GDP in 1996 to 10 percent in 1997, mainly reflecting a rapid growth in imports associated with the construction and refurbishment of the "early oil" pipeline connecting Azerbaijan to the Black Sea. During 1997, significant gains were achieved in normalizing Georgia's relations with external creditors and making progress toward external viability.

\section{Monetary policy remained prudent in 1997, although the benefits of disinflation and} further bank restructuring did not translate into much lower interest rate levels than in 1996. Broad money grew rapidly during the year, albeit from very low levels by international standards. The expansion of central bank (net) credit to government was in line with the 1997 ESAF-supported economic program and the monetary authority managed to increase its gross reserve position to US\$173 million by end-1997 (equivalent to 2.2 months of imports of goods). The nominal lari exchange rate remained stable at an annual average rate of lari 1.3 per U.S. dollar.

3. The implementation of the government's structural reform program moved forward in 1997. Privatization of medium- and large-scale enterprises accelerated in the second half of the year in the context of the World Bank's second Structural Adjustment Credit (SAC II). Energy sector reform also advanced as the authorities enacted the Electricity Law, which set new parameters for government's involvement in the sector and the establishment of a competitive market for electricity distribution and generation over the coming years. Payments collection of electricity bills and electricity tariffs increased in line with the authorities' efforts to improve the financial position of the main electricity companies. Agricultural land privatization made further progress with the distribution of about 60 percent of cultivated land to private farmers by end-1997. Public expenditure control improved with the treasury system expanding to cover almost all central government spending units and the Pension Fund. Progress with banking sector reform included, inter alia, the announcement of a scheduled increase in minimum capital requirements through 2000; the development of timely indicators to monitor banks' compliance with prudential regulations; and further on-site examinations of commercial banks. A main task ahead for establishing a more attractive business environment in Georgia embodies a better (i.e., less $a d$ hoc) and more transparent implementation of the many laws enacted by parliament over the last three years. 
Figure 1. Georgia: Macroeconomic Indicators
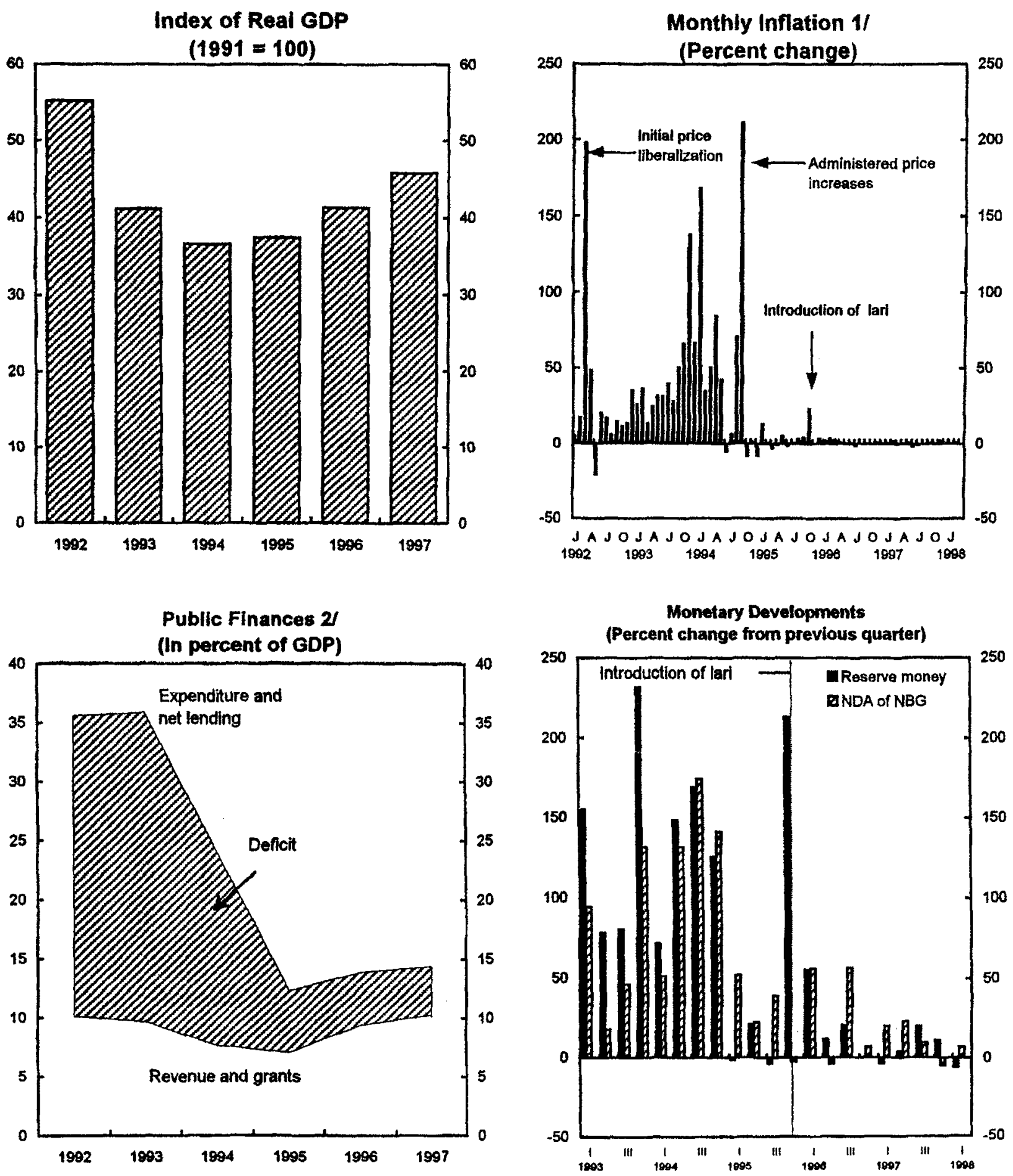

Sources: Georgian authorities; and Fund staff estimates.

1/ Before December 1993, based on the Retail Price Index; after December 1993, based on a 295good Laspeyres index.

2/ Commitment basis. 
Figure 2. Georgia: Inflation and Exchange Rate, 1994-98

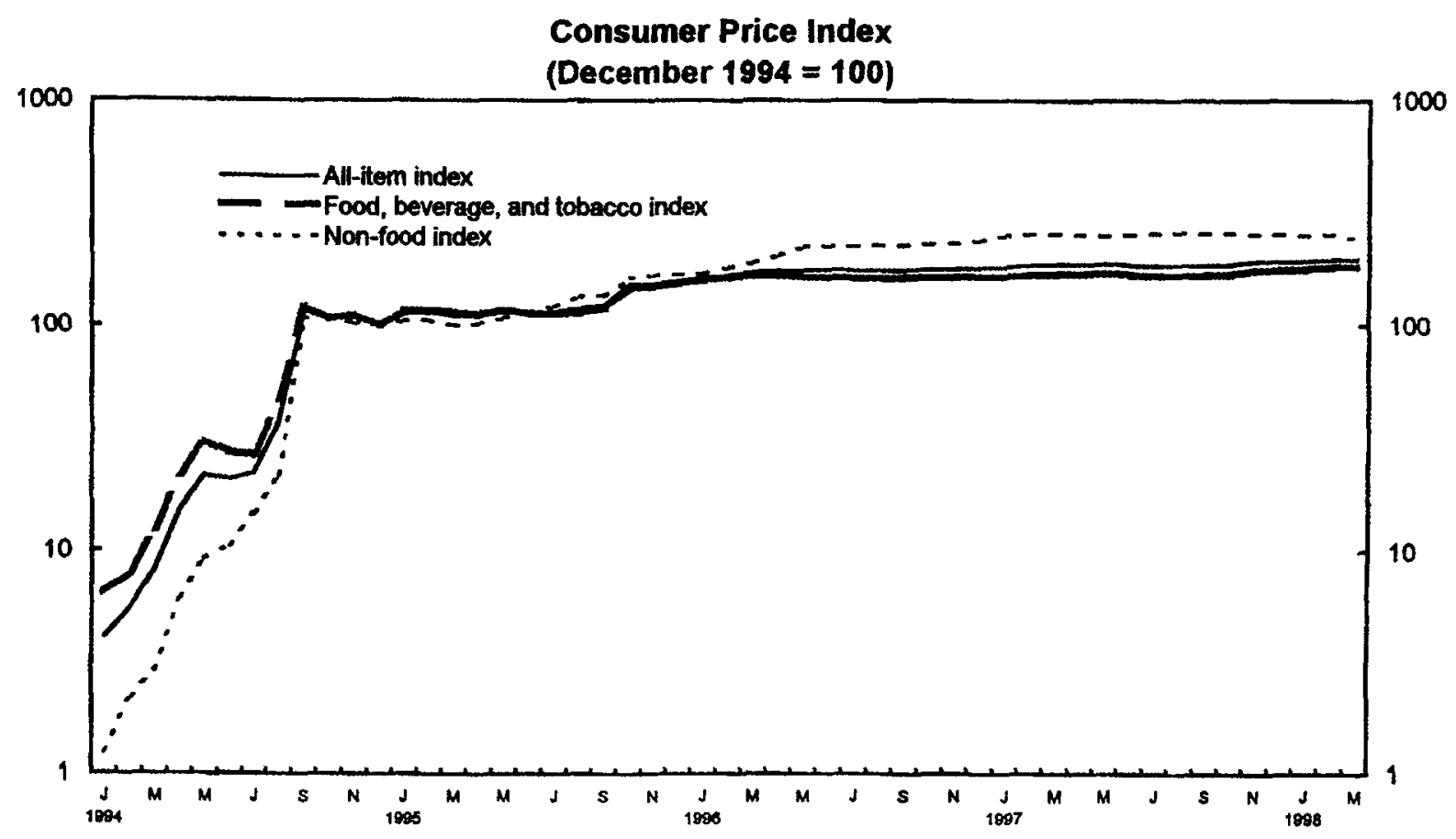

Exchange Rate Developments 1/

(Lari/U.S. dollar, end of period)

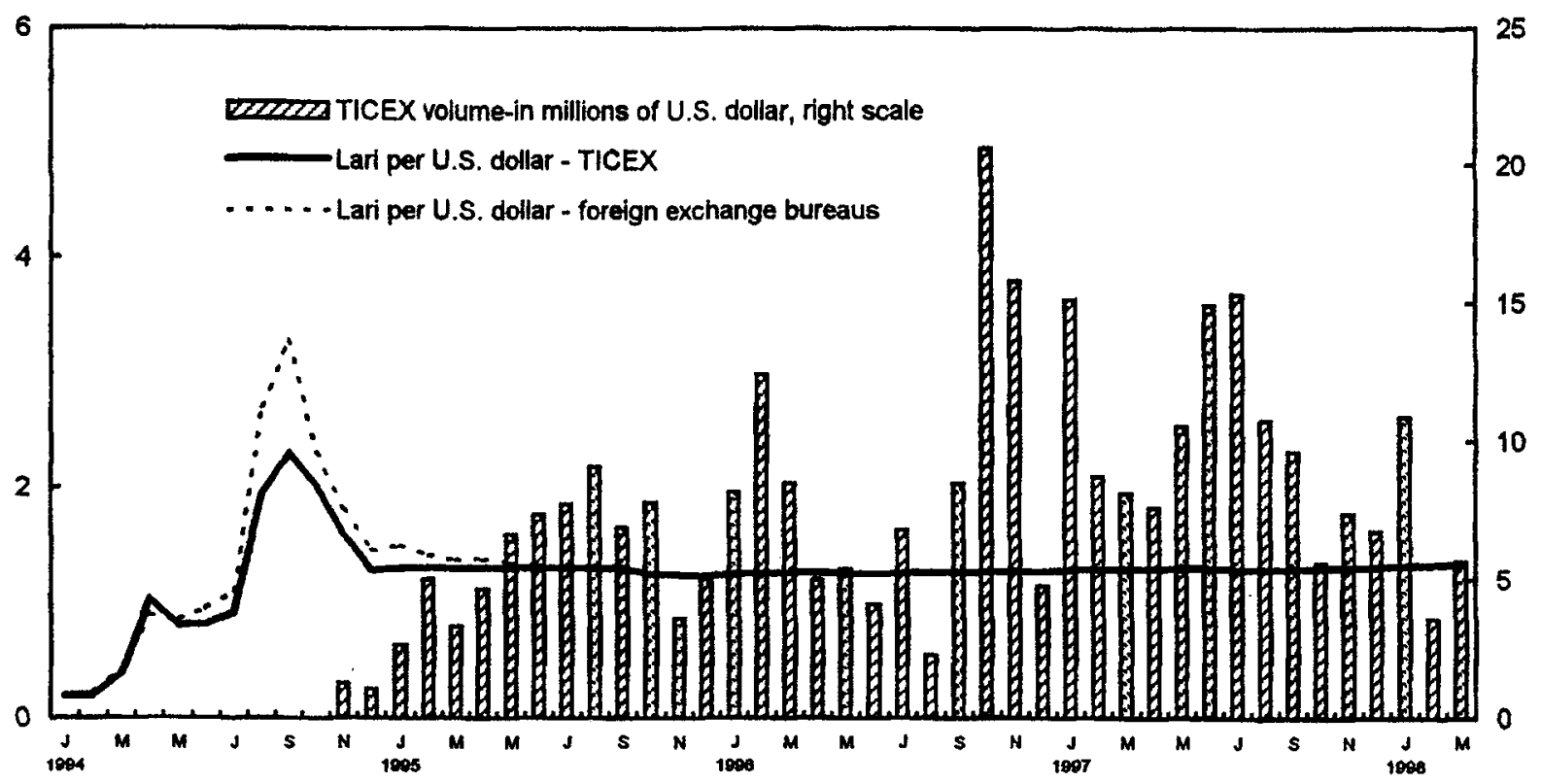

Sources: Georgian authorities; and Fund staff estimates.

1/ Increase means depreciation. 


\section{RECENT ECONOMIC DEVELOPMENTS}

\section{A. Real Sector}

\section{Output and demand}

4. Real GDP ${ }^{1}$ continued to increase at a fast pace during 1997, albeit from a very low base. For a second year in a row, output growth-officially estimated-exceeded 10 percent (Appendix I, Table 9). A sustained increase in the services sector, together with a booming agricultural sector explained these developments. By contrast, industrial output remained depressed, as many large-scale enterprises have not yet been either privatized or restructured, and the rest of enterprises are either operating in the informal sector (whose coverage in the national accounts statistics remains incomplete) or are growing less rapidly than other sectors in the economy due in part to working capital constraints.

5. The services sector has increased very rapidly since independence and is now a leading sector in Georgia's economic recovery. During 1997, trade and construction activities appeared to have continued to grow at double digit rates, although precise official estimates still need to overcome measurement problems in assessing the volume of activity in these two sectors. The recovery of the transport sector has been modest, reflecting in part the impact of the poor conditions of the domestic transport infrastructure (Appendix I, Table 10). Also, the rail link to Russia remains closed as it is situated in Abkhazia. As the pipeline for the "early" oil from the Caspian Sea is being laid in Georgia, some oil is already being transported by train across Georgia to the Black Sea port of Poti. International investors have expressed interest in investing in the Poti port and Turkey is funding much of the work of a rail link between Georgia and Turkey. The EU has funded the rehabilitation of an important road bridge on the Azerbaijan border and it is also promoting the development of transport routes across the whole region.

6. During 1997, Georgia registered a record grain harvest. Despite earlier worries about excessive rainfall, this phenomenon appeared to have been confined to only a few localities. Much of the success with grain production can be attributed to a recovery in output yields (for wheat, sunflower, and maize), the growing entrepreneurship of the private farmers, and the availability of financial resources provided under the EU TACIS regional agricultural reform project. Despite the success of the 1997 harvest, efforts still need to be made in diversifying and increasing the production of crops other than grains and agroprocessing activities. In addition, the provision of seeds for winter planting still remains problematic with many farmers having to access supplies directly from Russia, and the provision of financial resources to the agricultural sector remains very limited.

${ }^{1}$ Official GDP estimates suffer from serious methodological problems. In cooperation with the IMF, the authorities are close to starting a major overhaul regarding the compilation of national accounts statistics. 
7. The volume of industrial production remains stagnant. Many of the larger industrial enterprises have not yet been restructured and/or have been operating below capacity. The dynamism of the small-scale enterprises is not necessarily captured by the official statistics as many of these firms still operate in the informal economy. Moreover, while a number of laws and regulations have been enacted in recent years to enhance the business climate in Georgia much remains to be done to forcefully establish the rule of law in the country (Section III).

8. A major obstacle to private business development in Georgia has been the poor state of the energy sector. Power cuts are common and the added cost of generating one's own electricity supply (through the use of power generators) remains a major cost burden to many enterprises. Although the Enguri hydroelectric power plant was partly rehabilitated by mid1997, power supply did not improve much thereafter because of problems with the financial position of the electricity distribution companies, as well as water supply and the poor technical condition of most electric transmission plants. On the other hand, payments collection in the electricity sector remains very low for both households and industry. While households and industrial electricity tariffs were unified at tetri $4.5 \mathrm{per} \mathrm{Kw} / \mathrm{hour}$ in August 1997, this increase still did not provide for an investment and a maintenance program for the sector, and the tariffs remained below cost recovery levels. With the help of the World Bank and others, the authorities are currently preparing the privatization of the energy sector, starting with Telasi, one of the main electricity distribution companies in Georgia.

\section{Labor market developments}

9. According to official estimates, total employment in Georgia increased slightly between end-1996 and end-1997 (Appendix I, Tables 11 and 12). These figures, however, need to be treated with caution because of the poor coverage of informal activities, the risk of double counting as a consequence of the frequency of multiple employment, and various methodological problems with the official data. The share of self-employment in total employment reached 68 percent at end-1997. In agriculture, commerce, and construction, self-employment reportedly accounts to over 85 percent, 70 percent, and 40 percent of total employment, respectively. The economy's unemployment rate, as reported in the national households survey, declined from about 11 percent in the last quarter of 1996 to about 6.5 percent in the second quarter of 1997 . The unemployment rate was about 4 percent in rural areas and 18 percent in urban centers by end-June 1997 (Tbilisi's unemployment rate was about 23 percent).

10. Real wages in the formal economy continued to increase during 1997, with the largest gains recorded in trade and distribution, state administration and management, and credit and insurance (Appendix I, Tables 13 and 14). Official data indicate that the economy's average monthly nominal wage rose by 89 percent to lari 55 , corresponding to a real wage increase of 
over 75 percent. ${ }^{2}$ However, at this level, average wages in U.S. dollars remained very low (US\$40). The monthly minimum wage and pension have been lari 15 and lari 12 , respectively, since August 1997 (Figure 3). No reliable information is available about wages in the informal economy.

\section{Prices}

11. Annual consumer price inflation continued to decline in the context of tight financial policies from 57 percent in 1995 (end-period basis) to 14 percent in 1996 and 7 percent in 1997 (Appendix I, Table 15). Relative price developments showed a continuation of the trend for services prices to rise faster than goods prices, in large part owing to sharp increases in utility tariffs (i.e., electricity, metro and train fares). The opening of the economy to international competition together with a tight monetary policy (Section II C) contributed significantly to the low inflation of traded goods.

\section{Background}

\section{B. Fiscal Sector}

12. Since 1994, the financial position of the general government has improved significantly as total revenue increased at an average real rate of nearly 40 percent per year and total expenditure was significantly trimmed (Figure 4 and Appendix I, Tables 16-18). The revenue/GDP ratio is now 10 percent, compared to 4 percent in 1994. Most of the revenue increase has been due to improvements in tax administration and the elimination of many broad tax exemptions. However, the marginal increase in tax revenue has been declining in the last two years, reflecting mainly diminishing gains from tax administration improvements and the lack of far-reaching revenue raising measures (Section IV). On the other hand, total government expenditure was reduced from 23.5 percent of GDP in 1994 to 11.6 percent in 1995, before rising again and reaching 14.4 percent of GDP in 1997. Most of the expenditure cuts were achieved through an elimination of bread and gas subsidies, and a reduction in the number of budgetary positions from 625,000 in 1994 to about 340,000 by end-1997. As a result of the revenue increase and the expenditure cuts, the budget deficit (on a commitment basis and including grants) fell from 16.5 percent in 1994 to 4.1 percent of GDP in 1997. Due to the deceleration of the revenue increase and lower external grants, the budget deficit reduction between 1996 and 1997 (from 4.5 percent of GDP to 4.1 percent of GDP) was relatively modest.

13. The composition of the budget deficit financing changed during the last four years. Foreign financing declined steadily from 6.0 percent of GDP in 1994 to 1.4 percent in 1997, while domestic financing (mostly; central bank lending) increased from 1.4 percent of GDP in 1994 to an average of 2.4 percent of GDP in 1996-1997 (Figure 5). Treasury bills were

${ }^{2}$ For budgetary organizations, average monthly wages rose from lari 23 in 1996 to lari 36 in 1997, an increase of about 55 percent. 
Figure 3. Georgia: Real Wages and Pension 1/
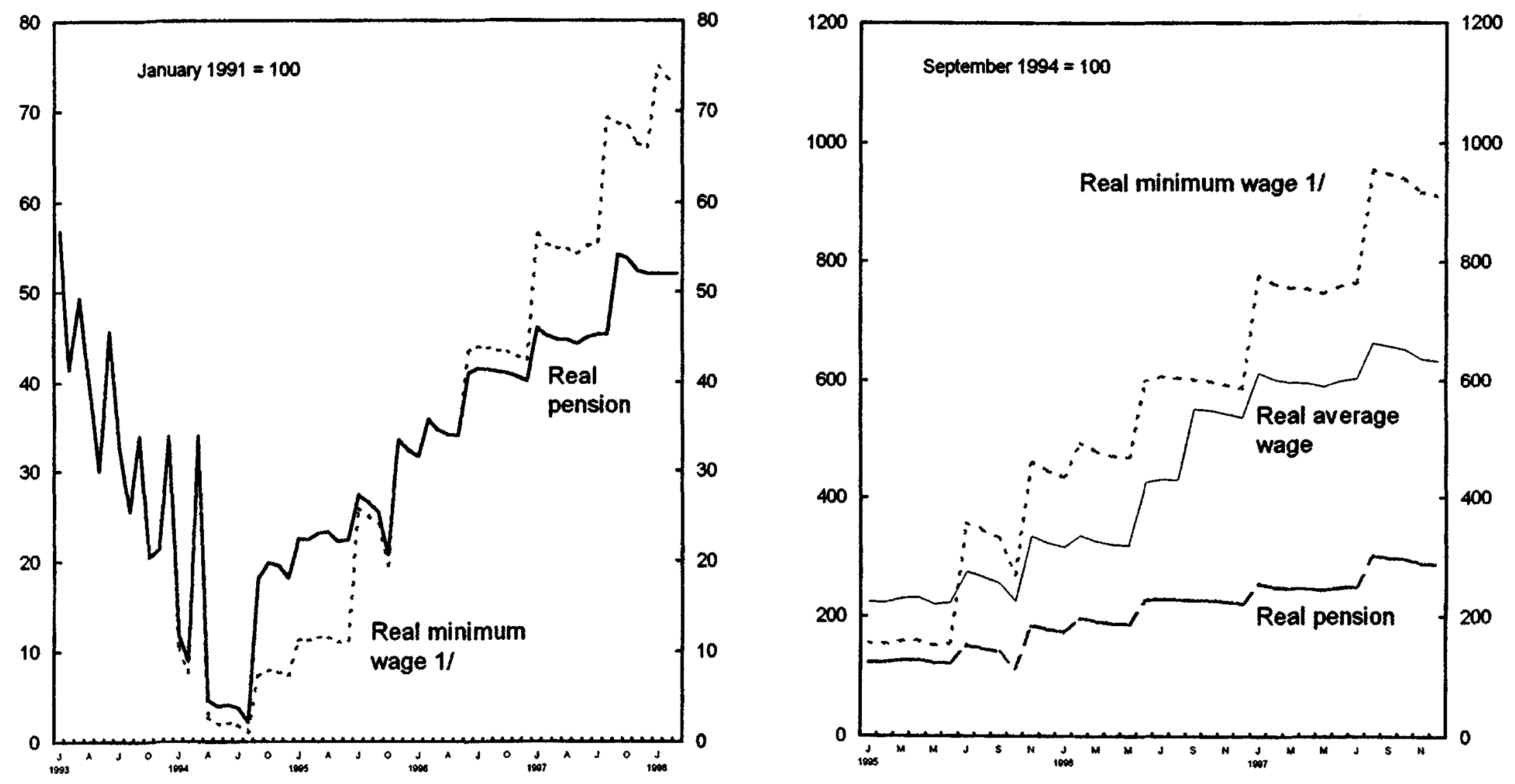

Sources: Georgian authorities; and Fund staff estimates.

1/ Wages in budgetary organizations. 
Figure 4. Georgia: Public Finances
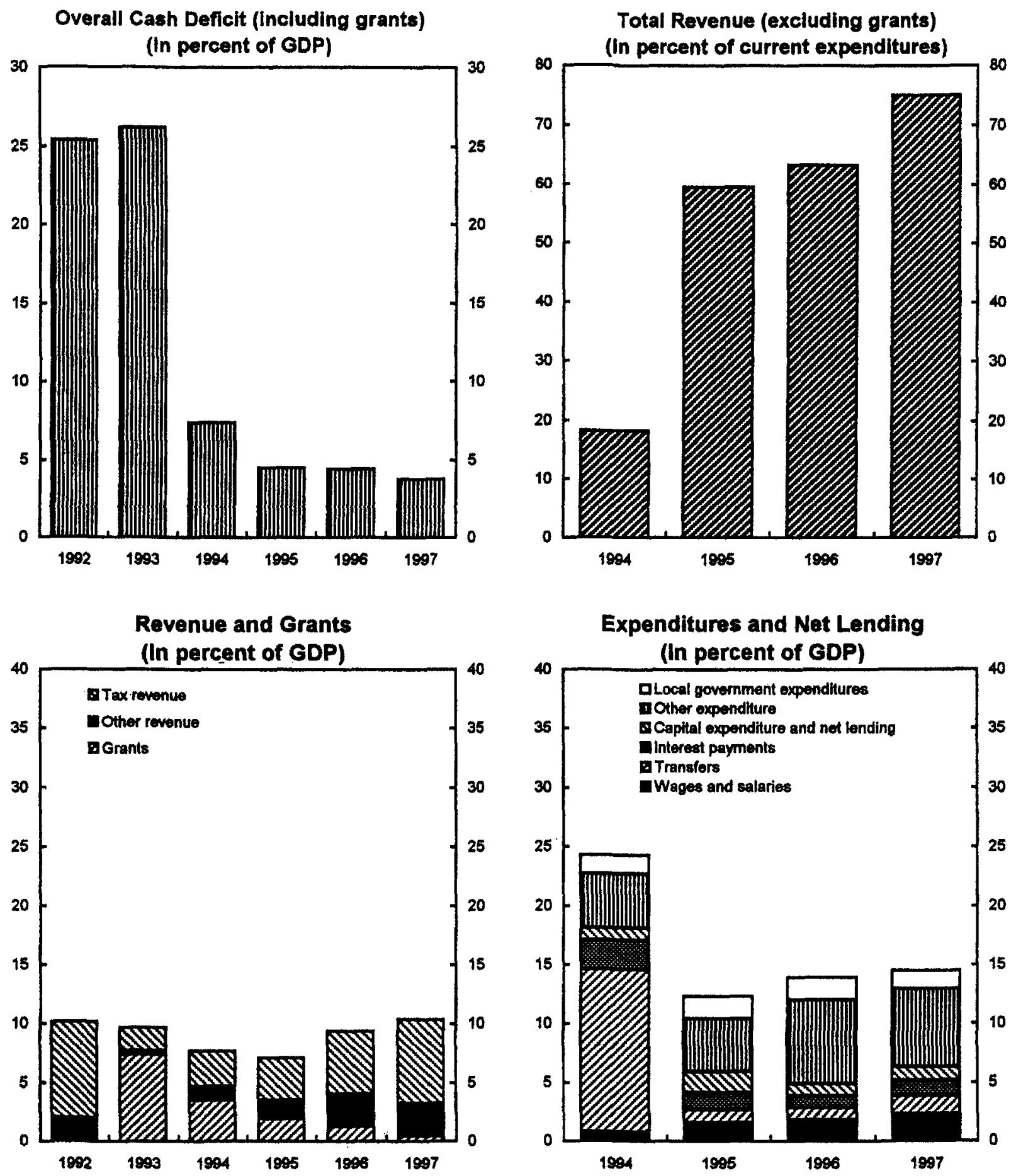

Sources: Georgian authorities; and Fund staff estimates. 
Figure 5. Georgia: Funding of Expenditures and Net Lending
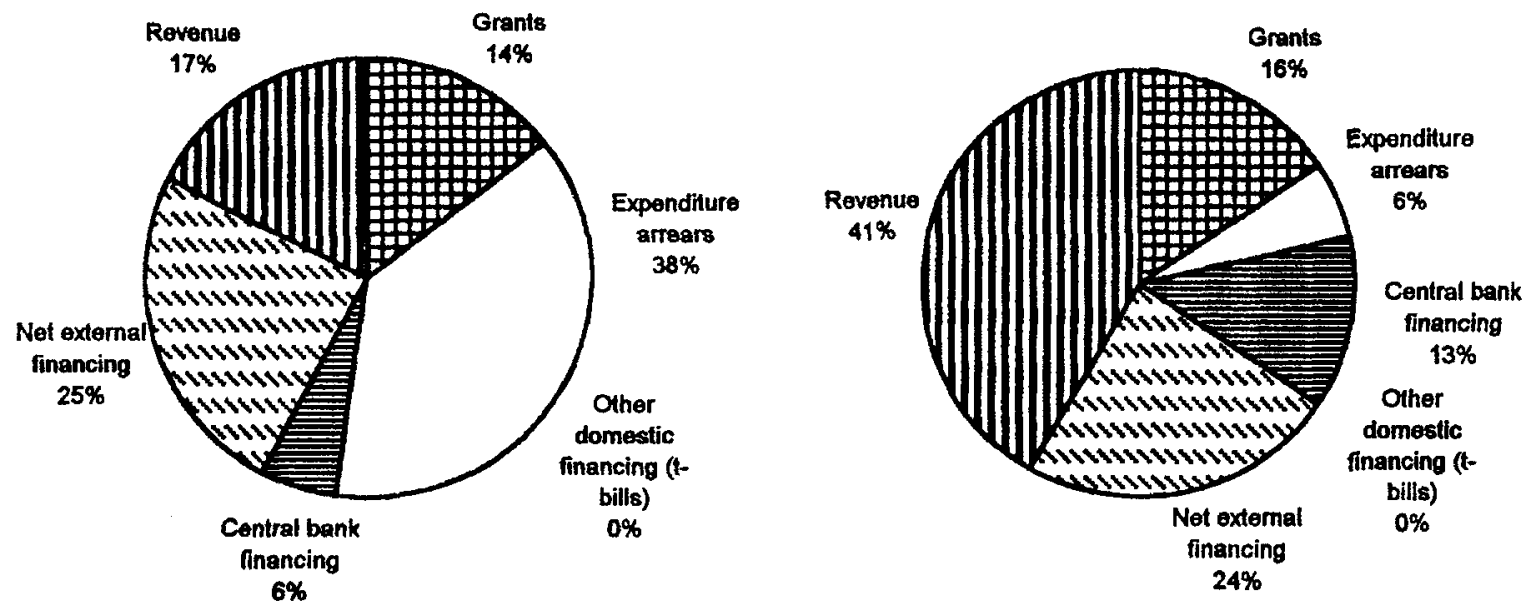

1996

1997
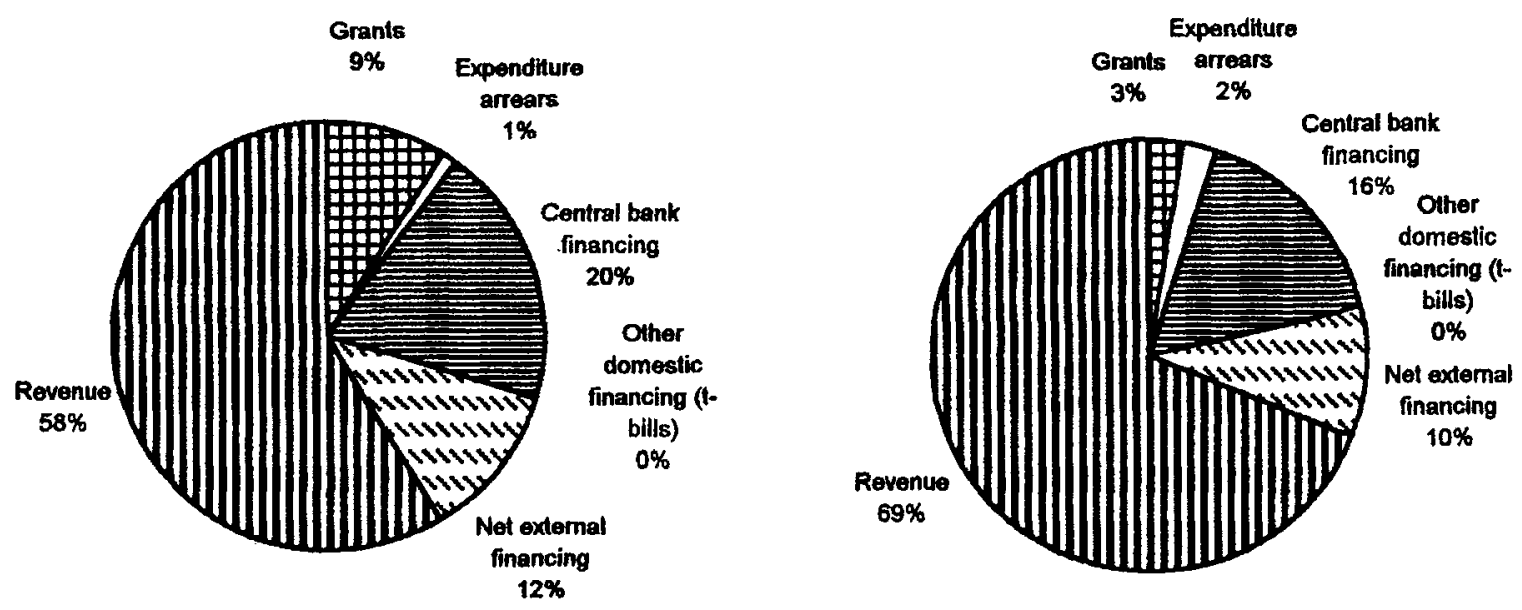

Sources: Georgian authorities; and Fund staff estimates. 
introduced in August 1997, but accounted only to some 4 percent of all domestic financing in 1997. High interest rates paid on these financial instruments (in the range of 30-40 percent) reduced the incentives for a more substantial issue of treasury bills (Section V).

\section{Fiscal performance in 1997}

14. The general government cash deficit totaled lari 256 million in 1997, or 3.8 percent of GDP in 1997. The cash deficit was slightly lower than the deficit on a commitment basis, due to an accumulation of expenditure arrears, which rose by 0.3 percentage points of GDP in 1997. Nearly two thirds of the cash deficit was financed with domestic sources. Disbursements from the World Bank under SAC II (US\$40 million) and various project support loans, (US\$12.8 million) were the main source of external financing of the general government deficit. ${ }^{3}$

\section{Revenues and grants}

15. Total revenue increased from 8.1 percent of GDP in 1996 to 10 percent of GDP in 1997. A main factor behind this improvement was a better tax and customs administration. The highest revenue increase was due to the collection of customs duties and was in part related to the removal of the customs duty exemption on imports of petroleum products and automobiles. Personal income tax and VAT revenue increased in line with the real increase of tax revenue (36.9 percent), ${ }^{4}$ whereas the performance of excise duties, profit taxes, and payroll taxes grew less than envisaged.

16. Excise duties and payroll taxes collections grew by less than the real increase in tax revenue, largely reflecting reductions in tax rates introduced in January $1997 .{ }^{5}$ For example, the excise duty on beer was reduced from 100 percent to 15 percent (Appendix I, Table 22); the duty on vodka and brandy was cut in half from 100 percent to 50 percent, whereas for passenger cars, the reduction was from 30 to 15 percent. The combined payroll tax rate was also reduced from 35 to 33 percent in January 1997.

${ }^{3}$ The EU continued to provide financial assistance in the form of grants (paragraph 21).

${ }^{4}$ The real increase in tax revenue is defined as the sum of tax revenue and extrabudgetary revenue, deflated by the average annual growth of the consumer price index. The marginal rates of the personal income tax are provided in Appendix I, Table 19, the statutory revenue sharing arrangements in Appendix I, Table 20, and the number of registered and active taxpayers in Appendix I, Table 21.

sAt the time of the 1997 program negotiations with the Fund, the authorities argued that a reduction in excise duties would be instrumental in increasing collections from these taxes. 
17. Another factor explaining the low collection of excise duties was the sharp decline in cigarette tax collections during the last three months of 1997. Between March and August 1997, the authorities applied a specific tax per pack of imported cigarettes (high and low quality cigarettes), which was substantially lower than the equivalent ad valorem rates approved by parliament. The specific tax was set at lari 0.06 through August and then increased to lari $0.08 / 0.09$ during that month, with cigarette tax collections increasing from an average of less than 1 million during the early months of the year to an average of lari 3 million during March/August 1997. In October, the specific tax on high and low quality cigarettes was increased to lari 0.25 per pack and lari 0.19 , respectively. However, cigarette tax collections dropped to less than lari 1 million per month in the last quarter of 1997 due to widespread smuggling and a lack of enforcement of the new tax rates.

18. Corporate profit taxes remained roughly unchanged in nominal terms between 1996 and 1997, notwithstanding the rapid growth of economic activity. The unification of multiple corporate profit tax rates at 20 percent-which replaced a system wherein banks' profits were taxed at 35 percent, industrial enterprises' profits at 10 percent, and the rest of the enterprises at 20 percent-had an overall negative effect on collections, although the policy was consistent with the government's efforts toward simplification of the tax system.

19. Nontax revenue increased slightly below the average real increase in tax revenue. This reflected the government's inability to collect loans granted to energy sector enterprises. Privatization revenues remained relatively low, at about lari 13 million, or 0.2 percent of GDP.

20. Tax arrears increased by nearly 50 percent in 1997, reaching about lari 170 million, or 28 percent of total tax collection by year-end (Appendix I, Table 23). Arrears to the Pension Fund increased from lari 40 million by end-1996 to lari 63 million by end-1997. Arrears to the Tax Inspectorate of Georgia (TIG) also increased from about lari 79 million by end-1996 to more than lari 100 million by end-1997. Overdue late penalties amounted to about the same fraction of total tax arrears in 1996 and 1997 (40 percent).

21. External grants fell to lari 26 million in 1997, or 0.4 percent of GDP, compared with lari 71 million in 1996, or 1.2 percent of GDP. About half of these grants were provided by the EU (under the Food Security Program), whereas the rest was provided by the Dutch government and by the revenue from the sale of U.S. wheat.

\section{Expenditure}

22. On a commitment basis, government expenditure increased from 14.1 percent of GDP in 1996 to 14.4 percent in 1997 reflecting the sharp increases in pensions, social transfers, wages, and domestic interest payments, which grew by more than the increase in nominal GDP. Expenditure in goods and services grew by less than nominal GDP, while capital expenditure remained virtually constant as a share of GDP. Overall, the pace of 
expenditure growth slowed down significantly with respect to 1996, a year in which government expenditure increased by 33.7 percent in real terms.

23. Wages and salaries increased by 15 percent in January and 10 percent in August. The average monthly wage in budgetary organizations rose from nearly lari 30 at end-1996 to lari 37.5 at end-1997. Minimum wages in the budgetary sector increased by more than the average (from lari 9 at end-December 1996 to lari 15 at end-December 1997), and currently represent 40 percent of the average wage, compared to 30 percent at the end of 1996 . The number of budgetary positions decreased from about 360,000 at the end of 1996 to about 340,000 at the end of 1997. Most of the employment reductions were in the education sector. In particular, effective November 1, 1997, about 10,000 budgetary positions were eliminated in the pre-schooling education sector, which was privatized and is now mainly financed through parents' fees. Despite the reductions in the last three years, the level of government employment is still high, representing nearly 20 percent of total employment in the economy. This is more than twice the level of employment in other economies with similar levels of development. The overstaffing of the public sector becomes evident in areas like primary education, in which the student/teacher ratio, at about ten, is even lower than in the most advanced industrial countries.

24. Social spending (pensions, unemployment allowances, refugee benefits, family and student allowances, and basic health care) increased substantially in 1997, and now represents about 5 percent of GDP. Pensions and other social benefits increased by 15 percent in January and 20 percent in August, outpacing the growth of wages. Also, health expenditures grew by about 65 percent in real terms, and now represent 1 percent of GDP (versus 0.7 percent of GDP in 1996) (Appendix I, Table 24).

25. Expenditure in goods and services (excluding health expenditures) grew moderately in 1997, although by more than the average annual inflation. Defense expenditures increased by less than the growth of nominal GDP, while other expenditures (e.g., office supplies, business trips) also grew moderately during 1997.

26. Accrued interest payments on domestic debt more than tripled in nominal terms between 1996 and 1997. This reflected mainly the increase in government outstanding debt to the National Bank of Georgia (NBG). ${ }^{6}$ Interest payments on treasury bills were only about lari 0.4 million in 1997. Accrued interest payments on external debt increased slightly from lari 46 million in 1996 to lari 54 million in 1997 (equivalent to 5.5 percent of total general government expenditure on a commitment basis) mainly as a result of new external loans.

27. Capital expenditure remained at a very low level, representing just 1.1 percent of GDP in 1997.

${ }^{6}$ The stock of general government debt to the NBG through end-1997 bears an interest rate of 15 percent (except for a small fraction that bears an interest of 1 percent). 
28. Local government expenditures (other than wages and salaries) decreased from 1.9 percent of GDP in 1996 to 1.5 percent in 1997. The privatization of pre-schooling education reduced local government expenditures in these expenditure categories.

\section{Expenditure management and control}

29. The stock of domestic expenditure arrears increased substantially in 1997, from lari 32 million at the beginning of the year to lari 70 million (or 1 percent of GDP) at the end of 1997. Of this total, about lari 20 million were interest payment arrears to the NBG, which were settled in March 1998 through an NBG net profit transfer to the government. Wage and pension arrears remained at about lari 12 million by end-1997. Pension arrears amounted to about one month of average pension outlays.

30. The development of a treasury system at the Ministry of Finance continued in 1997. An important step in this direction was the closure of all special accounts of central government spending units, except some accounts of the Pension Fund and the accounts of higher education institutions.

\section{The 1998 budget}

31. The 1998 state budget was approved by parliament in December 1997 (Box 1 and Appendix I, Table 25). The budget assumed an annual growth rate of real GDP of 10 percent and an annual average consumer price inflation of 8 percent. Key features of the budget included:

An increase in the revenue/GDP ratio of general government in 1998 from 10 percent of GDP in 1997 to 11.5 percent in 1998 resulting from the adoption of a number of tax policy and tax administration measures on January 1, 1998. These measures included: (i) the introduction of a surcharge on the land tax and the introduction of a presumptive income tax on small businesses in urban areas; ${ }^{7}$ (ii) increased collections of excise duties on cigarettes; and (iii) a number of tax administration measures covering, inter alia: further efforts to collect tax arrears, an expansion in the number of registered taxpayers, a broadening of the coverage of the Large Taxpayer Unit, progress with the computerization of tax offices, and the functional reorganization of the Tbilisi tax office.

- An average across-the-board increase in civil servants' wages and pensions of 15.5 percent in 1998 (10 percent increase in January 1, 1998 and an additional 10 percent increase in July) and a reduction in the number of budgetary positions. The

${ }^{7}$ In the event, the introduction of the surcharge on the land tax was postponed until January 1 , 1999. 
capital expenditure/GDP ratio was projected to remain unchanged with respect to 1997, at about 1.1 percent of GDP.

A further reduction in the general government budget deficit. On a commitment basis, and excluding net lending, ${ }^{8}$ the budget deficit was targeted at lari 153.8 million, or 1.9 percent of GDP in 1998 (compared to 4 percent of GDP in 1997). On a cash basis, the budget deficit was targeted at lari 177 million, or 2.2 percent of GDP. Of this amount, lari 23.2 million was earmarked toward the reduction of expenditure arrears.

\section{Box 1. Fiscal Institutional Setting}

The state budget of Georgia includes the budget of the central government and the budgets of extrabudgetary funds: the Social Security Fund (SSF), the Employment Fund (EF), the Road Fund, and the Privatization Fund. The Health Fund, was transformed into the State Health Insurance Company on April 18, 1997. The state budget also includes the transfers of the central government to the local authorities.

Starting 1997, and in line with greater political autonomy granted to the regions, the state budget excludes all local government budgets. Local government budgets include the budgets of municipalities and 65 local governments: the two autonomous republics of Abkhazia and Adjaria, 10 administrative regions, and 53 administrative districts. Revenues of the local authorities include transfers from the state budget and revenue from their own local taxes.

The two main tax collecting agencies in Georgia are the TIG, which collects most central and local governments domestic taxes, and the State Customs Department (SCD), which collects most taxes and customs duties on imports. Concretely, the SCD collects customs duties and VAT and excises on imports. Payroll taxes are collected by the SSF and EF. The Road Fund collects some small taxes (i.e., the road tax, the vehicle tax, the fuel and lubricants tax). The proceeds from these taxes are earmarked to the construction and maintenance of the road infrastructure. To increase the efficiency of tax collections, the responsibility for the collection of all taxes was to be transferred to the TIG and SCD in 1997. However, the centralization of tax revenue collections under these two agencies has been postponed for the time being due to possible organizational problems in merging the different tax agencies.

\section{Background}

\section{Monetary Sector}

32. The NBG has pursued a prudent monetary policy since the introduction of the lari in October 1995, which has been instrumental in bringing the inflation rate down to single digits per annum and in maintaining a stable exchange rate of the lari. Following the severe hyperinflation of 1993-94, the lari exchange rate has had an important signaling effects in Georgia and its stability has been a key element in the government's reform strategy and the remonetization of the economy. Accordingly, the main objective of the NBG monetary policy has been to stem a depreciation with foreign exchange sales, if necessary, provided such a policy was consistent with maintaining an adequate level of gross international reserves. The

${ }^{8}$ On-lending to the energy sector (from the World Bank and other sources) was projected at US\$46 million, or lari 61 million. 
exchange rate regime adopted by the NBG is a de facto peg of the lari, Georgia's sole legal tender, to the U.S. dollar.

\section{Developments in 1997}

33. The monetary developments during 1997 were characterized by a sharp increase in monetary aggregates, against the background of a stable exchange rate and declining inflation (Figure 6). Broad money (including foreign currency deposits) grew by over 45 percent in 1997 (against an estimated 19 percent increase in the nominal GDP) leading to a 17 percent decline in velocity of circulation of money (Appendix I, Table 26). Reserve money expanded by about 33 percent during 1997, owing in part to a rapid growth of NBG net credit to government in late December (Appendix I, Table 27). ${ }^{9}$ The money multiplier rose by nearly 10 percent during the year, on account of declines on both the currency/deposit ratio and the reserve/deposit ratio, reflecting in part improved confidence in banking sector restructuring (Figure 7). With broad money at 5.5 percent of GDP, however, the level of financial intermediation remained very low. ${ }^{10}$

34. The NBG has continued with its strategy to develop indirect monetary instruments, although the central bank's intervention in the Tbilisi Interbank Currency Exchange (TICEX) remains the main instrument of monetary control. As in previous years, NBG intervention in the TICEX market aimed at sterilizing the liquidity impact of central bank lending to the government, while maintaining an adequate level of reserves. While direct NBG lending to the general government in 1997 remained virtually unchanged relative to the 1996 level, the NBG net sales in TICEX declined sharply to US\$40 million during 1997 compared to about US $\$ 100$ million in 1996, reflecting mainly a significant increase in the demand for real money balances but also a tightening of the NBG credit policy to banks. In 1997, the NBG claims on domestic banks declined by about lari 10 million compared to an increase of about lari 10 million in 1996.

35. Other instruments available to the NBG to influence liquidity conditions include the NBG interventions in the interbank credit auction and the use of banks' reserve requirements. Throughout 1997, the participation of the NBG in the credit auction varied significantly. During the first half of 1997 the NBG continued to provide considerable amounts of credit to

${ }^{9}$ The excess liquidity at end-1997 was sterilized through the sale of foreign exchange by the NBG in early 1998, with reserve money falling to lari 260 million at end-January 1998 compared to lari 277 million at end-December 1997.

${ }^{10}$ In addition to the fact that Georgia was plagued by civil unrest and hyperinflation until early 1994, this unusually low ratio of broad money to GDP could also reflect a possible overestimation of nominal GDP. A recent technical assistance mission by the Fund's Statistics Department recommended substantial methodological improvements in the compilation of the national accounts statistics. 
Figure 6. Prices, Exchange Rates, and Broad Money

(Index January $1994=100$, log scale)

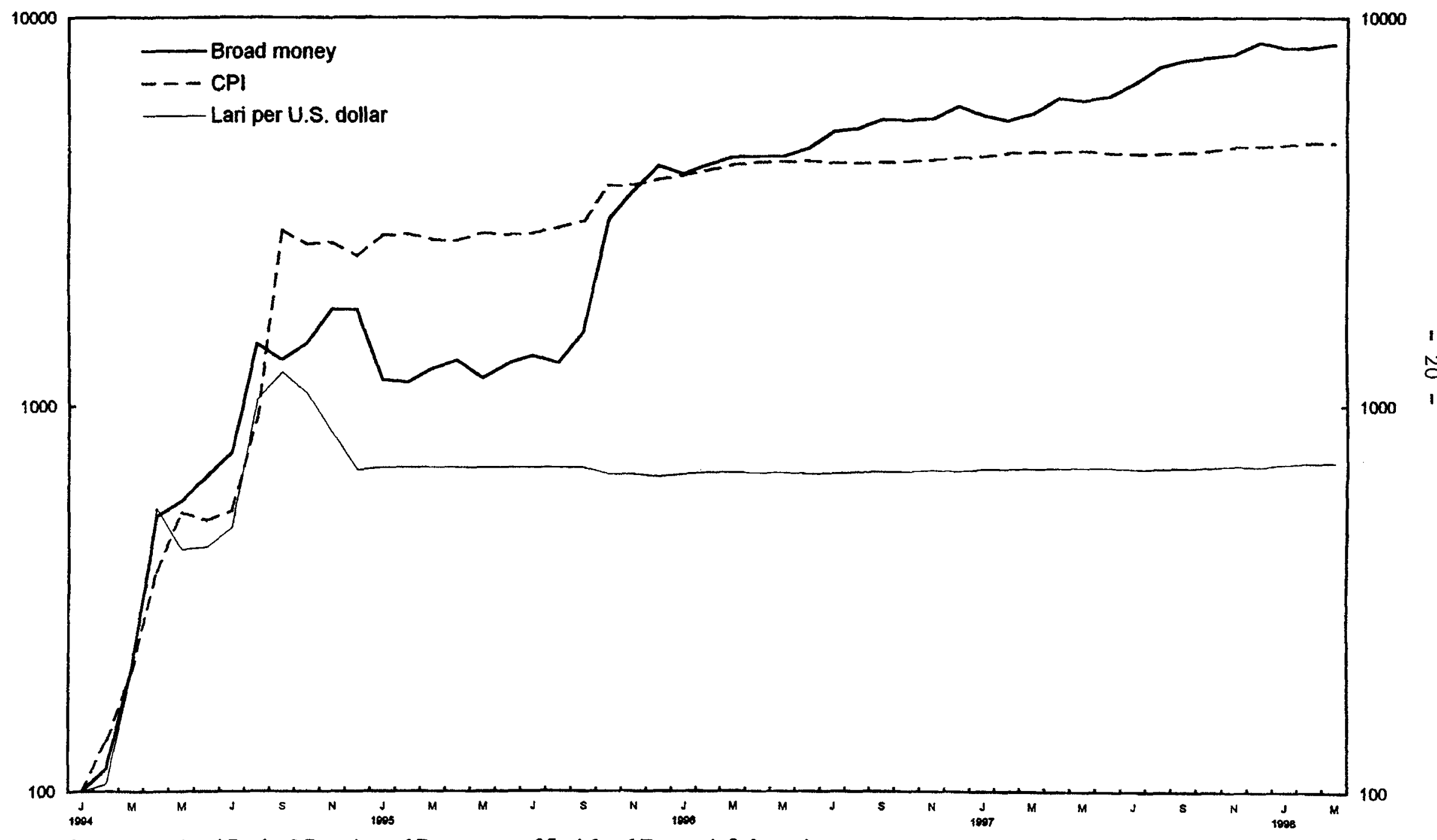

Sources: National Bank of Georgia; and Department of Social and Economic Information. 
Figure 7. Georgia: Currency in Circulation and the Money Multiplier

\section{Currency in Circulaton}

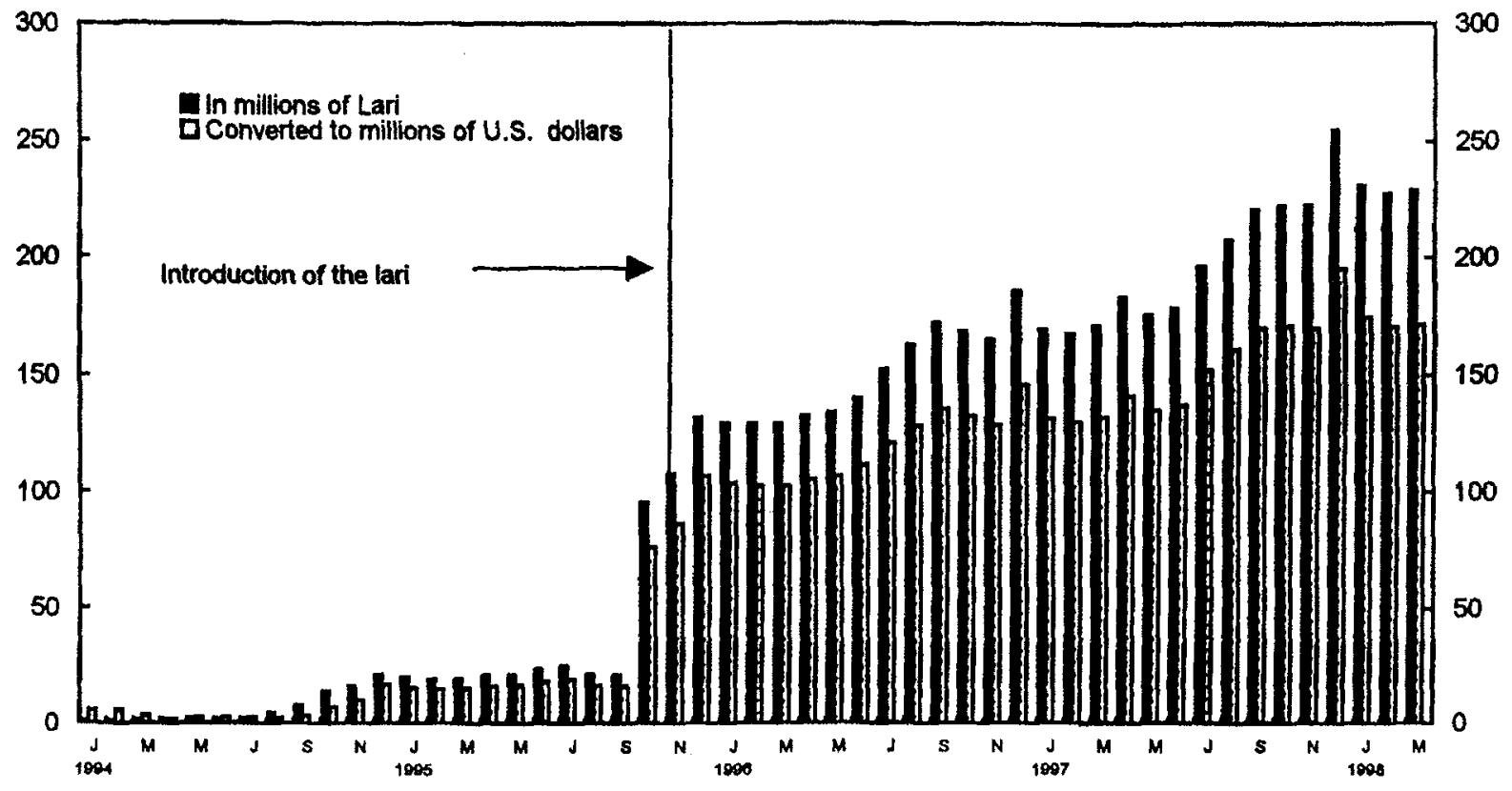

\section{Money Multiplier}

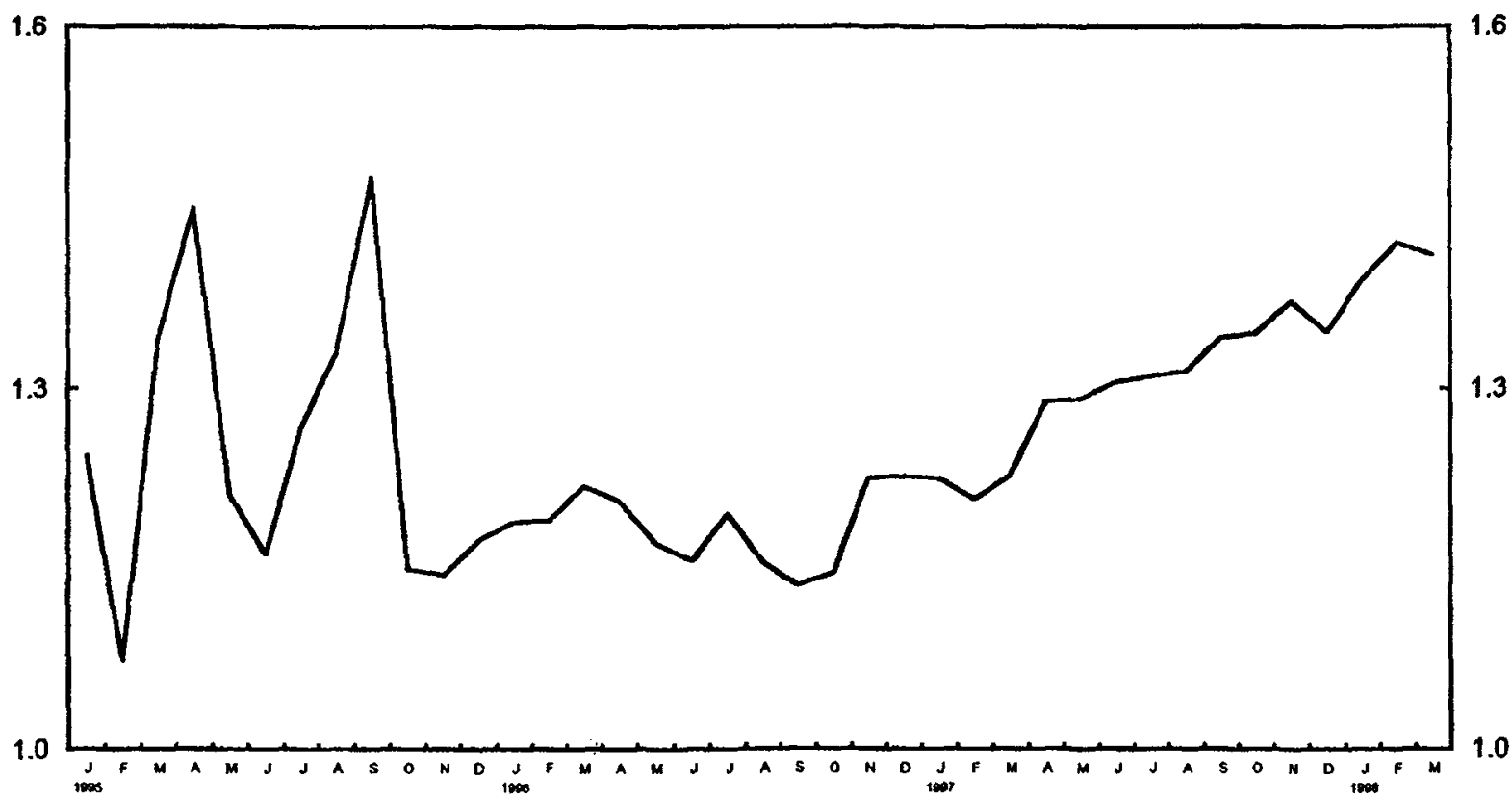

Sources: National Bank of Georgia; and Fund staff estimates. 
banks in an effort to lower banks' lending interest rates. As this strategy was inconsistent with the central bank's reserves target and contributed to increased pressures in the TICEX market, the NBG scaled down significantly its sales in the credit auction market during the second half of 1997, which led to a sharp increase in interest rate levels in that market (Section V). Reserve requirements remained unchanged with respect to 1996 at 12 percent of total deposit liabilities (including foreign exchange deposits).

36. Deposit mobilization and lending to the nongovernment sector by commercial banks continued to increase in 1997. Total deposit liabilities of the banking sector increased by nearly 70 percent during 1997, largely on account of a sharp increase in foreign currency deposits, which more than doubled during the year (Appendix I, Tables 28 and 29). Although the latter contributed to a significant increase in the dollarization ratio, it might also reflect reduced hoarding, together with increased public confidence in the authorities' economic program, in general, and in the banking sector, in particular. While commercial banks' credit to state-owned enterprises remained flat during 1997, banks' lending to the private sector expanded by about 35 percent in nominal terms and financed trade, construction, and the light industry sectors (Appendix I, Table 30). However, by end-1997, banks' outstanding loan portfolio was equivalent to only 2.5 percent of GDP. Reflecting the increase in dollarization, the share of outstanding foreign currency loans relative to total banking sector's loan portfolio increased further to nearly 45 percent by end- 1997 compared to about 35 percent by end1996.

37. Progress with banking sector reform continued during 1997, in tandem with a diminished role of former state banks (FSB) in the financial intermediation process (Box 2). The number of commercial banks declined from 65 at end-1996 to 53 at end-1997, mainly through closures of undercapitalized and insolvent banks, ${ }^{11}$ while the capital base of the banking sector increased by over 65 percent during 1997 relative to its end-1996 level. ${ }^{12}$ By end-1997, all commercial banks had had at least one on-site examination by NBG officials and CAMEL $^{13}$ ratings had been assigned. In general, banks' compliance with the existing prudential regulations continued to improve, although several small- and medium-size banks had, at times, difficulties in meeting reserve requirement and liquidity ratios in 1997. Given the

${ }^{11}$ Given the small households deposit base of the vast majority of banks whose license was revoked and that were ultimately liquidated or are currently under liquidation, the social cost of bank closures has been minimal.

${ }^{12}$ However, banks' average capital remained relatively low at about lari 1.9 million (US\$1.5 million) at end-1997. For the five largest domestic banks, average capital allocations stood at lari 9 million (US\$7 million) by end-1997.

${ }^{13}$ CAMEL (Capital, Assets, Management, Earnings, and Liquidity) ratings of one to five have been used (in decreasing order of financial health). A "five" rating signals the need for liquidation. 
scheduled increase in minimum capital standards through 2000, a further reduction in the number of commercial banks is likely to occur over the coming years. Preparations for the introduction of International Accounting Standards (IAS) by commercial banks continued, but progress in this area is lagging behind, thereby hampering a realistic valuation of the banking sector's financial position. ${ }^{14}$ Georgia's banking sector prudential regulations are broadly in line with BIS norms (Appendix I, Table 31). Banks' short-term external liabilities remained limited at end-1997.

38. The total assets of the FSBs declined from about 40 percent of banking sector's total assets at end-1996 to below 30 percent at end-1997. These trends reflected mainly a faster deposit mobilization by newly-established private commercial banks competing the FSBs and, to a lower extent, FSBs' write offs of outstanding nonperforming loans. Foreign participation in Georgia's banking sector albeit on the rise remains limited. By end-1997, only two foreign banks (one Russian and another Turkish) were operating in Georgia, probably reflecting the small size of Georgia's financial market, although one third of banking sector total capital was reportedly foreign-owned. ${ }^{15}$

39. Following the decline in inflation and the progress made in banking sector restructuring, the overall level of nominal interest rates has fallen and the spread between banks' deposit and lending rates has narrowed considerably (Appendix I, Table 32). The three-month average deposit and lending rates declined to about 13 percent and 45 percent, respectively, at end-1997 compared to about 16 percent and 53 percent, respectively, at end1996. Despite the interest rate fall during the last couple of years, interest rate spreads remained high, amounting to some $25-30$ percentage points at end-1997. These spreads appeared to be related mainly to a severe credit rationing given the extremely low deposit base relative to GDP, combined with significant overheads (fixed costs) and slow progress in enterprise and judicial reform. The latter factor makes the preparation of adequate loan risk analysis very difficult, and the seizure of delinquent borrowers' assets an almost impossible task for banks.

${ }^{14}$ According to the NBG, non-performing assets of the banking sector accounted to 6 percent of total outstanding loans at end-1997. Measurement problems (due to inadequate accounting practices) may limit the accuracy of these indicators, however.

${ }^{15}$ Most of the foreign participation in the domestic banking industry reflects injections (by foreign firms and individuals operating in Georgia) into existing Georgian banks before end1996. A main factor explaining these capital injections was the tax holiday for foreign investments in the domestic banking system (in place through end-1996) and the expectation of lucrative insider lending to equity holders. 


\section{Box 2. A Chronology of Banking Sector Reform in Georgia}

1994: Prudential regulations. Effective February, the NBG doubled banks' minimum capital requirements to coupon 400 million (US\$2,000). It also introduced a moratorium on the licensing of new banks and stepped up the enforcement of prudential regulations, including the introduction of steep penalties ( 0.5 percent a day, compounded fine for shortfall on required reserves) and the repeal of bank licenses for extended noncompliance with prudential requirements.

Monetary policy. Automatic commercial banks' overdraft with the NBG was eliminated at end-1994.

1995: Prudential regulations. Prudential requirements were strengthened in January and May, including: (i) an increase of capital to asset ratio requirement from 5 percent to 8 percent; (ii) an increase of minimum capital requirements to US\$100,000; (iii) a reduction in the limit on banks' lending to any single borrower from 50 percent to 10 percent; and (iv) the introduction of a limit on total lending to insiders equivalent to 100 percent of paid-in capital. A bank certification program started in November 1995. Before certification, banks were prohibited to distribute dividends or on-lend any foreign credits. By end-1995, the number of banks whose licenses were withdrawn amounted to 99 , reducing the number of domestic banks in operation to about 130 .

Restructuring and privatization of former state-owned banks (FSBs). In May 1995, three (out of five) FSBs were merged to create the United Georgian Bank (UGB). In less than a year, UGB laid off 3,300 of its staff (about 60 percent of total staff).

Legal framework. In June 1995 a new NBG law was adopted. The law provided for the independence of the central bank and established price and exchange rate stability as the primary objective of the NBG.

Monetary Instruments. Credit auctions were introduced in May 1995. Banks could use up to 75 percent of their reserve requirements as collateral for borrowing in this market.

1996: Prudential regulations. Effective January, reserve requirements were to be paid 100 percent in lari, including for foreign currency deposits. Reserve requirements were reduced from 20 percent to 18 percent in June 1996 and further to 15 percent in September.

Effective June, the limit on banks' households deposit mobilization increased from 100 percent to 200 percent of paid-in capital for certified banks.

Effective September, the NBG tightened further the regulations on bad-loans provisioning.

Commercial bank restructuring. In April, the NBG signed bilateral agreements with the FSBs, freezing their asset growth until they complied fully with existing prudential regulations. The privatization of FSBs was completed in the second half of 1996 . In addition, the number of commercial banks operating in Georgia by end-1996 had declined to 65 , of which 45 banks had been certified by the NBG.

Legal framework. The NBG law was amended in April to make it consistent with the Constitution. Also, a new commercial banking law was adopted, which, inter alia, strengthened NBG authority to liquidate undercapitalized and/or insolvent banks. A bankruptcy law was adopted by parliament in September.

Monetary instruments. Effective January: (i) the frequency of interbank auctions increased from weekly to bi-weekly sessions; (ii) credit auctions with a maturities of one-month and three-months were introduced to complement auctions with a maturity of seven-days; and (iii) the share of reserve requirements that could be used as collateral in credit auctions was increased from 75 percent of reserve requirements to 90 percent.

1997: Prudential regulations. Effective January: (i) reserve requirements were lowered from 15 percent to 12 percent; (ii) the limit on households deposit mobilization was raised to 900 percent of paid-in capital; (iii) the capital adequacy ratio was also raised from 8 percent to 10 percent of total assets; and (iv) the limit on insider lending was reduced from 100 percent to 50 percent of paid-in capital.

In December, the NBG announced a schedule for a step-by-step increase of banks' minimum capital requirements to lari 5 million by end-2000 (compared to lari 0.2 million at end-1997).

Bank restructuring. Two of the three FSBs, the UGB and BG, were certified in August and July, respectively. As a result of the bank certification program, the number of commercial banks operating in Georgia at end-1997 declined to about 53, of which 47 were certified by the NBG. As of end-1997 Georgia did not have a deposit insurance scheme in place.

Monetary instruments. In August, sales of treasury bills were introduced and the NBG issued regulations on the establishment of a lombard facility. 


\section{External Sector}

\section{Balance of payments}

40. The current account deficit (excluding transfers) widened from 9 percent of GDP in 1996 to 10 percent in 1997 (Appendix I, Table 33). ${ }^{16}$ While the data on trade flows are still subject to a wide margin of error, ${ }^{17}$ they do suggest that exports and imports, in particular, grew markedly in 1997.

41. Total merchandise exports increased by an estimated 11 percent in nominal terms in 1997, following a growth rate of 15 percent in 1996. As a share of GDP, exports increased slightly from 11 percent to 12 percent. While reliable data on the breakdown of exports are not available, trade data recorded by customs indicate that export growth in 1997 was driven mainly by beverages, spirits, and vinegar, iron and steel, and related products. These items accounted for almost 40 percent of total recorded exports and grew in nominal terms by almost 90 percent in 1997.

42. Total merchandise imports increased by 23 percent in nominal terms in 1997, after an equivalent 10 percent growth in 1996. As a share of GDP, imports increased from 19 percent to 23 percent in 1997 . The large increase was driven mainly by imports associated with the construction and refurbishment of the "early oil" pipeline connecting Azerbaijan to the Black Sea, which increased by almost five fold in volume terms. Natural gas imports in 1997 totaled about an estimated one billion cubic meters (i.e., a decline of seven percent from the previous year). Imports of wheat and flour (about 10 percent of total imports) fell sharply in 1997 by about 50 percent in nominal terms, reflecting the record grain harvest (Section II A).

43. During 1997 , the deficit in overall services improved slightly to US\$51 million, although the factor and nonfactor balances shifted dramatically between 1996 and $1997 .^{18}$ Transportation costs and costs associated with business travel accounted for most of the debt in nonfactor services. Of the US\$99 million in factor income credits, almost all was due to compensation of short-term Georgian residents working abroad. The remainder

(US\$6 million) represented interest income earned on Georgia's holding of foreign exchange

${ }^{16}$ In 1997 with the assistance from the Fund's BOP technical advisor, the collection of balance of payments statistics has improved, particularly regarding the adjustments for unrecorded trade arising from smuggling and in the coverage of the nonfactor services. However, despite these improvements, exports and imports are still likely underestimated.

${ }^{17}$ As a result of the significant changes in the coverage of the trade data for 1997 , caution is needed in assessing the change from 1996 to 1997.

${ }^{18}$ As with the trade data, improvements in the collection of service data in 1997 make it difficult to compare the change in the services account between 1996 and 1997. 
reserves. On the debit side, the Georgia's payment of US\$32 million to the special account at the Netherlands Bank for interest on rescheduled debt accounted for almost three-quarters of Georgia's scheduled interest payments (US $\$ 44$ million), with the remaining for interest payments to multilaterals and new bilateral lending.

44. According to the official trade data for 1997, Russia, Turkey and Azerbaijan were Georgia's three largest trading partners (Appendix I, Table 34). Russia was the largest market of Georgia's exports ( 30 percent), followed by Turkey (13 percent), and Azerbaijan (11 percent). ${ }^{19}$ On the import side, Russian imports made up 13 percent of total recorded imports, followed by Azerbaijan and Turkey (both at 12 percent).

45. Transfers (including private transfers) totaled US $\$ 188$ million in 1997. Of the total, US\$84 million were official transfers, with the U.S., the EU, and various NGOs being the largest contributors. Private transfers consisted mainly of remittances from Georgians working abroad.

46. The capital account registered a major improvement over 1996, mainly on account of the surge in foreign direct investment related to the construction and refurbishment of the Georgian portion of the oil pipeline connecting Sanachal in Azerbaijan and Supsa in Georgia. Work on the pipeline began in February 1997 with construction picking up strongly in the second half of the year. Investment in the oil pipeline was estimated to be around US\$65 million in 1997, which in addition to the investment in 1996, represented about 45 percent of the estimated total cost (US\$180 million). The pipeline project is expected to be finished in late 1998. Although the data are preliminary, other non-pipeline related foreign investment in 1997 was estimated to be around US\$140 million.

47. Due to the grace period provided under Georgia's rescheduling agreements with bilateral creditors, Georgia made only minor amortization payments in 1997, in particular to Germany and the EBRD. The remaining principal payments falling due to Turkey were rescheduled. In addition, the EU and Georgia signed in December 1997 a loan agreement to provide exceptional financial assistance to settle Georgia's outstanding obligations to the EU. Disbursements grew by 15 percent from 1996 to 1997, largely on account of increased lending from the EBRD and bilaterals. Disbursements from bilateral creditors (Germany, Japan, and the U.S.) grew from US\$26 million to US\$36 million in 1997. EBRD lending, mainly in the areas of energy, banking and finance, is estimated to have reached US\$16 million. In 1997, several new IDA projects were approved including those for Agriculture Development, Oil Institutions Building, Power Rehabilitation, and a Social Investment Fund. In addition, the World Bank disbursed US $\$ 40$ million in November 1997 as the first tranche under its SAC II program. Overall, the World Bank remained one of Georgia's largest creditors in 1997 with disbursements totaling about US\$71 million in 1997.

${ }^{19}$ Due to the large incidence of smuggling, the actual export share for Azerbaijan, Russia, and Turkey are likely to be higher than the official figures. 
48. Georgia received two disbursement under the second year ESAF arrangement in April and October 1997 totaling US\$76 million. Exceptional financing amounted to US\$41 million resulting from arrears and debt-rescheduling agreements with Russia, China, the EU, and Turkey. As a result, gross official reserves increased by US\$15 million in 1997 after remaining virtually unchanged in 1996 . However, in terms of import coverage, gross official reserves declined from 2.5 months of imports in 1996 to 2.2 months in 1997.

\section{External debt}

49. At the end of 1997, Georgia's total stock of external debt reached US\$1,539 million, virtually all is publicly contracted or guaranteed (Appendix I, Table 35). While the total stock of external debt increased in 1997, as a share of GDP, external debt declined slightly to about 29 percent. Multilateral creditors, including the Fund, make up about 34 percent of the entire stock. Of the remaining debt to bilateral creditors, the largest single creditor was Turkmenistan, accounting for almost one-quarter of Georgia's entire stock of external debt. All of Georgia's external debt can be classified as medium-and long-term debt. Following rescheduling agreements reached with official creditors in 1996, Georgia's debt-service payments in 1997 reached US\$54 million (an estimated 9 percent of exports of goods and nonfactor services). For the year, Georgia continued making its US\$8 million quarterly payment into a special account at the Netherlands Bank to demonstrate its willingness to conclude rescheduling negotiations. Debt service to multilaterals amounted to US\$10 million and the remaining was on account of payments for new (i.e., post 1994) bilateral lending (US\$10.2 million) and private commercial borrowing (US\$1.6 million) (Appendix I, Table 36).

50. Georgia signed rescheduling agreements on pre-1995 bilateral debt with a number of official creditors in 1997 and early 1998. ${ }^{20}$ In February 1997, Azerbaijan agreed to restructure Georgia's debt with an interest rate of 4 percent, 7 years grace period, and 12 years maturity from end-1994. Also in February, Ukraine granted Georgia rescheduling terms of an interest rate of 4 percent, 5 years grace period and 10 years maturity. More recently in December 1997, China and Georgia agreed to rescheduling terms of an interest rate of 4 percent, 5 years grace, and 10 years maturity. In February 1998, Turkey agreed to reschedule its stock of debt valued at US\$54 million with an interest rate of 4 percent, 7 years grace from end-1994 and 16 year maturity. As a result of the agreement with Turkey, Georgia has now concluded its round of debt rescheduling with bilateral creditors. ${ }^{21}$

\footnotetext{
${ }^{20}$ Previous debt-rescheduling agreements on Georgia's pre-1995 bilateral debt are described in EBS/97/29 and SM/97/71.

${ }^{21}$ There are outstanding correspondent accounts balances with other BRO countries, however, accumulated during 1992-94 on which negotiations are still ongoing.
} 


\section{Exchange rate and exchange system developments}

51. The nominal exchange rate vis-à-vis the U.S. dollar remained fairly stable throughout 1997. The end-of-period lari/U.S. dollar exchange rate depreciated by 1.8 percent in 1997 , from lari/US\$1.28 to 1.304 (Appendix I, Table 37). However, against other major currencies, the lari appreciated in nominal terms-by 85 percent against the Turkish lira, 11 percent against the Armenian dram, and 5 percent against the Russian ruble (Figure 8). Against the Azeri manat, the lari depreciated by about 10 percent. As a result, the nominal effective exchange rate, which measures the lari against a basket of trading partner currencies, appreciated by 15 percent term in $1997 .^{22}$

52. In real terms, the Georgian lari appreciated by 3.0 percent against the U.S. dollar, 2.1 percent against the Russian ruble, and 1.7 percent against the Turkish lira. Against the Azeri manat, the lari depreciated by about 5 percent in real terms. Despite the continued decline in inflation, the lari is estimated to have appreciated in real effective terms by around 3 percent in 1997, following a real effective appreciation of 6 percent in 1996.

\section{Trade policy}

53. Georgia still maintains one of the most liberal and open trade systems among the BRO countries. With the introduction of a second tariff band of 5 percent in January 1997, Georgia currently maintains a two-tier tariff regime ( 5 and 12 percent). The import-weighted average tariff rate in 1997 is estimated to be 3.9 percent. $^{23}$ In addition, Georgia has applied for accession to the World Trade Organization (WTO) with the hopes of becoming a member in 1999. ${ }^{24}$ A new customs law, developed in cooperation with the World Bank staff, became effective in March 1998 (Box 3).

\section{Box 3. Changes to the Customs Law}

On March 29, 1998, a new Law on Customs Duty came in effect. A major change in the new law was to. eliminate the reference pricing system for customs valuation. For the purpose of taxation, the custom value of the good will now be determined according to its contract value. The new law maintains the existing custom duty rates of 5 and 12 percent, but introduces a number of new exemptions. They include: import of property of foreign diplomatic agencies, baby hygienic products, raw materials, half-finished products, and packing materials for export goods production within the volume of the exported finished product. The new law also stipulated that commodities produced and imported from CIS countries excluding light cars and oil products to exempt from custom duties until April 15, 1998. Oil products from CIS countries will be taxed at 12 percent.

${ }^{22}$ These calculations were done using the official weights for Georgia's trading partners in 1997 (Appendix I, Table 34).

${ }^{23}$ Official estimate.

${ }^{24}$ Section VI for an update on the status of Georgia's application to the WTO. 
Figure 8. Georgia: Bilateral Nominal and Real Effective Exchange Rates (1995 = 100)

Nominal Bilateral and Effective Exchange Rates

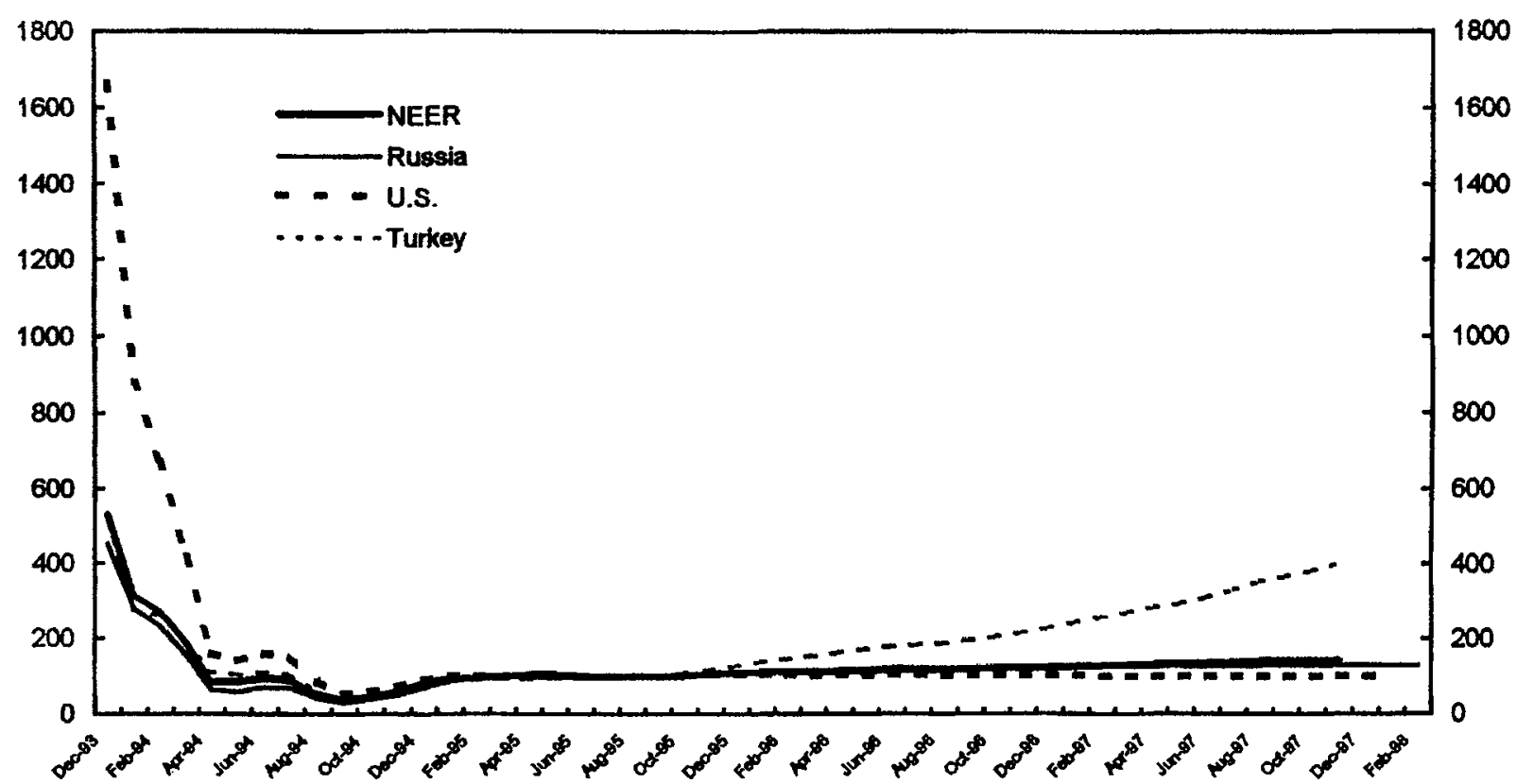

Real Bilateral and Effective Exchange Rates

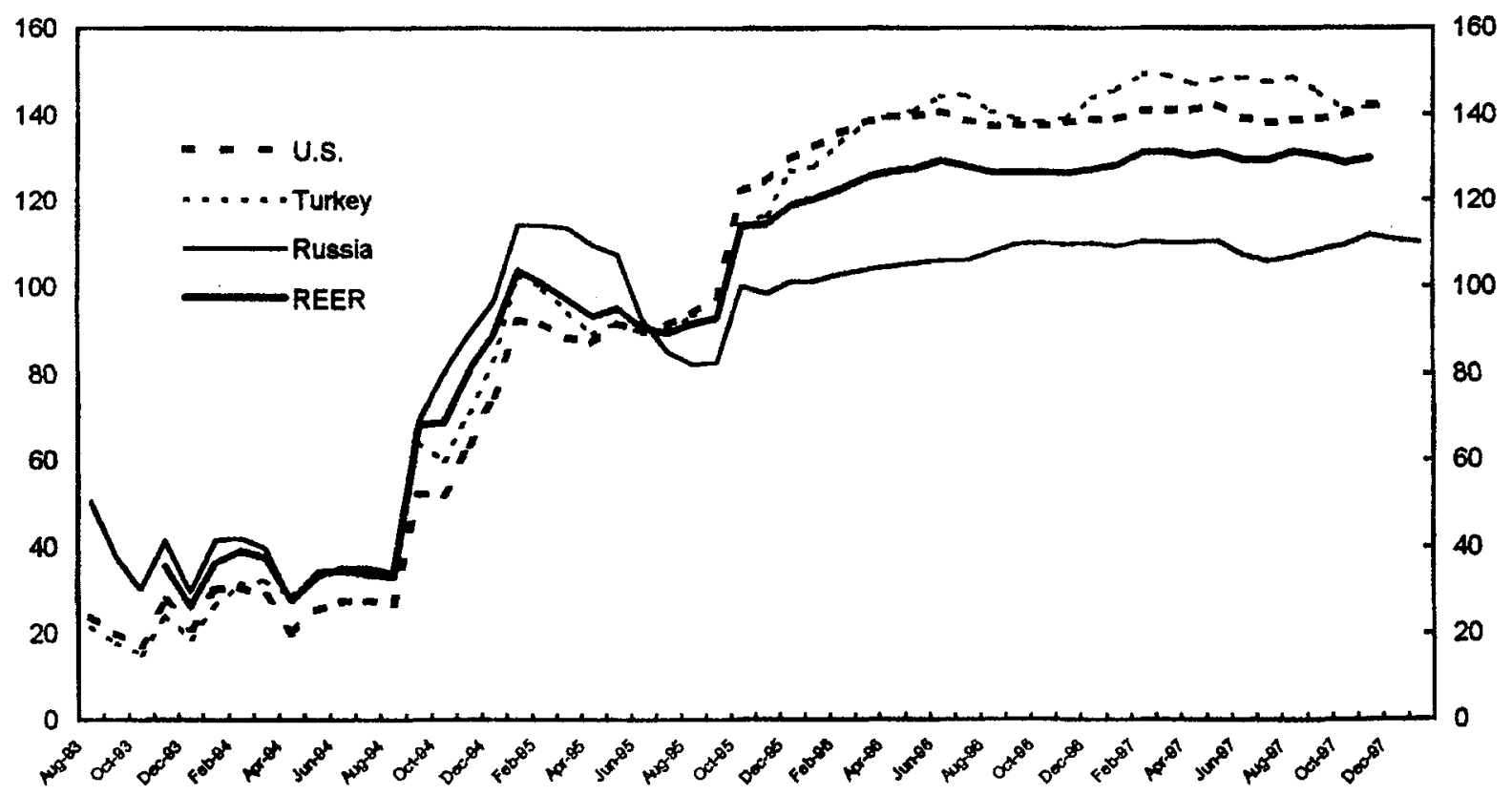

Sources: Fund staff estimates. 
54. While Georgia remains free of restrictive licensing requirements and quantitative restrictions on imports, an export ban on scrap metal remained in place through end-1997. ${ }^{25}$

\section{E. Structural Policies}

55. Important progress was made on the structural front during 1997. The pace of privatization accelerated during the second half of the year, further progress was made in the agricultural land reform, and the authorities passed various laws-notably a new tax code, a civil code, and a law on bankruptcy - and advancing the development toward a market economy. Despite progress in energy sector, the sector continued to be plagued by severe financial difficulties.

56. Privatization of small-scale enterprises is now virtually complete. By end-1997, about 10,000 enterprises were privatized, up from 1,657 in October 1994, and 6,700 in February 1996. Transfers of ownership of medium-size and large-scale enterprises started in 1995 through various methods, mainly buy out options to employees and employers, and a mass privatization program offering at least 35 percent of shares through voucher auctions. Following a relatively quick start, the privatization of medium- and large-scale enterprises slowed down considerably after the expiration of voucher privatization in July 30,1996. The main reason for that was the adoption of minimum prices for enterprises shares offered in auctions, which in some cases were over 20 times higher than the actual price paid during the voucher privatization. As a result, the number of privatized medium- and large-scale enterprises remained virtually unchanged at about 520 enterprises through end-June 1997. To speed up the privatization process, the authorities organized a zero-price auction in July 1997 and were able to privatize over 270 medium-scale enterprises during July 1997. In addition, to privatize the rest of enterprises the government developed a new privatization strategy, which distinguished between the groups of enterprises. The first group (group A) comprises the large enterprises, which are primarily engaged in heavy industry (e.g., chemicals, metallurgy, mining). These enterprises-which also include those in the energy sector-cannot operate without significant restructuring and new investment. Their size and technology require privatization to strategic investors on a case-by-case basis, investment tenders, or some other methods such as leasing. The second group (group B) includes the smaller-and more numerous - enterprises, which are likely to have a larger proportion of assets, which could be easily redeployed. Group B consist of 413 enterprises while group A comprises 103 enterprises. Through these different steps, it is expected that by mid-1998, over 900 out of the 1,043 medium-size and large-enterprises will have been privatized. If some of the proposed sales to strategic investors are successful, this number could increase even further.

57. Agricultural land privatization, which started in 1992, made further progress with distribution of about 60 percent of cultivated land to private farmers by end-1997. In 1996,

\footnotetext{
${ }^{25} \mathrm{~A}$ registration fee on the export of logs of lari 60 per cubic meter was introduced in March 1998.
} 
three far-reaching laws (laws on private ownership, titling and registration, and leasing) were adopted providing the legal basis for the functioning of a land market in the agriculture sector. The next steps in the development of an efficient market for land will be the introduction of an adequate titling and registration system. The World Bank is providing assistance for the setting of cadastres in two districts.

\section{Electricity sector restructuring}

58. Energy sector reform in 1997 included the enactment of the Electricity Law, increases in electricity tariffs, and further work in developing a strategy for privatization of the power sector. The Electricity Law approved by the parliament and signed by the president in June 1997, separated the policy, regulatory, and ownership function of the government, disengaged the government from business operations, and established an independent electricity regulatory commission with authority to approve energy tariffs and issue, enforce, and revoke licenses for activities in the sector. The law did not prescribe a specific industry structure, but is based on a broad consensus that following restructuring and unbundling, the industry would have multiple participants, particularly at the stage of electricity generation and distribution.

59. Payment collections of electricity bills, although still low, increased steadily during 1996 and 1997, reaching the average level of about 62 percent at the retail level, compared with less than 20 percent in 1995. In August 1997, the government approved an increase of 36 percent in residential tariffs to reach the same tariff level charged to other retail consumers, including industry. Average wholesale prices for generation and sales from Sakenergo to distribution companies were also increased in September 1997. In spite of the above mentioned actions, however, substantial increases in electricity tariffs and improvements in collections and losses would be necessary to have financially viable power utilities. Retail tariffs do not cover full costs, technical losses are high, and collections are low; in consequence, revenues are not sufficient to cover operations and maintenance needs let alone make a contribution to rehabilitiation of the network. This generates a chain of nonpayments and poor service. ${ }^{26}$

60. During 1997, the Georgian government continued to work toward the development of a privatization strategy of the power sector. The strategy will update and revise the Presidential Decree No. 828 of December 19, 1996. Most power sector enterprises are being considered for privatization, although transmission and dispatch (Sakenergo), sector enterprises in Abkhazia, and leased enterprises are currently excluded from the process. Preliminary analysis suggests that the government should start with privatizing the distribution

\footnotetext{
${ }^{26}$ Distribution companies cannot and do not pay on time for wholesale power purchase to Sakenergo (60 percent collections during first semester of 1997), Sakenergo cannot pay to generators and fuel suppliers, needed repairs and fuel supply for generation cannot be funded, and supply cannot meet demand (by some accounts, about 40 percent of demand is rationed).
} 
companies, as these would likely produce the greatest immediate benefits for consumers, and face fewer risks and unresolved issues than generation. Moreover, an improvement in collections, which can only begin at the distribution level, would enhance the privatization prospects of the whole sector. Telasi (Tbilisi Distribution Company) is an obvious candidate for the first privatization as the largest and most prominent distribution company.

\section{BUSINESS ENVIRONMENT AND FOREIGN DIRECT INVESTMENT IN GEORGIA}

\section{Introduction}

61. The business environment in Georgia can be characterized as difficult, but improving. The economy has grown over 10 percent per year in 1996 and 1997, as a result of the economic stabilization that began in 1994. Nevertheless, significant weaknesses remain in the business environment which need to be addressed for sustained economic growth over the medium term. As in other transition economies, key determinants of the Georgian business environment are (and will be) the evolving role of the government and the rule of law in the economy: two variables that still need to be further strengthened in Georgia.

62. This section briefly summarizes Georgia's initial conditions for private sector development, some reported weaknesses with the implementation of legislation required for a market economy, and the recent trends with foreign direct investment.

\section{Initial conditions}

63. During the last three years, Georgia has established sound macroeconomic and structural reform policies which, combined with Georgia's relatively well educated labor force, are supportive of private business. On the macroeconomic side, the lari has remained stable against the U.S. dollar since its introduction in September 1995, and is not subject to exchange restrictions. Inflation has declined to 7 percent during 1997, down from a high of 50,000 percent in the 12 months to September 1994 . Nearly all prices have been liberalized. Although government revenue has increased sharply to 10 percent of GDP, and the amounting external debt has largely been rescheduled, the levels of revenue and debt pose problems for the sustainability of macroeconomic stabilization in the medium term. The government is aware of these challenges and has been actively working with the international financial institutions to overcome this situation in the nearest future.

64. Georgia also possesses a liberal international trade policy. A low, uniform customs tariff of 12 percent is applied to almost all imports, with the exception of some goods which are taxed at 5 percent or are exempt. The state order system and hard currency surrender requirement were eliminated in 1995, and no export prohibitions remain in place except for scrap metal. A system of bonded customs warehouses has been developed, and a duty 
drawback scheme is under development. Proposals for free economic zones have not moved forward due to concerns about the loss of tax revenue.

65. Political stability has also improved significantly. Under President Shevardnadze's leadership, the government has restored law and order, and held elections for the Presidency and parliament under a new Constitution. The first local government elections are planned for 1998. The violent conflicts in Abkhazia and South Ossetia have subsided for several years, but a final resolution has not yet been reached. Moreover, while the autonomous region of Adjara acknowledges the rule of national government, it exercises considerable independence in practice.

66. On the structural side, the Georgian authorities have been implementing a farreaching program to set the basis of a market economy. Privatization of large-scale enterprises has just begun in Georgia, but small- and medium-scale privatization in Georgia is largely complete. The government recognizes the need to improve infrastructure and has announced its intention to privatize key assets. The first step in this direction will be the privatization in 1998 of the Tbilisi electricity distribution company, Telasi, through a foreign investment bank. Agricultural land privatization is almost complete, although an active land market has not yet emerged as a result of the lack of progress in land registration. The legal framework for private ownership of urban and industrial land does not yet exist, although the buildings on it can be purchased, and the land can be leased from municipalities. Municipal leases are not allocated in a transparent manner through an open tender, and are generally seen to be underpriced. A law to permit private ownership of urban and industrial land is expected in 1998.

67. As in many CIS countries, however, much of the progress in macroeconomic stabilization and structural reform still needs to be complemented with large investments in public utilities and further institution building needed for private sector development. For example, the quality of Georgia's infrastructure, after years of deterioration, poses a serious obstacle to economic development, despite some improvement in the past two years.

Electricity is supplied only according to a limited schedule, and is subject to cutoffs and voltage fluctuation which can damage expensive equipment, particularly during the winter months when electricity is generated by burning imported natural gas and heating oil rather than from hydropower. Almost all enterprises must use generators at times, requiring them to buy oil products from another state-owned monopoly, now slated for privatization. The stateowned telecommunications and postal service monopolies provides inadequate service. Although a number of telephone exchanges in major cities have been upgraded with foreign equipment, line quality is poor, wrong numbers are common, and disconnection of paying customers is not unusual. These problems have promoted the development of three cellular telephone systems, which provide better service but at a significantly higher cost. The licenses for these systems were apparently not distributed in a transparent manner, and the regulatory framework remains unstable. Transport infrastructure has improved in the last three years. Trunk roads now receive some minimal maintenance, and a cross-country journey by a truck, 
impossible before the restoration of law and order in the last few years, now entails a more reasonable level of delays and costs. The main rail route to Russia, through Abkhazia, remains cut, but the railway have been able to provide adequate service for pipeline rehabilitation, oil exports, and transit trade. Container traffic through Poti and Batumi ports is doubling each year and the Tbilisi airport has been rehabilitated with European Bank for Reconstruction and Development (EBRD) financing, and is now served by four international airlines.

68. Financial sector development is another major challenge for the Georgian authorities. The primary sources for financing investment are retained earnings, informal intermediation outside the banking system, and foreign direct investment. Commercial bank loans to the private sector amounted to only 2.5 percent of GDP at the end of 1997, with interest rates of 40-50 percent per annum compared with single-digit annual inflation rates. Furthermore, short-term trade loans account for most lending, although some longer-terms loans are available through foreign official credit lines. Lending practices are poorly developed; and the allocation of loans are not always based on purely economic criteria.

\section{Regulatory framework and its implementation}

69. Georgia has enacted the basic legal framework for a market economy (Box 4). The Civil Code and other business laws are in place and market competition is becoming the economy's rule, as the privatization of land and enterprises takes hold.

70. The Georgian legal framework, however, is not always well enforced. For instance, assessments by tax and/or customs officials are many times not made in a transparent manner. Also, many businesses have found that tax authorities are able to obtain information about their commercial bank accounts and freeze them or deduct funds without a court order, preventing normal business operations. The legal framework in this area is contradictory and changing over time. A court order is required before a commercial bank discloses information to tax authorities according to Article 17 of the Law on Commercial Banks. However, this law's provisions on secrecy are undermined by Article 233 of the Tax Code, which requires that commercial banks notify the Tax Inspectorate of new accounts, and execute payments only if the recipient's and sender's Tax Identification Numbers are attached. ${ }^{27}$ Another source of authority is the NBG regulation on non-cash settlements, approved in September 1996, which orders commercial banks to execute tax inspector's requests to deduct funds from a taxpayer's account

71. Difficulties in implementing laws are not limited to the area of taxation. A bankruptcy law was enacted in 1996, but has not yet had a significant impact, in part as a result of slow

\footnotetext{
${ }^{27}$ The Tax Inspectorate attributes its authority to freeze banks accounts to Article 245 of the Tax Code, which refers to seizure of property based upon a court order. In some cases it has cited Article 265(e), which refers to the right of the Tax Inspectorate to collect taxes not paid in a timely manner, but does not mention bank accounts or court orders.
} 
decision-making by courts, and poorly defined trigger conditions for bankruptcy. The law was modified in 1997 so that bankruptcy can be triggered by any unpaid obligation, rather than the condition that liabilities are greater than assets. To date, the Tax Inspectorate has submitted 120 bankruptcy cases to the court. Of these, 14 have been considered, all of which were reorganizations rather than liquidations.

\section{An anti-monopoly law was enacted in 1996, but the enforcement agency lacks} sufficient power to ensure competition. In practice, many potentially competitive markets are monopolistic, for instance, the import of oil products is a state-owned monopoly (now being privatized), and privately-owned firms appear able to resist entry into some consumer product markets.

\section{Box 4. Legal Framework for Private Sector Development}

Tax Code (June 1997): The Tax Code applies stable, uniform rates of taxation with a limited number of exemptions. The rate of profit tax is 20 percent, the VAT is 20 percent, payroll taxes add up to 33 percent, and the personal income $\operatorname{tax} 20$ percent. It also specifies the structure and powers of the Tax Inspectorate. The code implemented the invoice credit method of collecting VAT.

Law on Customs Tariffs (March 1998): The law establishes a stable, uniform customs tariff of 12 percent on imports, with a rate of 5 percent for certain raw materials, and with a limited number of exemptions. The new law brought the existing tariff structure in line with the Harmonized System.

Customs Code (November 1997): The code provides the legal basis for the customs administration. The code specifies the structure and powers of the State Customs Department, as well as procedures for clearing goods and for transit.

Law on Commercial Banks (February 1996): The law, along with the Law on the NBG, creates a two-tier banking structure, under which the NBG has authority to license and to supervise commercial banks. The law specifies the permissible activities of banks, ownership restrictions, accounting and auditing requirements, and procedures for temporary administration and liquidation.

Law on Privatization (May 1997): The law determines procedures for privatization, including voucher auctions, cash auctions, tenders, and lease-to-buy arrangements. Only a limited range of state assets are not subject to privatization, including electricity transmission and dispatch, harbors, railways, gas pipelines, motor-ways, security-related properties, and telecommunications; this list may be reduced during 1998.

Law on Entrepreneurs (October 1994): This law specifies the permissible organization forms for enterprises, including an individual enterprise, a joint liability company, a limited partnership, a limited liability company, and jointstock company, and a cooperative. The law required the reregistration of enterprises through the court system. It specifies requirements for accounting and audit; it does not require independent share registries.

Civil Code (June 1997): The Civil Code provides a modem basis for civil law, including the resolution of commercial contractual disputes.

Law on Monopoly Activity and Competition (June 1996): The law created an antimonopoly service to investigate anti-competitive practices and to prescribe remedial measures.

Law on Bankruptcy (June 1997): The law determines the trigger conditions for bankruptcy and procedures for the liquidation of bankrupt firms. Because the trigger condition that liabilities exceed assets proved ineffective in practice, the law was modified in 1997 so that non-payment of debt triggers bankruptcy.

Law on Agricultural Land Ownership, Registration, and Leasing (1997): These three laws provide the legal basis for the private use of agricultural land. They provide the basis for distributing agricultural land to farmers, create transferable property rights for privately owned or leased land, and a land registration system. 
73. Businesses report that enforcement of contracts is weak, and do not rely on the courts for the resolution of disputes. There are several causes. First, judges are often poorly trained and paid. Businessmen report losing significant sums of money or even their entire business as a result of court decisions that appeared based upon influence rather than legal considerations. Second, judgments are often not enforced properly. A judicial reform program is underway, with assistance from the World Bank, to test judges, raise their salaries, and improve the enforcement of decisions.

74. Patronage rather than superior management appears to be the key to success in many sectors, given the weak legal framework and broad discretion of officials. Firms with official connections are more able to avoid taxes, especially importers of cigarettes, alcohol, oil products, cars, and flour, and manufacturers of consumer products. Official connections can also help borrowers obtain access to credit and it is not unusual for government departments to operate businesses in areas which they regulate, including, for instance, competitive markets such as cellular communications and taxis.

\section{Foreign direct investment}

75. Despite a weak implementation of the current legal framework, criticism on the way fiscal and other legislation are actually applied should be viewed in context. First, a recent survey of the largest investors shows that actual foreign direct investment inflows into Georgia increased from approximately US\$54 million in 1996 to at least US\$189 million in 1997 (Text Table 1). This level of investment in 1997 was three times higher than projected, and at US\$38 per capita or 3.8 percent of GDP is well above the average for other members of the CIS (in 1996). Two-thirds of the investment is not part of the pipeline rehabilitation project, but is in sectors including oil and gas extraction, banking, agro-processing, telecommunications, and light industry. The main source countries for investment are the United States, the United Kingdom, Turkey, and Russia. Second, FDI should increase in 1998, based upon the plans of existing investors, interest expressed by several large potential investors, and the increasing pace of large-scale privatization. Third, reforms in tax and customs administration in the last three years have tripled tax revenue as a percent of GDP, providing the basis for Georgia's economic stabilization. Enterprises which have been transferred to the Large Taxpayer Unit of the Tax Inspectorate generally report that this office is more business-like, although it is not without problems. The Tax Inspectorate has an appeals mechanism which has ruled in favor of the taxpayer in the majority of cases; the existence of this mechanism has not been well publicized.

76. The positive trends with FDI reflect the combination of profitable business opportunities and adequate overall legislation, which have-so far-overcome other obstacles in the economy. A new foreign investment law was enacted in November 1996 which allowed unlimited repatriation of capital and profits and placed no limitations on holding foreign currency bank accounts. Foreign investors are required to register, but this is straightforward and the penalties for not doing so are small. Foreign residents are not permitted to own 
agricultural land, but they can lease it. As noted above, the legal framework for urban and industrial land privatization has not been established, but foreign residents can buy buildings and lease land in the same way as domestic residents.

77. Finally, many foreign investors seek the official support needed to succeed in Georgia's business environment in various ways: through a joint venture partner, by appealing to the Foreign Investment Council of the President, through their embassy, or by developing close relations with key officials. Investors report some success in getting problems solved through these sources, but small firms have had much less success, and large firms cannot turn to the government with every small problem. To improve the legislative base for investment, investors can work through the Investment Legislative Support Council of the Chairman of parliament. The World Bank and United Nations have financed the Georgia Investment Center, which provides information to foreign investors and promotes Georgia as a destination for investment.

Text Table 1. Foreign Investment (In millions of US\$)

\begin{tabular}{lcc}
\hline & 1996 & 1997 \\
\hline USA & Actual & Actual \\
United Kingdom & 8.2 & 48.2 \\
Turkey & 7.9 & 25.5 \\
Bermuda Islands & 3.1 & 25.0 \\
Russian Federation & 18.0 & 2.0 \\
Italy & 3.7 & 16.9 \\
Australia & 1.0 & 8.1 \\
South Korea & 5.4 & 7.8 \\
Azerbaijan & 2.0 & 7.0 \\
Norway & 1.5 & 6.5 \\
Israel & 1.3 & 5.6 \\
Germany & 0.0 & 4.2 \\
France & 0.5 & 3.1 \\
UAE & 0.0 & 3.0 \\
Japan & 0.1 & 2.6 \\
Greece & 0.6 & 2.5 \\
Saudi Arabia & 0.0 & 2.0 \\
Ukraine & 0.3 & 1.1 \\
Total & 0.0 & 0.3 \\
Sotres & 53.3 & 189.3 \\
\hline
\end{tabular}

Source: Foreign Investment Survey.

\section{REVENUE MOBILIZATION: THE LAST THREE YEARS}

78. This section summarizes Georgia's tax policy and tax administration developments since December 1994 and compares general government revenue performance in Georgia with 
revenue performance in other BRO countries, highlighting some of the tasks ahead for the Georgian tax authority. The section shows that the number of major tax policy and tax administration measures adopted during the last three years has been declining over time. While a front-loading of major policy measures at the beginning of the stabilization was crucial to swiftly reduce domestic and external imbalances, the problem has been that marginal increases in tax revenue collections has also been diminishing overtime, despite pressing needs to finance some basic public expenditure programs. These trends on fiscal policy and revenue collections raise important questions about the future direction of fiscal policy, including tax enforcement and governance issues, which would need to be addressed in the context of comprehensive economic programs for the coming years.

\section{Tax policy and tax administration measures}

79. To take inventory of all tax policy measures implemented in the last three years, this section classifies measures in four broad categories depending on their potential ${ }^{28}$ revenue impact: (i) tax rate increases (TRI); (ii) tax rate reductions (RTR); (iii) broadening of the tax base (BTB); and (iv) narrowing the tax base (NTB). Whenever a measure has a positive revenue impact, it is graded with an important $(+++)$, moderate $(++)$ or small $(t)$ positive mark. Similarly, whenever a measure has a negative effect on tax revenues it is graded with an important (--), moderate (--), or small (-) negative mark. To evaluate the (net) revenue impact of a set of policies over a period of time, we subtract the number of negative marks $(-)$ from the number of positive marks $(+)$ over the period.

80. Three main conclusions are derived from our inventory of fiscal measures (Text Table 2). First, the net revenue effect of tax policy measures has been positive, but declining over time. During the period December 1994/December 1995, the net effect of the measures adopted was very positive and equal to $15+$. In 1996, the net positive effect was reduced to $5+$, and in 1997 it was just $1+$. Second, during the last three years, measures oriented to expand the tax base (BTB) were more numerous and more important than measures aimed at increasing tax rates (TRI). Indeed, during this period, there were eleven times when BTB measures were enacted with a total potential revenue impact of $22+$, whereas TRI measures were only enacted four times and had a potential revenue impact of 12+. Third, while in 1995 the emphasis to increase tax rates and expand the tax base was somewhat balanced, this emphasis changed over time as BTB measures became the core of the fiscal package.

\footnotetext{
${ }^{28}$ Notice that the potential revenue effect does not necessarily coincide with the actual revenue yield derived from the measures.
} 
Text Table 2. Tax Policy Measures and their Revenue Impact

\begin{tabular}{|c|c|c|c|}
\hline Date & Measure & Type & Potential Revenue Impact \\
\hline December 1994 & $\begin{array}{l}\text { Increase in general VAT rate from } 14 \text { to } \\
20 \text { percent }\end{array}$ & TRI & +++ \\
\hline December 1994 & $\begin{array}{l}\text { Introduction of } 10 \text { percent VAT rate on } \\
\text { bread and flour }\end{array}$ & BTB & ++ \\
\hline December 1994 & $\begin{array}{l}\text { Increase in customs tariff from } 2 \text { to } \\
12 \text { percent }\end{array}$ & TRI & ++ \\
\hline December 1994 & $\begin{array}{l}\text { Increase in the excise tax rate on gasoline } \\
\text { from } 10 \text { to } 15 \text { percent }\end{array}$ & TRI & $H$ \\
\hline December 1994 & $\begin{array}{l}\text { Elimination of the tax on exports to non- } \\
\text { BRO countries }\end{array}$ & NTB & - \\
\hline December 1994 & Increase in VAT threshold & NTB & - \\
\hline February 1995 & $\begin{array}{l}\text { Introduction of a presumptive tax on } \\
\text { individuals and small enterprises }\end{array}$ & BTB & + \\
\hline May 1995 & $\begin{array}{l}\text { VAT levied from non-BRO goods arriving } \\
\text { via BRO countries }\end{array}$ & BTB & + \\
\hline June 1995 & $\begin{array}{l}\text { Elimination of the excise tax exemption on } \\
\text { BRO imports }\end{array}$ & BTB & + \\
\hline June 1995 & $\begin{array}{l}\text { Increase in excise taxes on alcoholic } \\
\text { beverages (except wine) and cars }\end{array}$ & TRI & + \\
\hline June 1995 & Reduction in the excise tax rate on wine & RTR & - \\
\hline June 1995 & $\begin{array}{l}\text { Reduction in the number of excisable } \\
\text { products }\end{array}$ & NTB & - \\
\hline July 1995 & $\begin{array}{l}\text { Elimination of the general tax exemption (on } \\
\text { payment of VAT, income and profit tax, and } \\
\text { customs duty) of the religious patriarchate }\end{array}$ & BTB & + \\
\hline August 1995 & $\begin{array}{l}\text { Elimination of the VAT on imports of capital } \\
\text { goods }\end{array}$ & NTB & -- \\
\hline September 1995 & $\begin{array}{l}\text { Introduction of an entry tax in Georgia and a } \\
\text { tax on the ownership of cars }\end{array}$ & BTB & + \\
\hline $\begin{array}{l}\text { Net December 1994- } \\
\text { December } 1995\end{array}$ & & & $15+$ \\
\hline
\end{tabular}

${ }^{29}$ Actually, the authorities have been implementing a zero VAT rate on domestic flour through 1997. 


\begin{tabular}{|c|c|c|c|}
\hline Date & Measure & Type & Potential Revenue Impact \\
\hline March 1996 & $\begin{array}{l}\text { Removal of VAT exemptions on alcoholic } \\
\text { beverages, certain foodstuffs, and other } \\
\text { goods and services }\end{array}$ & BTB & ++ \\
\hline March 1996 & $\begin{array}{l}\text { Removal of many small income and profit tax } \\
\text { exemptions }\end{array}$ & BTB & + \\
\hline March 1996 & $\begin{array}{l}\text { Removal of custom duty exemptions on } \\
\text { personal imports }\end{array}$ & BTB & + \\
\hline March 1996 & $\begin{array}{l}\text { Reduction of the tax on dividend from } 20 \text { to } \\
10 \text { percent }\end{array}$ & RTR & - \\
\hline March 1996 & $\begin{array}{l}\text { Reduction in the custom duty rate on barter } \\
\text { trade from } 20 \text { to } 12 \text { percent }\end{array}$ & RTR & - \\
\hline May 1996 & $\begin{array}{l}\text { Tea exports to BRO countries taxed at zero } \\
\text { VAT rate }\end{array}$ & RTR & - \\
\hline Net 1996 & & & $5+$ \\
\hline January 1997 & $\begin{array}{l}\text { Removal of VAT and Custom Duty } \\
\text { exemptions for petroleum products and } \\
\text { automobiles }\end{array}$ & BTB & $H$ \\
\hline January 1997 & $\begin{array}{l}\text { Introduction of a } 5 \text { percent custom duty on } \\
\text { limited number of medical goods and raw } \\
\text { materials }\end{array}$ & BTB & + \\
\hline January 1997 & $\begin{array}{l}\text { Reduction in most excise tax rates (except } \\
\text { wine, certain hard alcohols high-quality } \\
\text { cigarettes and petroleum products) }\end{array}$ & RTR & - \\
\hline January 1997 & Unification of profit tax at 20 percent & RTR & - \\
\hline January 1997 & $\begin{array}{l}\text { Reduction in payroll taxes from } 35 \text { to } \\
33 \text { percent }\end{array}$ & RTR & - \\
\hline October 1997 & $\begin{array}{l}\text { Introduction of a specific tax on high-quality } \\
\text { cigarettes of lari } 0.25 \text { per pack; and tax on } \\
\text { low-quality cigarettes of lari } 0.19 \text { per pack }\end{array}$ & TRI & $H+$ \\
\hline Net 1997 & & & $1+$ \\
\hline
\end{tabular}

81. An inventory of the tax administration measures implemented during the last three years shows that the number of administrative measures also declined over time. In 1995 there were 8 significant tax/customs administration measures, whereas this number fell to 4 in 1996 and 1997. These numbers alone, however, do not capture the far-reaching effect of some of these measures like the new tax code enacted in June 1997. 
Text Table 3. Tax and Customs Administration Improvements

\begin{tabular}{|c|c|}
\hline Period & Measure \\
\hline $\begin{array}{l}\text { December 1994/December } \\
1995\end{array}$ & $\begin{array}{l}\text { Interest charged on underpaid tax increased from } 0.3 \text { to } 0.5 \text { percent monthly } \\
\text { Introduction of penalties on nonfiling } \\
\text { TIG was enabled to temporally close businesses after six months of willful } \\
\text { underpayment of taxes } \\
\text { Initial distribution of Taxpayer Identification Numbers by the TIG } \\
\text { Reorganization of the TIG along functional lines } \\
\text { Custom valuation code introduced } \\
\text { Reorganization of two pilot Regional Tax Inspectorates (RTIs) } \\
\text { Computerization of the TIG headquarters and two RTIs begins }\end{array}$ \\
\hline 1996 & $\begin{array}{l}\text { Establishment of the Large Taxpayers Unit (LTU) } \\
\text { Survey to identify new taxpayers begins } \\
\text { Improvement in the processing of imports (through measures such as } \\
\text { blocking the entry of cargoes until full documentation, monitoring passage of } \\
\text { transit vehicles, etc.) } \\
\text { Computerization of the SCD headquarters }\end{array}$ \\
\hline 1997 & $\begin{array}{l}\text { Enactment of the Tax Code: } \\
\text { 1. The TIG was enabled to assess income through presumptive and indirect } \\
\text { methods } \\
\text { 2. Credit/invoice method for VAT } \\
\text { 3. Improved bonus system for the TIG } \\
\text { Computerization of the VAT form } \\
\text { Enactment of the Customs Code } \\
\text { Computerization of Customs }\end{array}$ \\
\hline
\end{tabular}

Fiscal measures and revenue increases, 1994-97

82. Another inference from the data is that there appears to be a close relationship between the adoption of tax policy measures and the increase in the tax revenue to GDP ratio the following year (Text Table 4). Indeed, the largest revenue increase happened in 1996, a 
year after the implementation of a number of "important" (i.e., graded at 15+) tax measures. In 1997, the increase in the tax ratio was more modest, probably reflecting a reduced number of tax policy measures implemented in 1996 (i.e., graded at 5+). This one-year lag between the introduction of tax policy measures and actual tax collections suggests that significant increases in tax collections require the implementation of bold revenue raising measures a year ahead. The adoption of revenue-raising tax policy measures seems fundamental for increasing tax collections even in a country like Georgia, where tax administration measures could make a major contribution to revenue collections.

\section{Text Table 4. Fiscal Developments and Increase in the Tax Revenue/GDP ratio}

\begin{tabular}{|l|c|c|c|}
\hline Year & $\begin{array}{c}\text { Potential Revenue Impact of } \\
\text { Tax Policy Measures }\end{array}$ & $\begin{array}{c}\text { Tax Administration } \\
\text { Measures }\end{array}$ & $\begin{array}{c}\text { Percentage } \\
\text { increase in general } \\
\text { government tax } \\
\text { revenue/GDP } \\
\text { ratio }\end{array}$ \\
\hline 1995 & $15+$ & 8 & 24.3 \\
\hline 1996 & $5+$ & 4 & 56.5 \\
\hline 1997 & $1+$ & 4 & 24.7 \\
\hline
\end{tabular}

\section{Comparison with other BRO countries}

83. Text Table 5 compares fiscal performance in Georgia with performance in other BRO countries. The comparison shows that Georgia's revenue/GDP ratio has almost tripled since 1993, but the tax level only represented about one-third of the unweighted average of BRO countries in $1997 .{ }^{30}$ Although the low revenue/GDP ratio could be partially related to an overestimation of the GDP, it is clear that there is substantial room to increase tax revenue in Georgia. Options available include the elimination of existing VAT exemptions and broadening the tax bases of the income and payroll tax. As in many other BRO countries, further efforts are also required to eliminate tax arrears (which currently represents about 30 percent of total tax collection), fight corruption in the tax and customs administrations, and improve the judicial system.

\footnotetext{
${ }^{30}$ International comparisons of Georgia's fiscal performance need to be treated with caution, however, as Georgia's official GDP estimates may be overestimated. Extensive IMF technical assistance in the area of national accounts statistics is currently being provided to Georgia's State Department of Statistics.
} 
Text Table 5. BRo Countries: General Government Revenue Developments 1993-97 (Total revenue, in percent of GDP)

\begin{tabular}{|c|c|c|c|c|c|c|}
\hline & \multirow[b]{2}{*}{1993} & \multirow[b]{2}{*}{1994} & \multirow[b]{2}{*}{1995} & \multirow[b]{2}{*}{1996} & \multicolumn{2}{|c|}{$\mathrm{O} 1-02$} \\
\hline & & & & & 1996 & 1997 \\
\hline Armenia & 16.0 & 15.8 & 16.2 & 16.2 & 11.5 & 14.3 \\
\hline Azerbaijan & 40.6 & 26.1 & 15.2 & 16.2 & 14.4 & 17.6 \\
\hline Belarus & 54.7 & 48.3 & 42.7 & 41.9 & 44.2 & 46.5 \\
\hline Estonia & 38.5 & 41.3 & 39.9 & 39.0 & 38.3 & 39.0 \\
\hline Georgia & 3.4 & 4.2 & 5.1 & 8.1 & 6.8 & 8.9 \\
\hline Kazakahstan & 29.9 & 25.6 & 26.1 & 23.6 & 26.8 & 23.4 \\
\hline Kyrgyz Republic & 24.6 & 20.8 & 16.7 & 17.0 & 20.2 & 20.7 \\
\hline Latvia & 35.8 & 36.5 & 35.5 & 36.4 & 36.3 & 39.7 \\
\hline Lithuania & 31.5 & 32.7 & 32.8 & 30.0 & 29.6 & 33.9 \\
\hline Moldova & 22.1 & 32.0 & 33.5 & 31.5 & 27.3 & 30.6 \\
\hline Russia & 36.2 & 34.6 & 27.9 & 24.7 & 24.3 & 24.3 \\
\hline Tajikistan $1 /$ & 27.1 & 44.5 & 15.2 & 12.3 & 15.0 & 12.2 \\
\hline Turkmenistan $2 /$ & 19.2 & 10.4 & 12.5 & 15.1 & 8.7 & 17.1 \\
\hline Ukraine & 42.8 & 44.3 & 38.5 & 37.2 & 35.2 & 37.2 \\
\hline Uzbekistan $\underline{3} /$ & 42.6 & 32.3 & 34.6 & 34.2 & 44.1 & 39.3 \\
\hline Unwieghted Average 4 / & 31.3 & 28.9 & 26.9 & 26.5 & 26.3 & 28.0 \\
\hline Unweighted Average $\underline{4} / \underline{5} /$ & 30.2 & 26.8 & 24.5 & 24.2 & 23.9 & 25.4 \\
\hline Weighted Average 6/ & 36.3 & 34.6 & 28.7 & 25.9 & 25.7 & 25.9 \\
\hline
\end{tabular}

Sources: Data provided by the authorities; and Fund staff estimates.

1/Data for Tajikistan are not strictly comparable across years due to the falling value of non-cash rubles in 1994 and 1995 and the change of the national currency in mid-1995. State budget only.

2/Including grants.

3/ Excluding Tajikistan.

4/Excluding Tajikistan.

5/Excluding Baltic countries.

6/ Weights based on output in 1994. 


\section{Text Table 6. BRO Countries: General Government Revenue Developments by Type of Tax, 1997 Q1-Q2 (Tax revenue, in percent of GDP)}

\begin{tabular}{lcccccc}
\hline & Profit & $\begin{array}{c}\text { Individual } \\
\text { Income }\end{array}$ & Payroll & $\begin{array}{c}\text { VAT and } \\
\text { Other Indirect }\end{array}$ & Trade & Other \\
\hline Armenia & 1.9 & 0.9 & 2.8 & 5.1 & 1.7 & 1.9 \\
Azerbaijan & 2.8 & 2.0 & 2.4 & 5.2 & 1.5 & 3.7 \\
Belarus & 4.5 & 3.3 & 12.1 & 14.2 & 2.8 & 9.5 \\
Estonia & 2.3 & 2.3 & 12.4 & 13.1 & 0.0 & 3.1 \\
Georgia & $\mathbf{0 . 7}$ & $\mathbf{1 . 0}$ & $\mathbf{1 . 6}$ & $\mathbf{3 . 1}$ & $\mathbf{0 . 6}$ & $\mathbf{2 . 0}$ \\
Kazakhstan & 2.7 & 2.4 & 7.6 & 4.0 & 0.4 & 6.3 \\
Kyrgyz Republic & 1.9 & 1.6 & $\ldots$. & $\mathbf{8 . 4}$ & 0.8 & 5.2 \\
Latvia & 2.4 & 5.5 & 11.3 & 12.9 & 0.7 & 7.4 \\
Lithuania 1/ & 1.9 & 5.1 & 11.7 & 12.3 & 0.8 & 2.1 \\
Moldova & 1.8 & 2.4 & 9.2 & 9.9 & 1.0 & 6.3 \\
Russia & 2.9 & 2.1 & 6.9 & 6.6 & 0.8 & 5.0 \\
Tajikistan & 1.2 & 1.3 & $\ldots$. & 7.3 & 1.5 & 1.7 \\
Turkmenistan & 2.7 & 0.6 & 1.7 & 5.3 & 0.0 & 6.8 \\
Ukraine & 4.9 & 3.7 & 11.4 & 9.6 & 0.7 & 5.4 \\
Uzbekistan & 10.6 & 4.8 & $\ldots$ & 17.3 & 0.8 & 6.6 \\
& & & & & & \\
Unwt. Average & 3.0 & 2.6 & 7.6 & 9.0 & 0.9 & 4.9 \\
\hline Sourcs: Data provided & & & & & &
\end{tabular}

Sources: Data provided by the authorities; and Fund staff estimates.

1/The Health Insurance Fund was added to payroll taxes as of January 1997.

84. A comparison between revenue collections by type of tax in Georgia and in other BRO countries (Text Table 6 and Figure 9) highlights two main conclusions. First, for all tax categories, revenue/GDP ratios in Georgia are lower than elsewhere in the region. Second, the under performance of some taxes in Georgia is particularly striking. Indeed, the ratio of payroll taxes to GDP in Georgia was only one-fifth of the unweighted average ratio for BRO countries in 1997 (1.6 percent of GDP versus 7.6 percent of GDP). Since the combined payroll tax rate of 33 percent in Georgia is within the 31-45 percent range in other BRO countries, low payroll tax collections suggest that there is much room for improvement with this tax. Profit tax collections in Georgia are also very limited compared with those in other BRO countries. In this case, however, the rather low profit tax rate in Georgia (20 percent, versus $35-40$ percent in many other BRO countries) might explain the limited collections from this tax.

\section{INTEREST RATE DEVELOPMENTS}

85. This section discusses the interest rate developments in Georgia during 1997 and early 1998. A description of the nascent treasury bill market is followed by a discussion of interest rate trends in the money market and commercial banks' lending and deposit rates. 
Figure 9. Georgia and BRO: Composition of Total Revenue, 1997 Q1-Q2

BRO (Unweighted average)

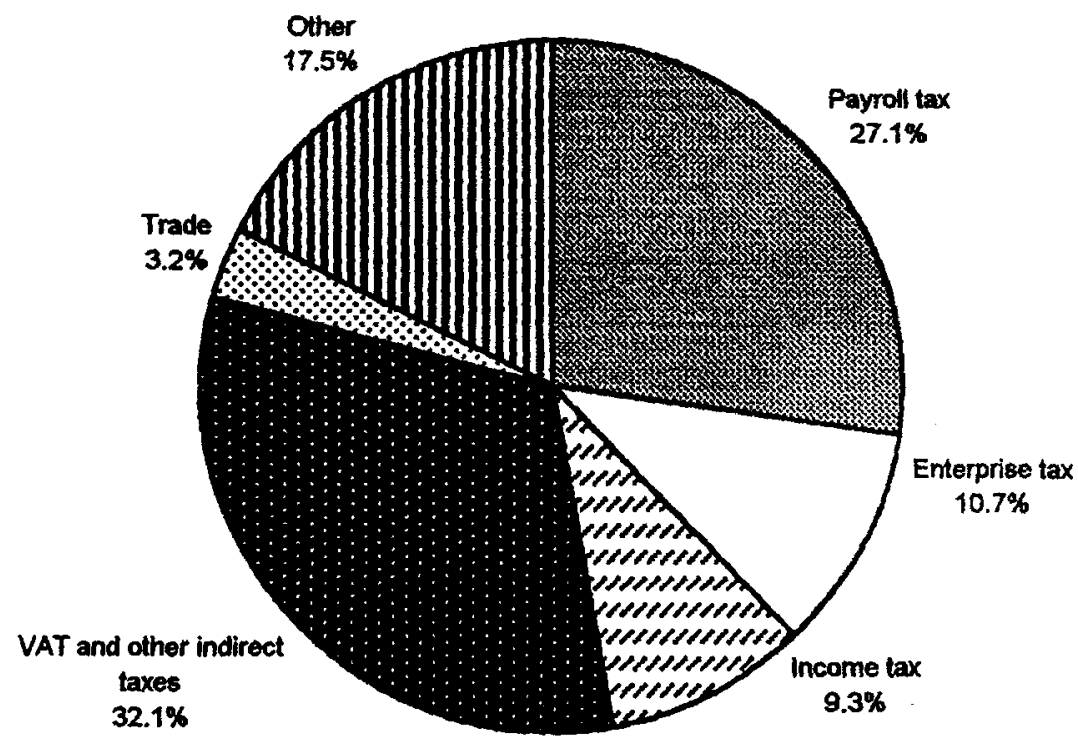

Georgia

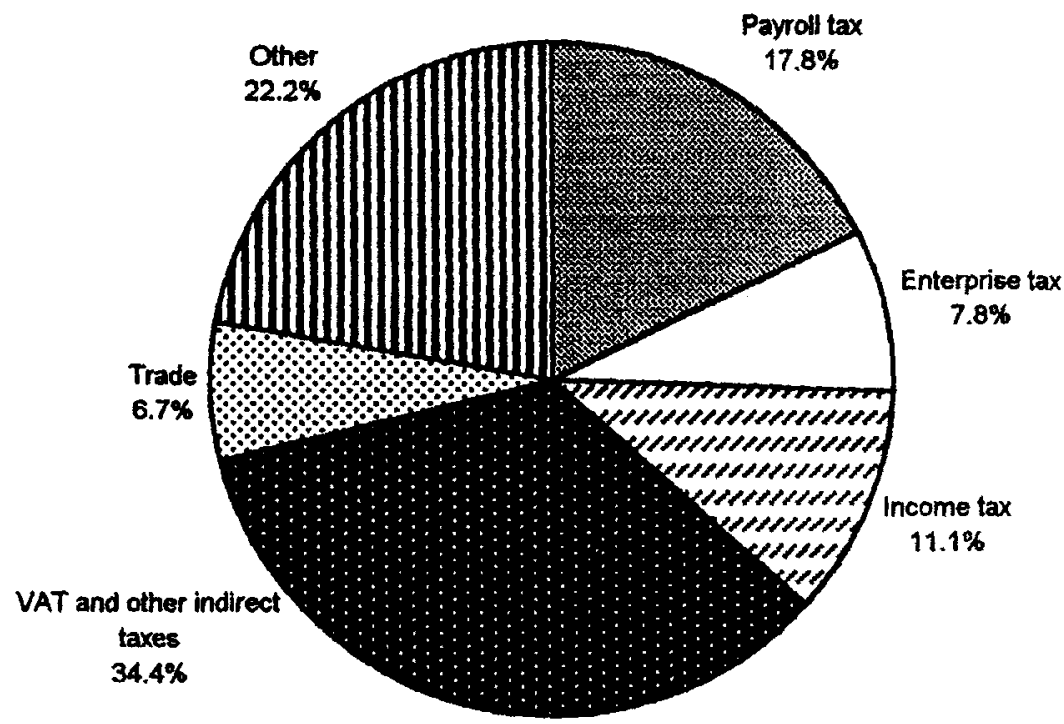

Sources: National authorities. 


\section{Treasury bill market}

86. Primary treasury bill auctions were introduced in Georgia in August 1997. Initially the maturity of the treasury bills auctioned in the primary market was limited to 28-day bills only, but starting from November bills with 91-day maturity also became available. Participation in the primary auctions has been limited to licensed commercial banks. Other interested buyers including nonresidents can purchase treasury bills through licensed banks. The NBG does not participate in the primary market and a secondary market has not yet been developed. The outstanding stock of treasury bills was about lari 6 million (1.6 percent of M3) at end-1997, of which lari 2.8 million had a 28-day maturity and lari 3.2 million had a 91-day maturity (Figure 10). Nonresidents held nearly one third of treasury bills outstanding at end-1997. The rest of the treasury bills were held by very few banks. ${ }^{31}$ The average frequency of primary auctions has been once a month for the 28-day bills and twice a month for the 91-day bills.

87. Despite the decline of annual inflation to single digits, the treasury bill yield prevailing in the primary market has been very high, averaging about 37 percent (on an annual basis) during the period August 1997-February 1998. The yield has also been very volatile. After hovering around 30 percent during August-October $1997,{ }^{32}$ the yield went up slightly in November and bounced to 45 percent in December for both 28-day and 91-day bills. The yield fell moderately in early 1998, to about 35 percent for 28 -day bills and just under 40 percent for 91-day bills at end-March 1998. While the volatility in the treasury bill yield may in part be related to a rather thin primary market for these financial instruments and the authorities' lack of experience in this area, the yield level reflected mainly the stance of fiscal policy. In particular, while overall liquidity conditions were very tight in October/December 1997, offerings of treasury bills in the primary market increased significantly as the government tried to fulfill its ambitious expenditure plan. ${ }^{33}$ As a result, the auction coverage (i.e., the ratio between total bids and total offerings of treasury bills) declined significantly in those two

\footnotetext{
${ }^{31}$ Out of 47 licensed commercial banks, only about five have so far participated in the auctions on a regular basis.
}

${ }^{32}$ Following a 30 percent yield in the introductory 28-day bill auction in August, the yield declined to 23 percent in September but bounced up to 32 percent in October.

${ }^{33}$ The banking sector's deposit liabilities increased by over lari 50 million during the period January-August 1997, equivalent to about 70 percent increase relative to end-1996, but remained flat between September and December 1997. Despite a continued increase in households deposits, total bank deposits actually declined in nominal terms during December 1997, largely reflecting a significant increase in tax payments by the enterprise sector that normally takes place at year end. 
Figure 10. Georgia: Oustanding Stock of Treasury Bills and Weighted Average Interest Rates 1/

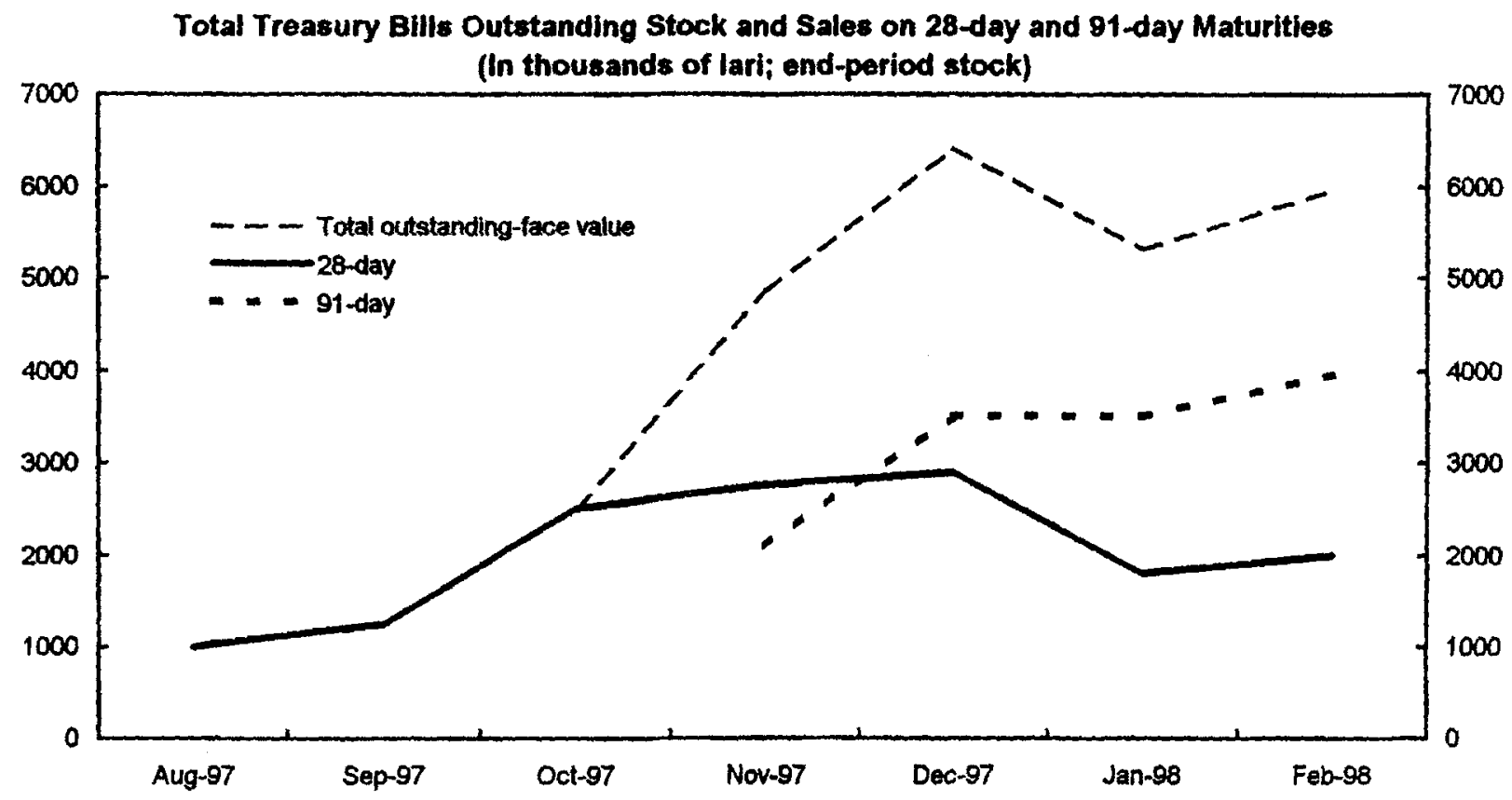

Weighted Average Interest Rate on 28-day and 91-day Treasury Bills (In percent)

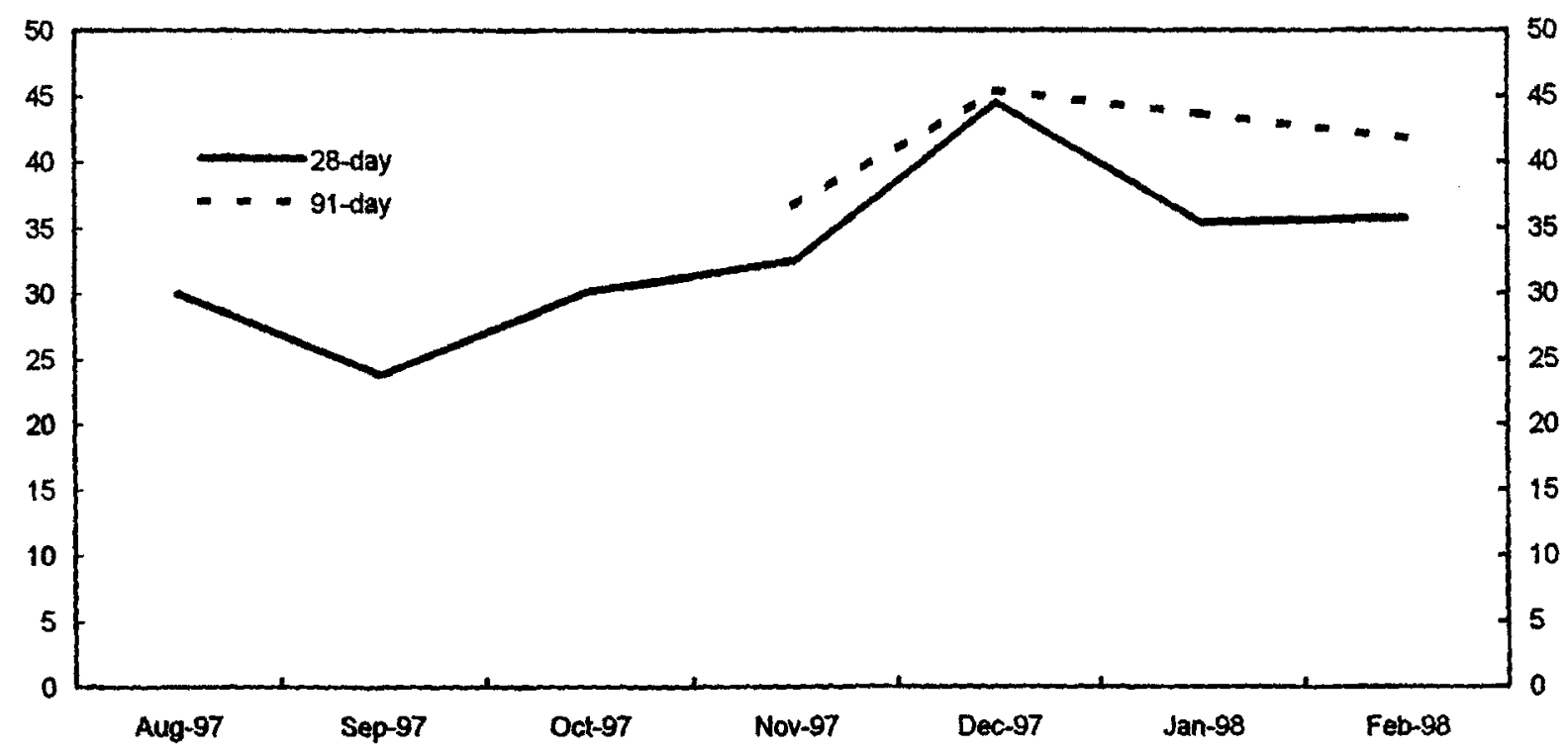

Sources: National Bank of Georgia.

1/ Treasury bills with 28-day maturity were introduced in August 1997; treasury bills with 91-day maturity were introduced in November 1997. 
months and the December 91-day bill auction was undersubscribed by nearly half, contributing to a sharp increase in the yield by year end. ${ }^{34}$

88. The level of the treasury bill yield is likely to come down in 1998 and fluctuations in the yield should become smoother, as the fiscal deficit declines and the scheduled treasury bill offerings in the primary market for 1998 take better into account the seasonality of the market's liquidity conditions. In addition, the NBG intends to introduce a floor-based secondary market in the second half of 1998 to encourage the secondary trading of treasury bills.

89 As a conclusion, given the relatively short time since the introduction of the primary treasury bill market in Georgia and the virtual absence of a secondary market, the treasury bill yield is not yet a good indicator of the market interest rate.

\section{Money market developments}

90. Developments in Georgia's money market were characterized by a sharp increase in the interest rate level during the second half of 1997, following a moderate decline in the first half of the year (Figures 11-13). ${ }^{35}$ The NBG does not provide any automatic refinancing credit to commercial banks, and as noted earlier, it does not participate in the primary treasury bill market while a secondary market has yet to be developed. Its intervention in the credit auction market therefore, apart from reserve requirements, is the main channel for the NBG to influence the market interest rate in Georgia. ${ }^{36}$

91. In a departure from 1996, interest rate developments in the money market during 1997 were shaped by the NBG's objective to maintain the stability of the lari exchange rate, while targeting an appropriate level of international reserves. During the second half of 1996, in an effort to reduce the general level of interest rates in Georgia, and in so doing to make lending possible to sectors other than trade, the NBG stepped up considerably its sales in the interbank credit market. Concretely, the NBG sales in the credit auction market increased from an average of 0.25 lari million a month to lari 3.5 million per month in the second half of the year, with lari 10 million in December alone. During the period January-April 1997, the NBG sales in credit auction continued to be high averaging lari 4.4. million a month. While this policy led to a significant reduction in the money market interest rates, it contributed to

\footnotetext{
${ }^{34}$ The increase in Treasury bills' yields at end-1997 was not accompanied by pressures in the foreign exchange market, as monetary policy remained tight during this period.

${ }^{35}$ Following a moderate improvement of the market's liquidity conditions in early 1998 , the money market interest rate declined somewhat during January and February.

${ }^{36} \mathrm{An} \mathrm{NBG}$ refinancing facility (at below-market interest rates) was available to banks until end-1994, but has since been discontinued.
} 
Figure 11. Georgia: Total Volume of Transactions, NBG Sales at the Interbank Credit Auctions and 7-day Maturity Average Interest Rate Per Annum

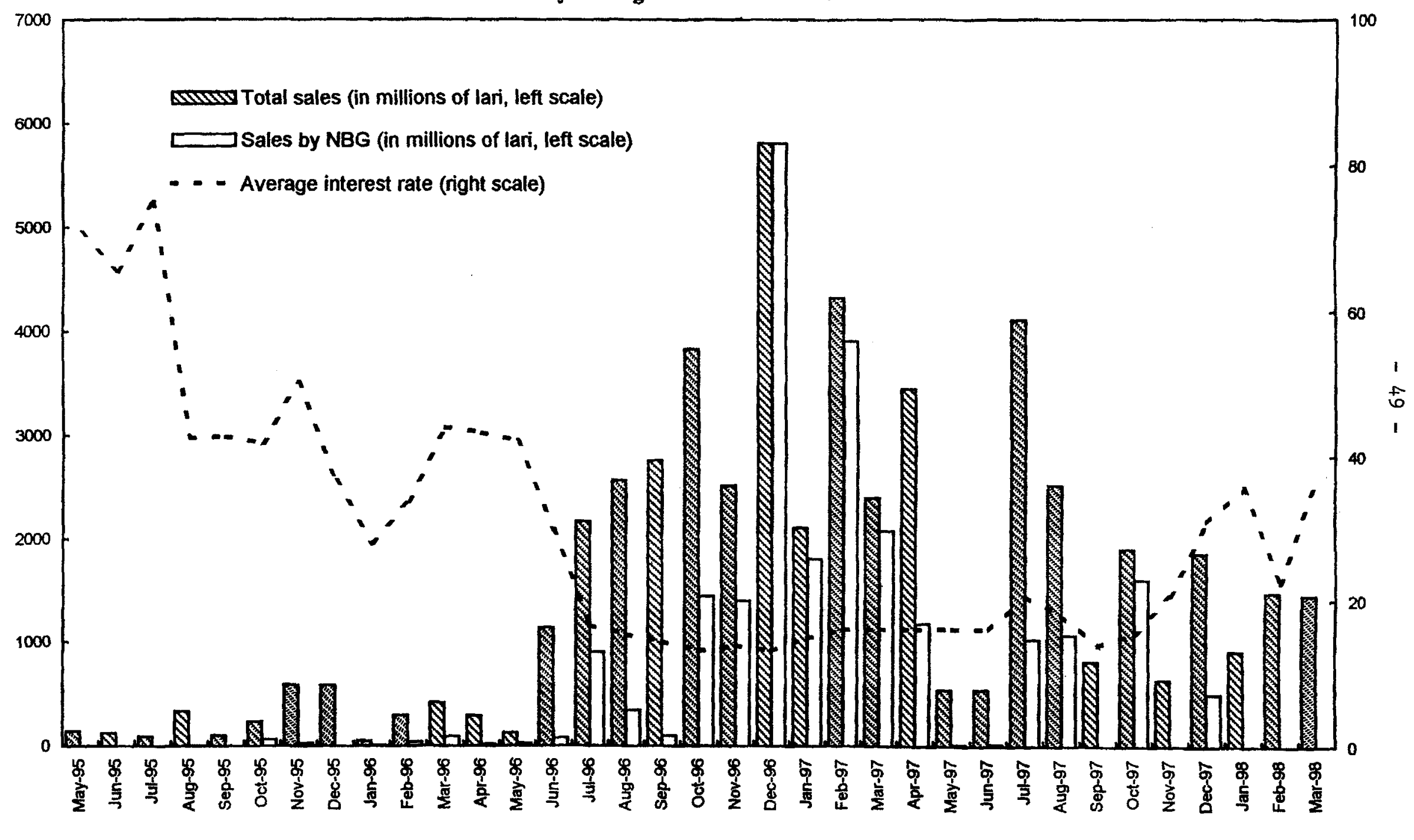

Sources: National Bank of Georgia; and Fund staff estimates. 
Figure 12. Georgia: Total Volume of Transactions, NBG Sales at the Interbank Credit Auctions and 30-day Maturity Average Interest Rate Per Annum

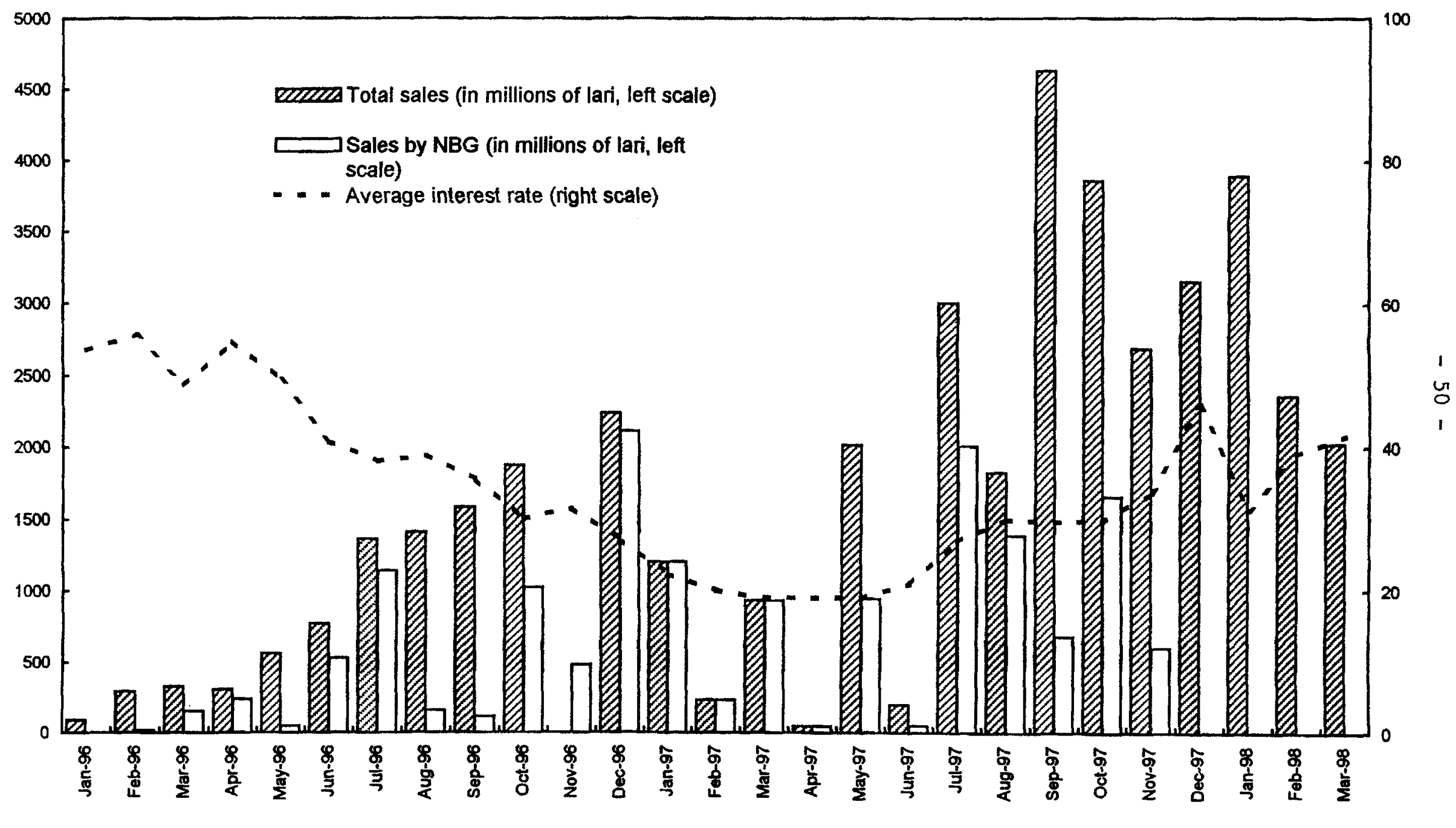

Sources: National Bank of Georgia; and Fund staff estimates. 
Figure 13. Georgia: Total Volume of Transactions, NBG Sales at the Interbank Credit Auctions and 90-day Maturity Average Interest Rate Per Annum

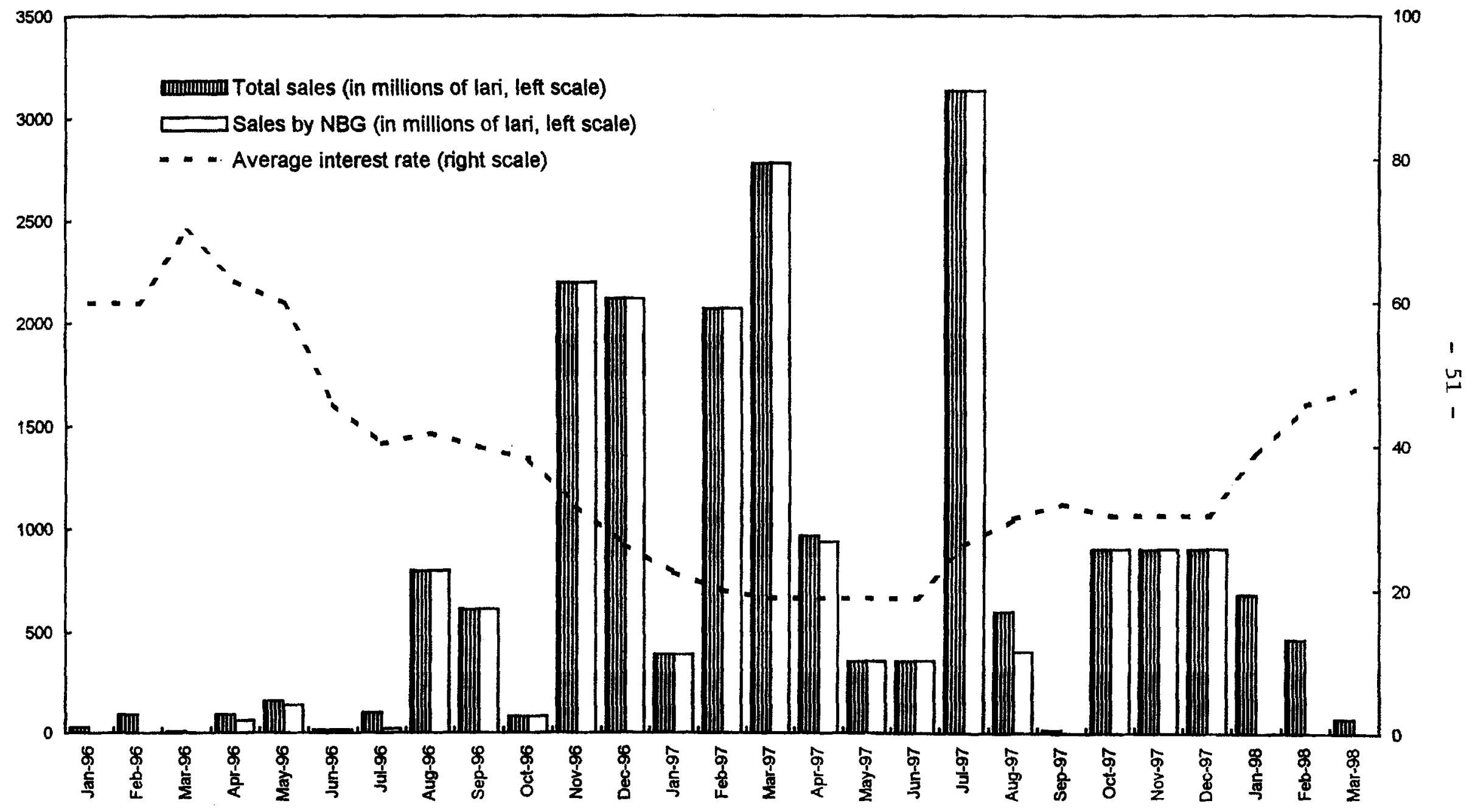

Sources: National Bank of Georgia; and Fund staff estimates. 
increased pressures in the TICEX market and ultimately led to additional NBG sales of foreign exchange reserves in order to defend the lari exchange rate. During 1997, starting from May 1997, however, in order to maintain an adequate level of international reserves, the NBG scaled down significantly its sales in the credit auction market, which contributed to a sharp increase in the money market's interest rate level during the second half of the year. The interest rate on interbank credit auction market on very short maturities, increased from 13 percent and 20 percent (on an annual basis) at end-1996, respectively, for 7-day and 30 -day credits, to 31 percent and 46 percent at end-1997, respectively. The interest rate on 90-day maturity credits also increased from 26 percent at end-1996 to 30 percent at endOctober 1997, while no transactions took place at this maturity during November and December 1997.

92. Following the reduced participation of the NBG in the interbank credit auction market, the outstanding stock of the NBG credit to commercial banks declined from about lari 14 million at end-1996 to lari 3.5 million at end-1997. While the commercial banks' participation in the credit auction market with 7-day and 30-day maturity increased significantly during 1997 , the NBG remains virtually the sole supplier of credit in the money market with 90-day maturity.

\section{Commercial banks interest rates}

93. Nominal interest rates on banks' deposits continued to fall during 1997 , following the decline of annual inflation to single digits. The average dollar and lari deposit rate declined from 16 percent at end-1996 to about 13 percent at end-1997 (Appendix I, Table 32 and Figure 14). Banks appear to have been competing vigorously in the market for deposits given the tightening of the NBG credit policy toward banks by mid-1997 as noted above. Newly established commercial banks are more aggressive in this regard and offer, on average, higher deposit rates on lari and dollar deposits than the FSBs. This has contributed to a further decline in the FSBs' share in total deposit liabilities relative to the rest of the banking sector, particularly as regards the households deposits. At end-1997, the FSBs' share in households deposits declined to about 30 percent compared to over 45 percent at end-1996. The prevailing interest rates offered by the ten largest banks on foreign currency deposits remain about 10 percentage points above the deposit rates in industrial countries. On average, the rate on foreign currency deposits is virtually identical with, and in some cases higher than, the interest rate on domestic currency deposits. The later could be one of the main factors behind the increased dollarization of commercial bank deposits observed during 1997.

94. Banks' lending rates also declined during 1997, but at a faster pace relative to the decline in deposit rates, leading to a moderate reduction in the spread between lending and deposit rates. While the three-month lending interest rate declined from 53 percent (on an annual basis) at end-1996 to about 45 percent at end-1997, the spread between lending and deposit rates declined from about 37 percent at end-1996 to about 32 percent at end-1997. Despite the continued trend decline during 1997, the interest rate spread prevailing in Georgia 
Figure 14. Georgia: Interest Rates, 1995-98

(In percent per annum, quarterly average)

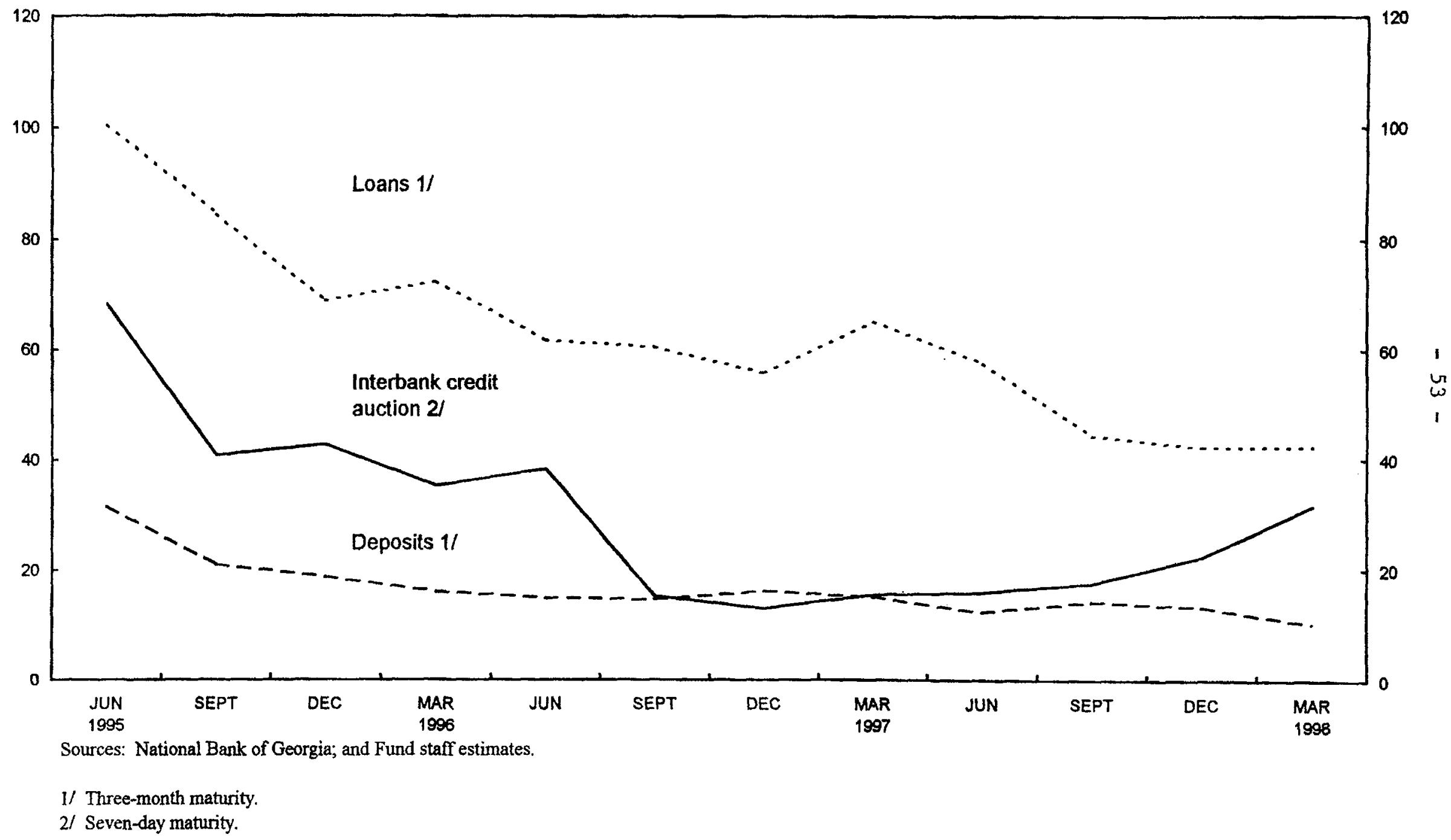


at end-1997, three and a half years after the halt of the hyperinflation, ${ }^{37}$ appears to be very high compared to the spread prevailing in other BRO as well as a number of developing countries that have gone through banking sector crises (Text Tables 7 and 8).

95. A main reason behind the high spread level in Georgia appears to be the slower progress in enterprise and judicial reform, which make the preparation of adequate loan risk analysis very difficult and the seizure of delinquent borrower's assets an almost impossible task. Other factors behind the high interest rate spread appear to include: (i) the banks' efforts to increase their capital base, in view of the announced schedule by the NBG to increase the banks' minimum capital gradually to lari 5 million by year 2000 from about lari 0.2 million at end-1997; (ii) a severe credit rationing given an extremely low deposit base relative to the GDP, which enables banks to lend mainly to trade-related activities that have a quick turnover and high profit margins; (iii) underlying inefficiencies of Georgia's banking sector; and (iv) the small size of banks in Georgia. The spread is, on average, higher for the FSBs relative to the rest of the banking sector's, reflecting mainly a larger nonperforming portfolio of the former. While the spread for FSBs hovered around 40 percent during 1997, it declined to about 25 percent at end-1997 for the rest of the banking sector from about 35 percent at end-1996.

\section{Text Table 7. Interest Rate Spread in Selected BRO Countries, 1995-97 (Period average; in percent per annum)}

\begin{tabular}{lrrr}
\hline & 1995 & 1996 & 1997 \\
\hline Armenia & 71 & 35 & 29 \\
Belarus & 4 & 16 & 8 \\
Estonia & 9 & 6 & 5 \\
Georgia & 62 & 47 & 41 \\
Kazakhstan & $\ldots$ & 11 & 9 \\
Kyrgyz Republic & $\ldots$ & 20 & 23 \\
Lithuania & 16 & 14 & 12 \\
Latvia & 19 & 12 & 7 \\
Moldova & $\ldots$ & 14 & 11 \\
Russian Federation & 36 & 32 & 18 \\
Tajikistan & $\ldots$ & 19 & 15 \\
Turkmenistan & $\ldots$ & $\ldots$ & 20 \\
Ukraine & 33 & 31 & 24 \\
Uzbekistan & $\ldots$ & $\ldots$ & 18 \\
\hline Sources: Auth
\end{tabular}

Sources: Authorities of BRO countries; and staff estimates.

${ }^{37}$ Georgia's high inflation rates turned into hyperinflation in late 1993. The hyperinflation was halted in September 1994 through introduction of tight fiscal and monetary policies. 
Text Table 8: Interest Rate Developments Surrounding the Banking Crises ${ }^{1}$

Argentina Chile Finland Ghana Norway Philippines Uruguay Venezuela

Real interest rate ${ }^{2}$

$\begin{array}{lrlllllll}\text { Mean }_{0} & -4.55 & -6.41 & 0.28 & 2.10 & 2.95 & 4.49 & 9.57 & -8.61 \\ \text { Mean }_{1} & -0.87 & 1.02 & 3.64 & 7.33 & 5.56 & 13.80 & 21.24 & -\end{array}$

Gross interest margins ${ }^{3}$

$\begin{array}{lllllllll}\text { Mean }_{0} & 16.15 & 18.40 & 2.86 & 3.40 & 8.61 & 7.87 & 28.53 & 5.44\end{array}$

\begin{tabular}{lllllllll} 
Mean $_{1}$ & 7.49 & 12.20 & 4.71 & 8.10 & 4.47 & 3.93 & 15.49 & - \\
\hline
\end{tabular}

Sources: Sundararajan and Baliňo (1991), Drees and Pazarbaşioğlu (1995), and IMF, International Financial Statistics.

${ }^{1} \mathrm{Mean}_{0}$ and mean $\mathrm{n}_{1}$ are the sample means for the five-year period before and after each banking crisis, respectively.

${ }^{2}$ Calculated as the nominal short-term interest rate minus the inflation rate.

${ }^{3}$ Lending rate minus deposit rate.

\section{GEORGIA's ACCESSION TO THE WTO}

96. This section updates the status of Georgia's application to the WTO, outlines some outstanding issues, and reviews the economic implications of Georgia's membership.

\section{Update on the accession process}

97. On July 3, 1996, Georgia applied for accession to the WTO under Article XII of the Agreement Establishing the WTO. Upon receiving the official request, the General Council of the WTO established a Working Party to examine Georgia's application and make specific recommendations on its accession. In April 1997, Georgia submitted its Memorandum on the Foreign Trade Regime for distribution among the WTO members, and followed up in October 1997, with written responses to questions submitted by members. On March 3-4, 1998, the Working Party on Georgia's accession to the WTO met for the first time to review recent steps taken by Georgia to bring it closer to conformity with the WTO and to discuss Georgia's initial proposals on market access. In addition, Georgia has begun preliminary bilateral discussions with WTO members on its market access proposals. A second Working Party meeting is expected sometime in the fall of 1998.

98. Recently, Georgia has made legislative changes to bring Georgia more into conformity with the WTO. Laws covering the civil code, tax and customs codes, maritime and aviation codes, and privatization have been adopted. In accordance with WTO guidelines, Georgia is also considering laws on trademarks, government procurement, and copyright and patents. Also as of January 1, 1998, Georgia moved to the destination principle for its indirect taxation 
of exports and imports with other CIS countries, despite lack of agreement with all CIS countries. On March 29, 1998, a new Customs Law came into effect which dismantled the reference price system for customs valuation and replaced it with one based upon the transaction value of the traded good. To facilitate Georgia's accession to the WTO, Georgia's parliament has made a commitment that starting September 1, 1998, all new legislation adopted in Georgia will be in full compliance with the "legal norms" of the EU. Georgia is also undertaking steps to convert from the 1992 system of the Harmonized Tariff System to the 9-digit level 1996 system.

\section{Some outstanding issues}

99. In terms of the required steps for WTO accession, Georgia has benefited greatly from its open trade regime including low and uniform tariff rates adopted shortly after its independence. Despite the favorable initial setting, some outstanding issue still remain. They include:

- Georgia, like other WTO members, would be expected to accept binding limits on tariff rates. Although Georgia's low tariff rates (5 and 12 percent) imply that the setting of binding rates is not likely to become a major issue, it would still be important for Georgia to accept low binding rates so as to prevent the current tariff rates against political pressures to increase them in the future.

Any remaining bans on exports will pose a problem for WTO accession.

- Georgia's use of specific rates on imported alcoholic beverages could raise problems of fair national treatment. According to the WTO, the VAT and excise duty should be applied on the same basis for domestically produced commodities as well as for imports. For example, different treatment of domestically produced and imported beverages with similar alcohol content could result in a form of domestic protection and violate WTO rules on national treatment.

- A decision will have to be taken on Georgia's status as a WTO member. While a case could be made for Georgia being admitted under the status of developing country, in view of the previous selections, it is likely that Georgia will be classified as a transition economy. Status as a transition economy would still allow Georgia to delay the implementation of certain provisions such as subsidies and TRIMs.

\section{Implications for WTO membership}

100. There are several reasons to expect that membership would accelerate Georgia's transition to a more market-oriented economy. First and foremost, guaranteed most favorable nation status and access to the trade-dispute mechanism of the WTO would greatly improve Georgia's access to markets outside the region. Under the WTO, treatment of intellectual 
property rights, financial disclosure, and TRIMs would also improve the environment for foreign investment in Georgia. WTO membership would also possibly strengthen Georgia's position in any discussion of joining the proposed CIS customs union, particularly if the external policy of the CIS union were found to be more restrictive than Georgia's trade regime as a member of the WTO.

\section{EXCHANGE, TRADE AND PAYMENTS SYSTEMS}

101. Georgia accepted the obligations of Article VIII, sections 2, 3, and 4 of the Fund's Articles of Agreement on December 20, 1996.

\section{Exchange arrangements}

102. The currency of Georgia is the lari. The lari became the sole legal tender on October 2, 1995, replacing the coupon, which had been introduced on April 5, 1993, and was declared the sole legal tender on August 3, 1993. For all commercial transactions, the exchange rates of the lari are negotiated freely between the banks and foreign exchange bureaus that are licensed by the NBG, and their customers. In addition, the NBG and the major commercial banks participate in the sessions at the TICEX on each working day. Auctions take place only for the U.S. dollar and the Russian ruble. At these sessions, all transactions take place at the single exchange rate for each currency which balances supply and demand.

103. Between January and August 1996, the official exchange rates for the U.S. dollar and the Russian ruble were determined as the exchange rates arising at the TICEX session of the previous Friday. Since August 12, 1996, the official rates are set daily. Official rates for other convertible currencies are determined on the basis of the cross rates for the U.S. dollar and the currencies concerned in the London market. For the currencies of other BRO states, official exchange rates are determined on the basis of the official cross rates for the Russian ruble as determined in the Moscow market. Official exchange rates are used only for government transactions and accounting purposes. Compulsory sales of foreign exchange by exporters to the NBG have been abolished since January 1996.

104. On December 31, 1997, the official exchange rates were lari 1.304 per U.S. dollar and lari 0.00022 per Russian ruble.

\section{Administration of control}

105. The NBG is responsible for administering exchange control regulations, which are formulated in collaboration with the Ministry of Finance. Decree No. 259, of March 5, 1992, on "The First Stage of Liberalization of Foreign Economic Activity" established the legal basis for the conduct of foreign economic activities in Georgia. The main provisions of this decree: (i) allow all enterprises to engage directly in foreign trade; (ii) allow all residents to acquire 
and hold foreign currency and engage in foreign transactions with a licensed foreign exchange dealer; and (iii) authorize banks to open foreign exchange accounts for all residents.

106. The NBG has the authority to issue general foreign exchange dealing licenses to banks to permit them to engage in foreign exchange transactions with residents and nonresidents and to open correspondent accounts with banks outside of Georgia. The NBG also has the authority to issue internal licenses to banks which permit them to engage in the same range of foreign exchange transactions as general license holders, except that holders of internal licenses may not open correspondent accounts with banks abroad; all transfers of foreign exchange by holders of internal licenses must be carried out through correspondent accounts held either with the NBG or with a bank that holds a general license. The NBG also has the authority to issue licenses for the establishment of exchange bureaus to engage in exchange transactions of all kinds in banknotes.

\section{Prescription of currency}

107. Residents of Georgia may make and receive payments and transfers in any convertible currency.

\section{Resident and nonresident accounts}

108. Resident individuals and enterprises are permitted to open and operate foreign exchange accounts at banks in Georgia. The balances in these accounts may be used for all authorized transactions. The opening of foreign exchange accounts abroad by residents is subject to authorization by the Ministry of Finance and the NBG. Nonresidents may maintain foreign exchange and local currency accounts with banks in Georgia and may freely remit funds from these accounts offshore. The export of cash currency is permitted by non-residents up to a limit equal to the amount of currency originally imported; exports by non-residents of cash in excess of the amount imported by more than US $\$ 500$ but less than US $\$ 10,000$ are subject to a fee of 2 percent, beyond this amount the fee is 3 percent. The export of cash by residents is unrestricted up to an amount of US\$500. Beyond this amount, exports of cash, excluding amounts for business travel expenses, are subject to a 2 percent fee, with amounts over US $\$ 10,000$ subject to a 3 percent fee (Decree No. 1 of January 6, 1995 on Provisional Rules for the Export of Foreign Currency Notes by Citizens, as amended by Decree No. 158 of May 6, 1995).

\section{Imports and import payments}

109. Trade with countries other than the Baltic countries, Russia, and other countries of the former Soviet Union is regulated by the Ministry of Trade and Foreign Economic Relations, which regulates all foreign trade of Georgia (Decree No. 265 on Quotas and licensing of Merchandise Trade of March 31, 1993 and Decree No. 35 of January 23, 1995, on the State Regulations of the Export and Import of Goods and Services). There are no quantitative restrictions on imports, and licenses are generally not required. A customs duty of 12 percent 
is levied on most non-CIS imports as well as imports of fuel from CIS countries; certain goods are subject to a customs duty of 5 percent as of January 1, 1997, including specific capital goods, medical goods, electricity, natural gas, and equipment previously taxed at 12 percent, and certain raw materials. Humanitarian aid, literature published by Georgian citizen abroad, diplomatic shipments, non-commercial imports for internal consumption by cultural groups or certain institutions and activities of the patriarchate, gitts valued at less than US $\$ 3,000$ and personal belongings, goods in transit and for re-export, and various categories of foods and medicines are exempt. All imports are subject to a general customs processing fee of 0.2 percent. Foreign exchange to pay for imports may be purchased freely from authorized banks at market rates.

\section{Exports and export proceeds}

110. A limited range of goods are subject to export prohibitions or licensing requirements. Export prohibitions apply only to scrap metals. Licenses, are required for the export of woods in trunks and pine seeds; numismatic collections considered national treasures; certain biological (species of animals and plants), paleontological, archeological, and ethnographic goods; and raw materials for medicine production. All exports are subject to a general customs processing fee of 0.2 percent. Export contract registration requirements have been abolished as of December 1996.

\section{Payments for and proceeds from invisibles}

111. Residents may freely purchase foreign exchange to make payments for invisible transactions or use foreign exchange balances in their foreign exchange accounts with authorized banks without restriction. Proceeds from invisibles are subject to the same regulations and procedures as those applicable to the proceeds from exports. The importation of foreign currency bank notes is unrestricted, but amounts must be declared by non-residents.

\section{Capital}

112. Inward and outward capital operations are not restricted. Since July 15,1996 , the amount of cash lari that can be taken out of the country by a resident or nonresident without permission is limited to four units of each currency denomination.

\section{Gold}

113. A license is required to conduct both international and domestic trade in gold. 
VIII. TAX SUMMARY (as of June 1, 1998)

\begin{tabular}{|c|c|c|c|}
\hline $\operatorname{Tax}$ & Tax Base and Nature of Tax & Tax Rates & Exemptions and Deductions \\
\hline 1. Value-added tax (VAT) & $\begin{array}{l}\text { Value added is the tax base. Manufacturers are } \\
\text { taxed on basis of the tax credit mechanism, while } \\
\text { retailers and wholesalers pay taxes over the gross } \\
\text { price margin. VAT is calculated on a tax exclusive } \\
\text { basis using as a base the purchase price of } \\
\text { domestically produced goods, while the customs } \\
\text { value plus excise tax of imported goods is taxed. } \\
\text { External trade is taxed according to the destination } \\
\text { principle. For most transactions, VAT becomes } \\
\text { due at the moment of delivery of goods and } \\
\text { services. A threshold applies of lari } 3,000 \text {. }\end{array}$ & $\begin{array}{l}\text { The general rate is } 20 \text { percent. A } \\
7 \text { percent rate applies on } \\
\text { domestically-produced flour. }\end{array}$ & $\begin{array}{l}\text { Exempted from VAT are: primary supply of } \\
\text { agricultural products prior to its industrial processing, } \\
\text { fnancial services; supply and/or import of national } \\
\text { currency, import of gold by the NBG; supply and/or } \\
\text { import of postage stamps; supply of state property } \\
\text { under the privatization program; gods and services } \\
\text { for diplomats; housing rents; sales of confiscated } \\
\text { property and other valuables that the state has } \\
\text { acquired through inheritance or purchase; wheat; } \\
\text { baby food and baby hygienic products; text books } \\
\text { and notebooks for school; insurance and reinsurance; } \\
\text { membership dues for children's hobby groups; } \\
\text { services to the old and disabled; funeral services; } \\
\text { supply and/or import of medicines; medical services; } \\
\text { medical equipment, x-ray films, insulin syringes, } \\
\text { diagnostic testing systems, prosthetic applications, } \\
\text { and technical facilities for the handicapped; re-exports } \\
\text { of goods (via a reimbursement scheme); transit goods; } \\
\text { re-imports of goods; supply and printing of theatre, } \\
\text { circus, movies, symphonic concerts, sport shows and } \\
\text { museum tickets; imports of fixed assets and spare } \\
\text { parts, import of scientific, artistic and literary books } \\
\text { and journals if the authors are citizens of Georgia; } \\
\text { supply of notebooks; supply and/or import of diabetic } \\
\text { food; import of goods for liquidation of natural } \\
\text { disasters; import of pedigree animals and products; } \\
\text { import of goods in an amount that is below the } \\
\text { exempt limit for customs duty; goods produced by the } \\
\text { Georgian Patriarchate's enterprises for religious } \\
\text { purposes and construction an rehabilitation of its } \\
\text { churches; domestic newspapers and magazines; } \\
\text { imports of mazut, electricity and gas; supply of } \\
\text { tourism services to foreign tourists. Agriculture is } \\
\text { exempted from VAT until April l, 1999. }\end{array}$ \\
\hline 2. Excise tax & $\begin{array}{l}\text { Excise taxes are levied on the sales of excisable } \\
\text { goods: spirits, vodka and liquor, champagne and } \\
\text { cognac; grapes and fruit wines, port wines and } \\
\text { their raw materials; beer, tobacco products; cars; } \\
\text { tires; gasoline; carpets; caviar, and jewelry. } \\
\text { Excises are calculated on the purchase price of } \\
\text { domestically produced goods, excluding VAT and } \\
\text { excise, and the import duty inclusive customs } \\
\text { value of imported goods. Cigarettes and alcoholic } \\
\text { beverages are subiect to specific taxes. }\end{array}$ & See Appendix I, Table 22. & $\begin{array}{l}\text { Exempted from excises are: alcoholic beverages } \\
\text { produced by a physical person and used for his } \\
\text { personal consumption; re-exports (subject to a } \\
\text { reimbursement scheme); imports of two liters of } \\
\text { alcoholic beverages and one carton of cigarettes; } \\
\text { goods in transit, goods temporarily imported; and cars } \\
\text { and tires related to humanitarian assistance. Exports } \\
\text { are taxed at a zero rate. }\end{array}$ \\
\hline
\end{tabular}

CInternational Monetary Fund. Not for Redistribution 


\begin{tabular}{|c|c|c|c|}
\hline $\begin{array}{l}\text { 3. Profit and income tax for } \\
\text { enterprises }\end{array}$ & $\begin{array}{l}\text { The tax base is profit defined as income less } \\
\text { production expenses, including depreciation and } \\
\text { wages, of enterprises, their independent branches, } \\
\text { and non-commercial organizations engaging in } \\
\text { commercial activities and residing in Georgia. } \\
\text { Losses can be carried forward for five years. The } \\
\text { allowed depreciation differs by type of asset and } \\
\text { industry. Expedite depreciation is allowed for most } \\
\text { types of assets. }\end{array}$ & The standard rate is 20 percent. & $\begin{array}{l}\text { Exempted from the profit and income tax for } \\
\text { enterprises are: enterprises that are subject to the } \\
\text { presumptive tax, prosthetic and orthopedic } \\
\text { enterprises; profits of companies producing technical } \\
\text { means for the rehabilitation of invalids; profits of the } \\
\text { Georgian patriarchy manufacturing religious articles; } \\
\text { profit of budgetary and charitable organizations; } \\
\text { grants and contributions received by an organization; } \\
\text { profit of international organizations; and the profit of } \\
\text { the National Bank of Georgia. }\end{array}$ \\
\hline 4. Personal income tax & $\begin{array}{l}\text { The annual income of natural persons residing in } \\
\text { Georgia is the tax base, as well as the income of a } \\
\text { nonresident taxpayer with a permanent } \\
\text { establishment in Georgia. }\end{array}$ & $\begin{array}{l}\text { See Appendix I, Table 19. Marginal } \\
\text { rates vary from } 12 \text { percent to } \\
20 \text { percent. }\end{array}$ & $\begin{array}{l}\text { Exempted from personal income tax are: persons } \\
\text { subject to the presumptive tax, invalids from } \\
\text { childhood as well as invalids in blindness groups I } \\
\text { and II; war veterans; women with many children; } \\
\text { single mothers; persons who have received the title of } \\
\text { "Kartvlis Deda" (Mother of Georgia); employment of } \\
\text { a foreign diplomatic employee; social benefits; } \\
\text { revenues from domestic state bonds; alimony; gains } \\
\text { on the supply of intangible property by a physical } \\
\text { person; revenues from the sales of agricultural goods } \\
\text { produced privately; and monetary reimbursement of } \\
\text { the cost of special uniforms for employees of } \\
\text { budgetary organizations. }\end{array}$ \\
\hline 5. Presumptive tax & $\begin{array}{l}\text { Enterprises (entrepeneur) with a turnover lower } \\
\text { than lari } 24,000 \text {. Substitutes income and profit tax } \\
\text { for these enterprises (entrepreneurs). }\end{array}$ & $\begin{array}{l}\text { Depend on the type of business and } \\
\text { location. Oscillates between lari } 300 \\
\text { per month (retail and wholesale } \\
\text { trade in Tbilisi) and lari } 10 \text { per } \\
\text { month (retail trade in booths, in } \\
\text { cities with less than } 30,000 \text { people). }\end{array}$ & None. \\
\hline 6. Trade taxes & $\begin{array}{l}\text { The tax base for customs duties is the customs } \\
\text { value (fob) of imports, including barter trade, from } \\
\text { non-CIS countries. In addition, a processing fee is } \\
\text { levied the customs value (cif) of imports and } \\
\text { exports, and on transshipments. }\end{array}$ & $\begin{array}{l}\text { The uniform customs duty rate is } \\
12 \text { percent. The processing fee is } \\
0.3 \text { percent (increased from } \\
0.2 \text { percent as of July 1996). A } \\
\text { reduced rate } S \text { percent rate applies } \\
\text { on raw materials and certain medical } \\
\text { products. }\end{array}$ & $\begin{array}{l}\text { Exempted from customs duties are: personal imports } \\
\text { up to a value of lari } 300 \text {; goods in transit and re- } \\
\text { exports; capital goods imports under foreign } \\
\text { investment and by joint ventures; non-commercial } \\
\text { imports for cultural institutions; imports of oil } \\
\text { products; baby food; humanitarian aid; and } \\
\text { diplomatic shipments. }\end{array}$ \\
\hline
\end{tabular}




\begin{tabular}{|c|c|c|c|}
\hline 7. Ecology tar & $\begin{array}{l}\text { The ecology tax is levied on polluting activities: the } \\
\text { use of gasoline, diesel fuel, mazut, kerosene, and } \\
\text { liquid gas, as well as the dumping of solid waste, } \\
\text { the dumping of waste in water or the atmosphere, } \\
\text { and the sales of environmentally hazardous } \\
\text { products (i.e. used materials sold for recycling). }\end{array}$ & $\begin{array}{l}\text { The tax is a percentage (damage } \\
\text { factor) of the minimum wage times } \\
\text { the volume of the polluting } \\
\text { substance, where the damage factor } \\
\text { depends on the type of pollution and } \\
\text { whether pollution limits are } \\
\text { exceeded. In the case of sales of } \\
\text { environmentally hazardous products, } \\
\text { the tax depends on the sales price. } \\
\text { Gasoline has a fixed tax of lari } 0.02 \\
\text { per liter, whereas diesel fuel has a } \\
\text { tax of lari } 0.01 \text { per liter. Mazut, } \\
\text { kerosene and liquid gas are subject } \\
\text { to a tax of lari } 0.01 \text { per kilogram. }\end{array}$ & None. \\
\hline 8. Enterprise property tax & $\begin{array}{l}\text { The enterprise property tax is levied on the } \\
\text { assessed value of fixed assets, means of } \\
\text { production, installed equipment, intangible assets, } \\
\text { and uncompleted capital investments of the } \\
\text { enterprise. Excluded from taxation are: } \\
\text { environmental and fire safety facilities; highways; } \\
\text { property of organizations; property of invalids' } \\
\text { associations and enterprises, property that has } \\
\text { been mothballed according to regulations, and } \\
\text { measuring and testing equipment of the territorial } \\
\text { agencies of the DSMCG. }\end{array}$ & 1 percent. & $\begin{array}{l}\text { Exempted from the enterprise property tax are: } \\
\text { budgetary enterprises and organizations, and property } \\
\text { used for educational and cultural purposes. }\end{array}$ \\
\hline 9. Individual property tax & $\begin{array}{l}\text { The individual property tax is levied on the value } \\
\text { of immovable property other than land. }\end{array}$ & $\begin{array}{l}0.1 \text { percent of the value of buildings } \\
\text { and houses. }\end{array}$ & Invalids from childhood and groups I and II invalids. \\
\hline 10. Social security levy & $\begin{array}{l}\text { Social security levies are imposed on money } \\
\text { wages, and are used for the financing of activities } \\
\text { of the SSF and the EF. These extrabudgetary } \\
\text { funds collect the social security levies themselves. }\end{array}$ & $\begin{array}{l}\text { State-owned and private enterprises } \\
\text { pay a } 27 \text { percent levy to the SSF on } \\
\text { the money wages they pay to their } \\
\text { workers and I percent to the EF. } \\
\text { Budgetary organizations pay } 26 \\
\text { percent of their wage bill to the SSF. } \\
\text { Workers pay } 1 \text { percent of their } \\
\text { wages to the SSF. }\end{array}$ & $\begin{array}{l}\text { Amounts paid to persons confined to correctional } \\
\text { institutions; payments for temporary inability to work: } \\
\text { payments paid by organizations out of amounts } \\
\text { received from grants; official employment income of } \\
\text { foreign diplomats; and employment income of } \\
\text { nonresidents if they stay in Georgia for less than } \\
90 \text { days in the taxable year. }\end{array}$ \\
\hline $\begin{array}{l}\text { 11. Tax on ownership of } \\
\text { motor vehicles }\end{array}$ & $\begin{array}{l}\text { Any vehicle included under codes } 8702-8704 \text { of } \\
\text { the nomenclature of goods of foreign economic } \\
\text { activity (light automobiles, buses, and trucks). }\end{array}$ & $\begin{array}{l}\text { Tax rates per horsepower are } \\
\text { lari } 0.25 \text { for light automobiles; } \\
\text { between lari } 1 \text { and } 2 \text { for buses; and } \\
\text { between lari } 0.4 \text { and lari } 4 \text { for } \\
\text { trucks. }\end{array}$ & $\begin{array}{l}\text { Motor vehicles which are technically inoperative; } \\
\text { hand-operated motor vehicles or wheelchairs; and } \\
\text { motor vehicles of war invalids. }\end{array}$ \\
\hline 12. Vehicle cross-border tax & $\begin{array}{l}\text { This tax is levied on vehicles registered abroad } \\
\text { entering Georgia and domestic vehicles } \\
\text { transporting transit trade; the proceeds of this tax } \\
\text { are paid into the Road Fund. }\end{array}$ & $\begin{array}{l}\text { Cars are taxes at US } \$ 20 ; \text { buses } \\
\text { US } \$ 20-130 \text { (depending on number } \\
\text { of seats); and trucks US } \$ 130-300 \\
\text { (depending on tonnage). }\end{array}$ & None. \\
\hline
\end{tabular}

CInternational Monetary Fund. Not for Redistribution 


\begin{tabular}{|c|c|c|c|}
\hline $\begin{array}{l}\text { 13. Tax on transfer of } \\
\text { immovable property }\end{array}$ & $\begin{array}{l}\text { Deeds, lease agreements, and documents certifying } \\
\text { transfer of the right on the ownership of property. } \\
\text { The object of taxation does not include a mortgage } \\
\text { or a security agreement. }\end{array}$ & 2 percent of the taxable amount. & $\begin{array}{l}\text { Lease for a term of less than } 3 \text { years; a transfer to a } \\
\text { spouse, parent, son or daughter, a gratuitous transfer } \\
\text { to the government of charitable organization; a } \\
\text { transfer on the basis of divorce; and a transfer in the } \\
\text { case of reorganization. }\end{array}$ \\
\hline 14. Inheritance and gift tax & $\begin{array}{l}\text { The receipt by a person in the process of } \\
\text { inheritance or by gift from a physical person of any } \\
\text { kind of property. }\end{array}$ & 30 percent. & $\begin{array}{l}\text { Receipt of property by first and second-order heirs } \\
\text { through inheritance or by gift, the property worth of } \\
\text { lari } 50000 \text { received through inheritance; and the } \\
\text { property worth lari } 1000 \text { received through a gift. }\end{array}$ \\
\hline $\begin{array}{l}\text { 15. Tax on transfex of } \\
\text { automobiles }\end{array}$ & Transfer of light cars, buses, or trucks. & 2 percent. & $\begin{array}{l}\text { Registration or re-registration of an automobile by the } \\
\text { importer or by a purchaser when the seller has paid } \\
\text { VAT on the supply of the automobile; transfer to a } \\
\text { spouse, parent or child; transfer upon divorce } \\
\text { decision; gratuitous transfers to the government or to } \\
\text { a charitable organization; and transfer in a } \\
\text { reorganization. }\end{array}$ \\
\hline 16. Land tax & $\begin{array}{l}\text { Tax levied on cultivated land, including pastures, } \\
\text { and on land that could be cultivated. }\end{array}$ & $\begin{array}{l}\text { For arable and agricultural land used } \\
\text { for perennial crops, tax rates vary } \\
\text { from lari } 6 \text { per hectare to lari } 44 \text { per } \\
\text { hectare, depending on the use, } \\
\text { quality, and location of the land. For } \\
\text { meadows and pastures, the tax rate } \\
\text { oscillates between lari } 1 \text { and lari } 6 \\
\text { per hectare. }\end{array}$ & None. \\
\hline $\begin{array}{l}\text { 17. Tax on nonagricultural } \\
\text { land }\end{array}$ & $\begin{array}{l}\text { A plot of land that does not belong to agricultural } \\
\text { lands. }\end{array}$ & $\begin{array}{l}\text { Differentiated according to location } \\
\text { and zones, the annual base is } \\
\text { determined as } 0.24 \text { lari per square } \\
\text { meter. }\end{array}$ & $\begin{array}{l}\text { Exempted from the tax on nonagricultural land are } \\
\text { plots of state-owned land occupied by: budget } \\
\text { organizations, sporting and health complexes, } \\
\text { scientific institutes, religious institutions, public-use } \\
\text { lands, invalids of the World War II, new settlements, } \\
\text { electrical stations. }\end{array}$ \\
\hline 18. Natural resources tax & $\begin{array}{l}\text { Tax on the volume of extracted mineral resources, } \\
\text { timber, wild plants, water, and wild animal } \\
\text { resources. }\end{array}$ & $\begin{array}{l}\text { Tax rates vary from } 1 \text { percent to } \\
10 \text { percent of the price of mineral } \\
\text { resources. For timber, the tax rate } \\
\text { oscillates between } 1 \text { and } 34 \text { percent } \\
\text { of the price. For water, the tax rate } \\
\text { oscillates between } 1 \text { and } 15 \text { percent. } \\
\text { For animals and plants, the tax rate } \\
\text { oscillates between } 1 \text { and } 55 \text { percent } \\
\text { of the market price of the resource. }\end{array}$ & $\begin{array}{l}\text { Exempted from the natural resources tax are the } \\
\text { natural resources connected with protection and } \\
\text { restoration works, as well as the construction of } \\
\text { underground stations, water supply, sewerage system, } \\
\text { and underground constructions. }\end{array}$ \\
\hline $\begin{array}{l}\text { 19. Tax on entrepreneurial } \\
\text { activity }\end{array}$ & $\begin{array}{l}\text { Local tax on entrepreneurs (physical and legal } \\
\text { person). }\end{array}$ & $\begin{array}{l}\text { The tax rate cannot exceed } 1 \text { percent } \\
\text { of the revenues received from the } \\
\text { supply of VAT exclusive goods. }\end{array}$ & None. \\
\hline
\end{tabular}

CInternational Monetary Fund. Not for Redistribution 


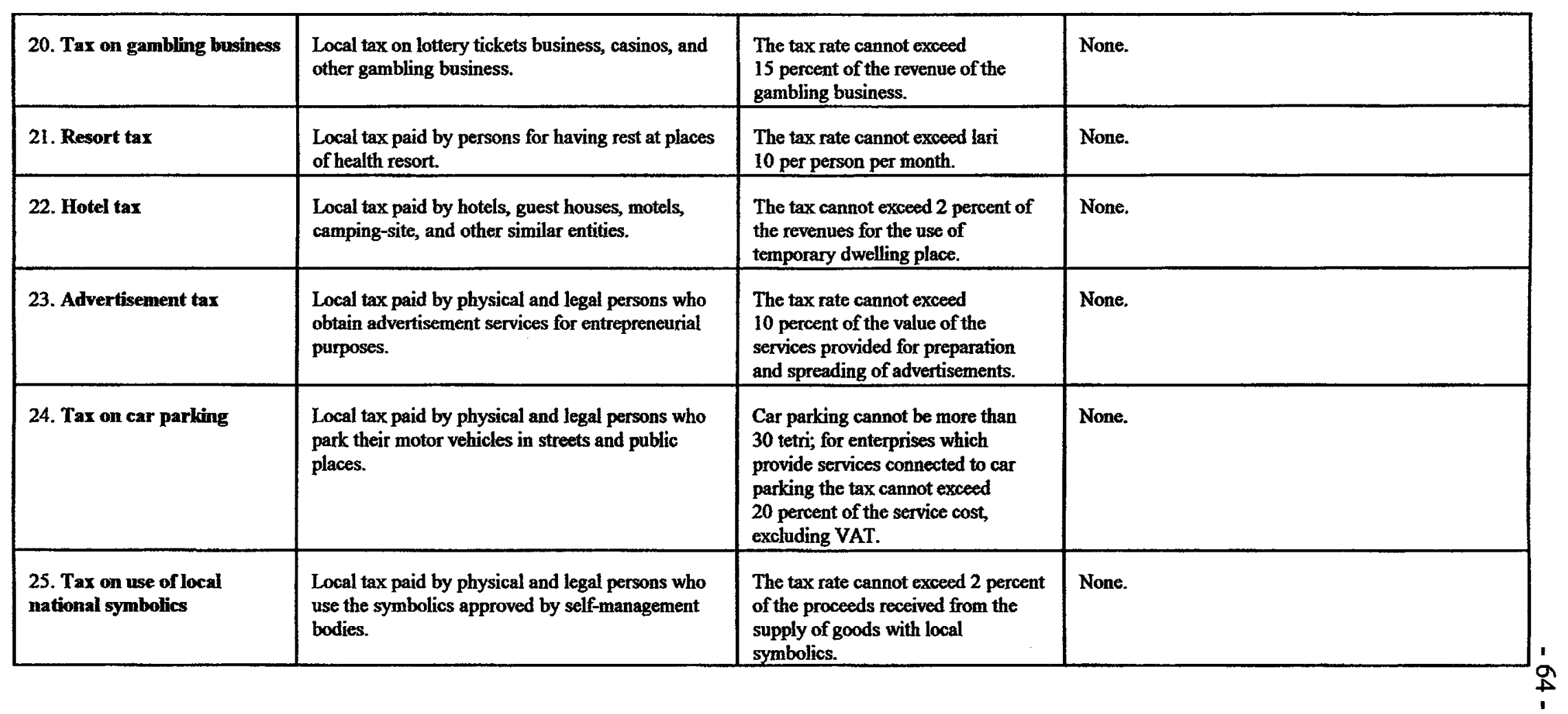


Table 9. Georgia: GDP by Origin, 1992-97

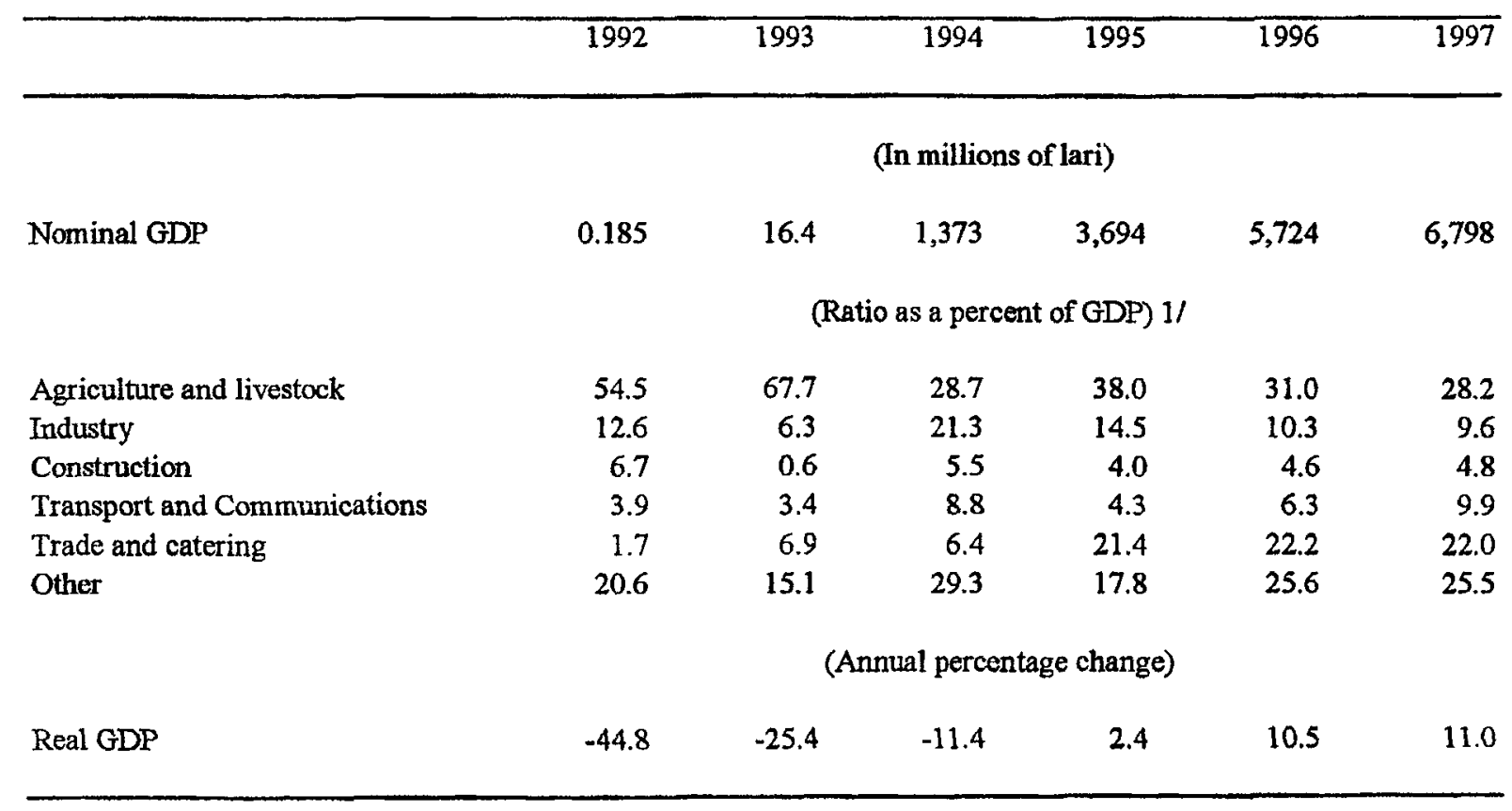

Sources: Data provided by the State Department of Statistics; and IMF staff estimates.

1/ The data for 1994-97 are not comparable with earlier years because they include official estimates for the informal sector. Such estimates are subject to large margins of error. 
Table 10. Georgia: Transportation by State Enterprises, 1992-97 (Thousands of tons)

\begin{tabular}{lrrrrrr}
\hline & 1992 & 1993 & 1994 & 1995 & 1996 & 1997 \\
& & & & & & \\
Freight transport & 47,099 & 23,045 & 14,617 & 14,984 & 14,123 & 17,820 \\
Rail & 14,633 & 7,966 & 3,173 & 4,656 & 4,784 & 6,480 \\
Road & 26,545 & 10,416 & 8,168 & 8,690 & 8,777 & 11,160 \\
Sea & 5,921 & 4,663 & 3,276 & 1,638 & 562 & 180 \\
& & & & & & \\
\hline
\end{tabular}

Source: State Department of Statistics. 
Table 11. Georgia: Population and Employment, 1992-97

(In thousands)

\begin{tabular}{|c|c|c|c|c|c|c|}
\hline & 1992 & 1993 & 1994 & 1995 & 1996 & 1997 \\
\hline Total population $1 /$ & $5,412.4$ & $5,397.7$ & $5,383.0$ & $5,374.3$ & $5,377.2$ & $\ldots$ \\
\hline Males & $2,578.3$ & $2,573.3$ & $\ldots$ & $\ldots$ & $\ldots$ & $\ldots$ \\
\hline Females & $2,834.1$ & $2,824.4$ & $\ldots$ & $\ldots$ & $\ldots$ & $\ldots$ \\
\hline Urban & $3,014.9$ & $2,998.4$ & $2,978.2$ & $2,369.2$ & $2,969.0$ & $\ldots$ \\
\hline Rural & $2,397.6$ & $2,393.3$ & $2,404.8$ & $2,405.1$ & $2,408.2$ & $\ldots$ \\
\hline Under 16 years of age & $1,395.3$ & $1,368.5$ & $\ldots$ & $\ldots$ & $\ldots$ & $\ldots$ \\
\hline In active years $2 /$ & $3,014.1$ & $3,000.9$ & $\ldots$ & $\ldots$ & $\ldots$ & $\cdots$ \\
\hline Over active age & $1,003.0$ & $1,028.3$ & $\ldots$ & $\cdots$ & $\cdots$ & $\cdots$ \\
\hline Population employed 3/ & $1,984.2$ & $1,792.0$ & $1,749.7$ & $1,730.0$ & $2,036.2$ & $2,233.2$ \\
\hline State sector & $1,375.6$ & $1,160.0$ & $1,095.7$ & 985.3 & 580.0 & 568.6 \\
\hline of which: & & & & & & \\
\hline Industry and construction & 422.1 & 337.1 & 278.1 & 251.7 & 138.8 & 123.0 \\
\hline Agriculture & 160.3 & 113.6 & 107.4 & 90.0 & 42.2 & 33.5 \\
\hline $\begin{array}{l}\text { Transportation and } \\
\text { communications }\end{array}$ & 72.4 & 97.8 & 98.7 & 78.1 & 68.6 & 65.2 \\
\hline $\begin{array}{l}\text { Trade and other } \\
\text { materials sectors }\end{array}$ & 64.1 & 85.0 & 56.8 & 41.1 & 39.2 & 31.8 \\
\hline $\begin{array}{l}\text { Health, education, } \\
\text { and science } \\
\text { Administration and }\end{array}$ & 438.2 & 413.3 & 315.4 & 211.1 & 215.5 & 227.1 \\
\hline finance & 50.2 & 59.7 & 45.3 & 44.1 & 35.3 & 41.3 \\
\hline Other nonmaterial sector & 98.3 & 53.6 & 78.2 & 76.4 & 40.4 & 46.7 \\
\hline Cooperatives $4 /$ & 197.1 & 143.7 & 94.0 & 110.7 & 55.4 & 47.0 \\
\hline Industry and construction & 64.9 & 25.6 & 24.0 & 40.1 & 27.4 & 23.4 \\
\hline Agriculture & 78.1 & 60.9 & 48.1 & 40.3 & 24.4 & 22.0 \\
\hline Other & 54.1 & 57.2 & 21.9 & 30.3 & 3.6 & 1.6 \\
\hline Private sector & 411.5 & 488.2 & 560.0 & 634.0 & $1,400.7$ & $1,617.6$ \\
\hline of which: self-employed & 4.4 & 5.0 & 5.0 & 6.4 & $1,324.4$ & $1,529.2$ \\
\hline Retired (receiving pension) & $1,079.6$ & $1,139.6$ & $1,140.8$ & $1,140.7$ & $1,104.7$ & $1,022.0$ \\
\hline of which: retirees employed & 182.4 & 118.6 & 93.0 & 65.2 & 65.1 & 64.7 \\
\hline
\end{tabular}

Source: State Department of Statistics.

1/ Total population may be significantly overestimated because data include persons registered in Georgia but living abroad.

2/ Since February 20,1996 , working age is $16-60$ for women, and 16-65 years for men. Prior to that date, working age was $16-55$ for women, and 16-60 years for men.

3/ Excludes employment in the informal sector. Official estimates indicate that, as of end-1997 employment on the informal sector was about 750,000 persons.

4/ Including collective farms and consumer cooperatives. 
Table 12. Georgia: Unemployment, 1992-97

(Number of persons, end of period)

\begin{tabular}{lrrrrrrr}
\hline & 1992 & 1993 & 1994 & 1995 & 1996 & 1997 \\
\hline $\begin{array}{l}\text { Registered unemployed } \\
\begin{array}{l}\text { Of which: } \\
\text { Receiving benefits }\end{array}\end{array}$ & 136,402 & 225,886 & 75,714 & 65,450 & 53,372 & 142,795 \\
\hline
\end{tabular}

Sources: Ministry of Labor and Social Affairs and State Department of Statistics. 
Table 13. Georgia: Average Monthly Wages, 1992-97 1/2/ (In lari)

\begin{tabular}{|c|c|c|c|c|c|c|}
\hline & 1992 & 1993 & 1994 & 1995 & 1996 & 1997 \\
\hline Total economy & 0.002 & 0.028 & 6.2 & 13.8 & 29.0 & 54.9 \\
\hline Industry & 0.002 & 0.041 & 9.6 & 19.4 & 50.3 & 74.8 \\
\hline Workers & 0.002 & 0.037 & 8.5 & 17.4 & 31.0 & 46.1 \\
\hline Agriculture & 0.001 & 0.016 & 1.4 & 4.6 & 10.0 & 13.3 \\
\hline State farms, agricultural enterprises & 0.001 & 0.017 & 1.1 & 3.2 & 7.4 & 12.1 \\
\hline Construction & 0.002 & 0.046 & 12.6 & 38.8 & 73.7 & 94.3 \\
\hline Workers & 0.002 & 0.045 & 17.3 & 45.0 & 87.1 & 103.1 \\
\hline Transportation & 0.001 & 0.052 & 9.3 & 32.5 & 68.3 & 85.5 \\
\hline Railway transportation & 0.002 & 0.061 & 10.5 & 37.0 & 53.5 & 74.5 \\
\hline Waterway transportation & 0.003 & 0.094 & 9.9 & 44.0 & 42.9 & 96.4 \\
\hline Urban transportation & 0.001 & 0.036 & 13.2 & 68.0 & 96.9 & 98.9 \\
\hline Communications & 0.002 & 0.036 & 6.5 & 25.4 & 43.2 & 57.7 \\
\hline Trade and distribution & 0.001 & 0.012 & 2.7 & 15.7 & 17.7 & 37.8 \\
\hline Computer services & 0.002 & 0.028 & 3.6 & 19.7 & 20.6 & 26.4 \\
\hline Housing and communal services & 0.001 & 0.028 & 8.8 & 18.8 & 34.0 & 59.1 \\
\hline \multicolumn{7}{|l|}{ Public health and social } \\
\hline $\begin{array}{l}\text { security } \\
\text { Public education }\end{array}$ & $\begin{array}{l}0.001 \\
0.001\end{array}$ & $\begin{array}{l}0.015 \\
0.013\end{array}$ & $\begin{array}{l}1.0 \\
1.2\end{array}$ & $\begin{array}{l}5.5 \\
7.0\end{array}$ & $\begin{array}{l}15.4 \\
14.6\end{array}$ & $\begin{array}{l}20.2 \\
36.5\end{array}$ \\
\hline Culture & 0.001 & 0.019 & 1.1 & 4.0 & 15.9 & 28.3 \\
\hline Art & 0.001 & 0.021 & 1.8 & 5.9 & 25.6 & 54.8 \\
\hline Science and related services & 0.001 & 0.023 & 1.7 & 9.5 & 24.3 & 32.1 \\
\hline \multicolumn{6}{|l|}{ Credit and state insurance } & 97.1 \\
\hline \multicolumn{4}{|l|}{ State administration and } & 10.4 & 38.6 & 71.7 \\
\hline \multicolumn{7}{|l|}{ Memorandum items: } \\
\hline \multicolumn{7}{|l|}{ Average annual salary } \\
\hline Total economy & 0.018 & 0.335 & 73.8 & 163.2 & 348.0 & 658.8 \\
\hline Industry & 0.022 & 0.494 & 115.7 & 232.8 & 603.6 & 897.6 \\
\hline Agriculture & 0.010 & 0.188 & 16.3 & 55.2 & 120.0 & 159.6 \\
\hline Services $3 /$ & 0.023 & 0.354 & $\ldots$ & $\ldots$ & $\ldots$ & $\ldots$ \\
\hline
\end{tabular}

Source: State Department of Statistics.

1/ Wages include all cash, compensation, and value of goods-in-kind.

$2 /$ These data are subject to large margins of error.

$3 /$ Average for all services. 
Table 14. Georgia: Government Wages and Pensions, 1995-97 1/

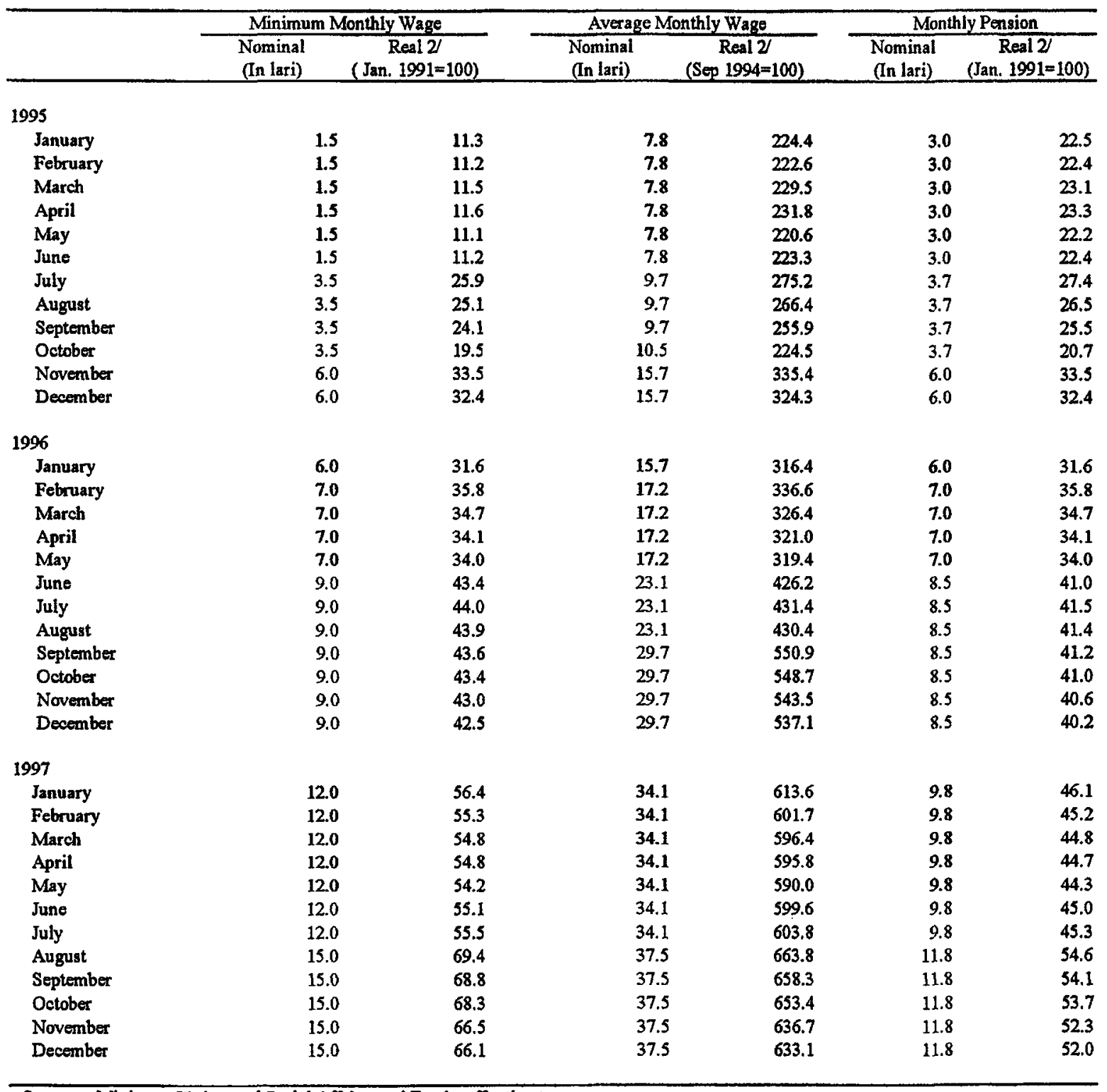

Sources: Ministry of Labor and Social Affairs; and Fund staff estimates.

1/ Includes only wages of budgetary organizations.

$2 /$ The pension and minimum nominal wage are deflated by the CPI. 
Table 15. Georgia: Consumer Price Index in Tbilisi, 1994-97 1/2/

\begin{tabular}{|c|c|c|c|c|}
\hline & \multirow{2}{*}{$\begin{array}{c}\text { Consumer } \\
\text { Price } \\
\text { Index } \\
(1995=100) \\
\end{array}$} & \multicolumn{3}{|c|}{ Percentage Changes } \\
\hline & & $\begin{array}{c}\text { Over } \\
\text { Previous } \\
\text { Month }\end{array}$ & $\begin{array}{l}\text { Over } \\
\text { Previous } \\
\text { Quarter }\end{array}$ & $\begin{array}{c}\text { Over Same } \\
\text { Month } \\
\text { Last Year }\end{array}$ \\
\hline \multicolumn{5}{|l|}{1994} \\
\hline January & 3.3 & 168.4 & & $15,973.0$ \\
\hline February & 4.4 & 35.1 & & $15,750.1$ \\
\hline March & 6.7 & 50.2 & 444.6 & $20,819.9$ \\
\hline April & 12.3 & 84.4 & & $30,835.2$ \\
\hline May & 17.5 & 42.7 & & $33,393.6$ \\
\hline June & 16.6 & -5.0 & 150.0 & $24,133.8$ \\
\hline July & 17.7 & 6.2 & & $18,309.3$ \\
\hline August & 30.2 & 71.0 & & $24,436.2$ \\
\hline September & 94.1 & 211.2 & 465.1 & $50,669.1$ \\
\hline October & 86.2 & -8.4 & & $27,864.2$ \\
\hline November & 87.5 & 1.5 & & 11.846 .0 \\
\hline December & 80.4 & -8.1 & -14.6 & 6.473 .9 \\
\hline Average 1994 & 38.1 & $\cdots$ & $\cdots$ & $15,606.5$ \\
\hline \multicolumn{5}{|l|}{1995} \\
\hline January & 90.8 & 13.0 & & $2,667.9$ \\
\hline February & 91.5 & 0.8 & & $1,965.2$ \\
\hline March & 88.8 & -3.0 & 10.5 & $1,233.7$ \\
\hline April & 87.9 & -1.0 & & 616.0 \\
\hline May & 92.4 & 5.1 & & 427.4 \\
\hline June & 91.3 & -1.2 & 2.8 & 448.5 \\
\hline July & 92.1 & 0.9 & & 421.0 \\
\hline August & 95.1 & 3.3 & & 214.7 \\
\hline September & 99.0 & 4.1 & 8.5 & 5.3 \\
\hline October & 122.2 & 23.4 & & 41.8 \\
\hline November & 122.3 & 0.1 & & 39.9 \\
\hline December & 126.5 & 3.4 & 27.7 & 57.4 \\
\hline Average 1995 & 100.0 & $\ldots$ & $\ldots$ & 162.7 \\
\hline \multicolumn{5}{|l|}{1996} \\
\hline January & 129.6 & 2.5 & & 42.8 \\
\hline February & 133.5 & 3.0 & & 45.9 \\
\hline March & 137.7 & 3.1 & 8.8 & 55.0 \\
\hline April & 140.0 & 1.7 & & 59.3 \\
\hline May & 140.7 & 0.5 & & 52.3 \\
\hline June & 141.4 & 0.5 & 2.7 & 54.9 \\
\hline July & 139.7 & -1.2 & & 51.7 \\
\hline August & 140.1 & 0.2 & & 47.2 \\
\hline September & 140.9 & 0.6 & -0.4 & 42.2 \\
\hline October & 141.4 & 0.4 & & 15.7 \\
\hline November & 142.8 & 1.0 & & 16.7 \\
\hline December & 144.5 & 1.2 & 2.6 & 14.2 \\
\hline Average 1996 & 139.4 & $\ldots$ & $\ldots$ & 39.4 \\
\hline \multicolumn{5}{|l|}{1997} \\
\hline January & 145.2 & 0.5 & & 12.0 \\
\hline February & 148.1 & 2.0 & & 10.9 \\
\hline March & 149.4 & 0.9 & 3.4 & 8.5 \\
\hline April & 149.6 & 0.1 & & 6.8 \\
\hline May & 151.0 & 1.0 & & 7.3 \\
\hline June & 148.6 & .1 .6 & -0.5 & 5.1 \\
\hline July & 147.6 & -0.7 & & 5.6 \\
\hline August & 147.6 & 0.0 & & 5.4 \\
\hline September & 148.8 & 0.8 & 0.2 & 5.7 \\
\hline October & 150.0 & 0.8 & & 6.0 \\
\hline November & 153.9 & 2.6 & & 7.8 \\
\hline December & 154.8 & 0.6 & 4.0 & 7.1 \\
\hline Average 1997 & 149.5 & $\ldots$ & $\ldots$ & 7.3 \\
\hline
\end{tabular}

1/ According to 295-good Laspeyres index. The last revision of the CPI weights was made in December 1994.

2/ A national consumer price index (CPI) was introduced in January 1996. Developments in the national CPI during 1996 and 1997 have been virtually identical to the developments in the Thilisi CPI. 
Table 16. Georgia: Summary of General Government Operations, 1995-1997

\begin{tabular}{|c|c|c|c|c|c|c|c|c|c|}
\hline & \multicolumn{3}{|c|}{1995} & \multicolumn{3}{|c|}{1996} & \multicolumn{3}{|c|}{1997} \\
\hline & Jan.-Jun. & Jul.-Dec. & Year & Jan.-Jun. & Jul.-Dec. & Year & Jan-Jun. & July-Dec. & Year \\
\hline & \multicolumn{9}{|c|}{ (In millions of lari) } \\
\hline Total Revenues and Grants & 95.4 & 165.5 & 260.9 & 233.4 & 303.4 & 536.8 & 282.6 & 421.8 & 704.4 \\
\hline Total Revenue & 71.2 & 118.8 & 189.9 & 192.5 & 273.2 & 465.7 & 276.6 & 402.2 & 678.8 \\
\hline Tax revenue (excluding extrabudgetary) & 51.8 & 80.1 & 131.9 & 117.5 & 187.1 & 304.5 & 204.0 & 280.6 & 484.6 \\
\hline Taxes on income & 7.1 & 13.7 & 20.9 & 16.8 & 27.7 & 44.5 & 32.2 & 44.7 & 76.9 \\
\hline Taxes on profits & 13.5 & 15.1 & 28.6 & 16.0 & 21.9 & 37.9 & 18.8 & 20.0 & 38.8 \\
\hline VAT & 20.7 & 37.7 & 58.5 & 51.2 & 82.7 & 133.8 & 84.6 & 120.9 & 205.5 \\
\hline Custom duties & 2.3 & 2.3 & 4.5 & 7.9 & 12.0 & 19.9 & 20.6 & 40.6 & 61.2 \\
\hline Other taxes $1 /$ & 9.0 & 11.2 & 20.3 & 28.5 & 53.3 & 81.8 & 47.8 & 54.4 & 102.2 \\
\hline Nontax revenue & 5.7 & 11.2 & 16.9 & 20.5 & 29.5 & 50.0 & 21.7 & 46.1 & 67.8 \\
\hline Extrabudgetary revenue 2 / & 13.7 & 27.5 & 41.2 & 54.5 & 56.7 & 111.2 & 50.9 & 75.5 & 126.4 \\
\hline Grants & 24.2 & 46.7 & 71.0 & 40.9 & 30.2 & 71.1 & 6.0 & 19.6 & 25.6 \\
\hline Total expenditure and net lending & 195.6 & 259.8 & 455.4 & 340.1 & 456.3 & 796.4 & 417.4 & 567.3 & 984.7 \\
\hline Total expenditure & 177.8 & 250.3 & 428.1 & 340.1 & 465.2 & 805.3 & 417.4 & 560.8 & 978.2 \\
\hline Current expenditure & 135.3 & 183.6 & 319.2 & 313.8 & 422.6 & 736.4 & 382.5 & 522.3 & 904.8 \\
\hline Wages and salaries & 26.4 & 33.1 & 59.5 & 43.7 & 59.9 & 103.7 & 73.6 & 81.9 & 155.5 \\
\hline Other goods and services & 23.3 & 32.8 & 56.1 & 48.1 & 72.1 & 120.1 & 45.3 & 73.2 & 118.5 \\
\hline Transfers & 16.6 & 22.5 & 39.1 & 29.7 & 29.3 & 59.0 & 40.2 & 63.2 & $\$ 03.4$ \\
\hline Interest payments & 27.3 & 27.3 & 54.6 & 24.6 & 32.6 & 57.8 & 40.3 & 52.1 & 92.4 \\
\hline Domestic & 0.1 & 0.9 & 1.0 & 2.8 & 8.9 & 11.7 & 17.3 & 20.7 & 38.0 \\
\hline External & 27.2 & 26.4 & 53.6 & 22.0 & 23.9 & 45.9 & 23.1 & 31.3 & 54.4 \\
\hline Other current expenditures 3 / & 19.6 & 30.1 & 49.7 & 47.9 & 53.4 & 101.4 & 51.2 & 57.1 & 108.3 \\
\hline Unclassified expenditure & 2.0 & 8.5 & 10.4 & 26.8 & 55.6 & 82,4 & 17.3 & 36.8 & 54.1 \\
\hline Extrabudgetary expenditures 4/ & 20.1 & 29.8 & 49.9 & 47.2 & 56.6 & 103.8 & 66.8 & 101.6 & 168.4 \\
\hline Local government expenditures & 23.4 & 46.6 & 70.1 & 45.7 & 63.0 & 108.7 & 47.8 & 56.4 & 104.2 \\
\hline Capital expenditure & 19.1 & 19.7 & 38.8 & 26.3 & 42.6 & 68.9 & 34.9 & 38.5 & 73.4 \\
\hline Net lending & 17.8 & 9.5 & 27.3 & $\cdots$ & .8 .9 & -8.9 & 0.0 & 6.5 & 6.5 \\
\hline Overall balance (commitments) & -100.2 & .94 .3 & -194.5 & -106.8 & -152.9 & -259.6 & -134.8 & -145.5 & -280.3 \\
\hline Expenditure arrears (-, reduction) & 32.5 & -5.7 & 26.8 & 3.0 & 5.0 & 8.0 & 5.2 & 18.6 & 23.8 \\
\hline Bxternal interest & 6.4 & 5.6 & 12.0 & 2.1 & -7.2 & -5.1 & -11.2 & -3.0 & -14.2 \\
\hline Other & 26.1 & -11.3 & 14.8 & 0.9 & 12.2 & 13.0 & 16.4 & 21.6 & 38.0 \\
\hline Overall balance (cash) & -67.7 & -100.0 & -167.7 & -103.8 & -147.9 & .251 .6 & -129.6 & -126.9 & -256.5 \\
\hline Total financing & 67.7 & 100.0 & 167.7 & 103.8 & 147.9 & 251.6 & 129.6 & 126.9 & 256.5 \\
\hline Domestic & 27.1 & 32.4 & 59.4 & 57.6 & 99.2 & 156.8 & 120.0 & 41.6 & 161.6 \\
\hline External & 40.6 & 67.6 & 108.2 & 46.1 & 48.7 & 94.8 & 9.6 & 85.3 & 94.9 \\
\hline Disbursements & 40.6 & 67.6 & 108.2 & 46.1 & 48.7 & 94.9 & 8.3 & 82.0 & 90.3 \\
\hline Amortization & 0.0 & -116.5 & -116.5 & -15.5 & $\ldots$ & -15.5 & .62 .9 & -5.6 & -68.5 \\
\hline Changes in arrears (-, reduction) & 0.0 & 116.5 & 116.5 & 15.5 & $\ldots$ & 15.5 & $\$ 6.2$ & -0.2 & 56.0 \\
\hline Macroeconomic support & 0.0 & 0.0 & 0.0 & $\ldots$ & $\ldots$ & 0.0 & 7.9 & 9.2 & 17.1 \\
\hline
\end{tabular}

Sources: Data provided by the Georgian authorities; and staff estimates. 
Table 16. (concluded) Georgia: Summary of General Government Operations, 1995-1997

\begin{tabular}{|c|c|c|c|c|c|c|c|c|c|}
\hline & \multicolumn{3}{|c|}{1995} & \multicolumn{3}{|c|}{1996} & \multicolumn{3}{|c|}{1997} \\
\hline & Jan.-Jun. & Jul.-Dec. & Year & Jan.-Jun. & Dec. & Year & Jan.-Jun. & Jul.-Dec. & Year \\
\hline Ratios to GDP & \multicolumn{9}{|c|}{ (In percent) } \\
\hline Total Revenues and Grants & 6.1 & 7.7 & 7.1 & 8.3 & 10.5 & 9.4 & 9.0 & 11.6 & 10.4 \\
\hline Total Revenue & 4.6 & 5.6 & 5.1 & 6.8 & 9.4 & 8.1 & 8.8 & 11.0 & 10.0 \\
\hline Tex revenue (including extrabudgetary) & 4.2 & 5.0 & 4.7 & 6.1 & 8.4 & 7.3 & 8.1 & 9.8 & 9.0 \\
\hline Tax revenue (oxcluding exirabudgetary) & 3.3 & 3.7 & 3.6 & 4.2 & 6.5 & 5.3 & 6.5 & 7.7 & -7.1 \\
\hline Total expenditure & 11.4 & 11.7 & 11.6 & 12.0 & 16.1 & 14.1 & 13.2 & 15.4 & 14.4 \\
\hline Total expenditure and net lending & 12.6 & 12.1 & 12.3 & 12.0 & 15.8 & 13.9 & 13.2 & 15.6 & 14.5 \\
\hline Current expenditure & 8.7 & 8.6 & 8.6 & 11.1 & 14.6 & 12.9 & 12.1 & 14.3 & 13.3 \\
\hline Total revenue minus current expenditure & -4.1 & -3.0 & -3.5 & -4.3 & -5.2 & -4.7 & -3.4 & -3.3 & -4.1 \\
\hline Balance (commitments) & -6.4 & -4.4 & -5.3 & -3.8 & -5.3 & -4.5 & -4.3 & -4.0 & -4.1 \\
\hline Balance (cash) & -4.4 & -4.7 & -4.5 & -3.7 & -5.1 & -4.4 & -4.1 & -3.5 & -3.8 \\
\hline \multicolumn{10}{|l|}{ Other ratios } \\
\hline Total revenue/Current expenditure & 52.6 & 64.7 & 59.5 & 61.3 & 64.6 & 63.2 & 72.3 & 77.0 & 75.0 \\
\hline Total revenue and grants/Total expenditure & 53.7 & 66.1 & 60.9 & 68.6 & 65.2 & 66.7 & 67.7 & 75.2 & 72.0 \\
\hline Total Revenue/Total exp.and net lending & 36.4 & 45.7 & 41.7 & 56.6 & 59.9 & 58.5 & 66.3 & 70.9 & 68.9 \\
\hline Balance(cash)/Total exp. and net lending & -34.6 & -38.5 & .36 .8 & -30.5 & -32.4 & -31.6 & -31.0 & -22.4 & -26.0 \\
\hline Balance (accrual)/Total exp. and net lending & -51.2 & -36.3 & -42.7 & .31 .4 & -33.5 & -32.6 & -32.3 & -25.6 & -28.5 \\
\hline Total revenue/Current expenditure & 52.6 & 64.7 & 59.5 & 61.3 & 64.6 & 63.2 & 72.3 & 77.0 & 75.0 \\
\hline
\end{tabular}

Sources: Data provided by the Georgian authorities; and staff estimates.

$1 /$ Includes the land tax, enterprise property taxes, the presurnptive tax, the ecological tax.

2/Includes revenues of the Pension Fund, the Employment Fund, the Health Fund (until July, 1997), the Privatization Fund, and the Road Fund. 3/Includes, among others, Health Fund outlays, counterpart of settlement in-kind to Turkrtenistan for pre-1995 debt, expenditures on Georgia's embassies abroad and business travel costs for government employees.

4/ Outlays on pensions and unemployment benefits; Health Fund outiays are classified under "other current expenditure"; Road Fund's expenditures aro classified under capital outlays. 
Table 17. Georgia: Sunmary of Govemment General Operations (In percent of GDP)

\begin{tabular}{|c|c|c|c|c|c|c|c|c|c|}
\hline & \multicolumn{3}{|c|}{1995} & \multicolumn{3}{|c|}{1996} & \multicolumn{3}{|c|}{1997} \\
\hline & Jan.-Jun. & Jul.-Dec. & Year & Jan.-Jun. & Jul.-Dec. & Year & Jan.-Jun. & Jul.-Dec. & Year \\
\hline Total Revenues and Grants & 5.7 & 8.2 & 7.1 & 8.3 & 10.5 & 9.4 & 9.0 & 11.6 & 10.4 \\
\hline Total Revenue & 4.2 & 5.9 & 5.1 & 6.8 & 9.4 & 8.1 & 8.8 & 11.0 & 10.0 \\
\hline Tax revenue (excluding extrabudgetary) & 3.1 & 4.0 & 3.6 & 4.2 & 6.5 & 5.3 & 6.5 & 7.7 & 7.1 \\
\hline Taxes on income & 0.4 & 0.7 & 0.6 & 0.6 & 1.0 & 0.8 & 1.0 & 1.2 & 1.1 \\
\hline Taxes on profits & 0.8 & 0.8 & 0.8 & 0.6 & 0.8 & 0.7 & 0.6 & 0.5 & 0.6 \\
\hline VAT & 1.2 & 1.9 & 1.6 & 1.8 & 2.9 & 2.3 & 2.7 & 3.3 & 3.0 \\
\hline Custom duties & 0.1 & 0.1 & 0.1 & 0.2 & 0.4 & 0.3 & 0.7 & 1.1 & 0.9 \\
\hline Other taxes & 0.5 & 0.6 & 0.5 & 0.9 & 1.8 & 1.4 & 1.5 & 1.5 & 1.5 \\
\hline Nontax revenue & 0.3 & 0.6 & 0.5 & 0.7 & 1.0 & 0.9 & 0.7 & 1.3 & 1.0 \\
\hline Extrabudgetary revenue & 0.8 & 1.4 & 1.1 & 1.9 & 2.0 & 1.9 & 1.6 & 2.1 & 1.9 \\
\hline Grants & 1.4 & 2.3 & 1.9 & 1.5 & 1.0 & 1.2 & 0.1 & 0.5 & 0.4 \\
\hline Total expenditure and net lending & 11.6 & 12.9 & 12.3 & 12.0 & 15.7 & 13.9 & 13.2 & 15.6 & 14.5 \\
\hline Total expenditure & 10.6 & 12.4 & 11.6 & 12.0 & 16.1 & 14.1 & 13.2 & 15.4 & 14.4 \\
\hline Current expenditure & 8.1 & 9.1 & 8.6 & 11.1 & 14.6 & 12.9 & 12.1 & 14.3 & 13.3 \\
\hline Wages and salaries & 1.6 & 1.6 & 1.6 & 1.5 & 2.1 & 1.8 & 2.3 & 2.2 & 2.3 \\
\hline Other goods and services & 1.4 & 1.6 & 1.5 & 1.7 & 2.5 & 2.1 & 1.4 & 2.0 & 1.7 \\
\hline Subsidies and transfers & 0.9 & 1.2 & 1.1 & 1.1 & 1.0 & 1.0 & 1.3 & 1.7 & 1.5 \\
\hline Interest payments & 1.6 & 1.4 & 1.5 & 1.0 & 1.0 & 1.0 & 1.3 & 1.4 & 1.4 \\
\hline Other current expenditures & 1.2 & 1.5 & 1.3 & 1.7 & 1.8 & 1.8 & 1.6 & 1.6 & 1.6 \\
\hline Unclassified expenditure & 0.1 & $\ldots$ & 0.3 & 0.9 & 1.9 & 1.4 & 0.5 & 1.0 & 0.8 \\
\hline Extrabudgetary expenditures & 1.2 & 1.5 & 1.4 & 1.7 & 2.0 & 1.8 & 2.1 & 2.8 & 2.5 \\
\hline Local government expenditures & 1.4 & 2.3 & 1.9 & 1.6 & 2.2 & 1.9 & 1.5 & 1.5 & 1.5 \\
\hline Capitsl expenditure & 1.1 & 1.0 & 1.1 & 0.9 & 1.5 & 1.2 & 1.1 & 1.1 & 1.1 \\
\hline Net lending & 1.1 & $\ldots$ & 0.7 & 0.0 & -0.3 & -0.2 & 0.0 & 0.2 & 0.1 \\
\hline Overall balance (commitments) & -6.0 & -4.7 & .5 .3 & -3.8 & -5.3 & -4.5 & -4.3 & -3.8 & .4 .1 \\
\hline Expenditure arrears (-, reduction) & 1.9 & -0.3 & 0.7 & 0.1 & 0.2 & 0.1 & 0.2 & 0.5 & 0.4 \\
\hline External interest & 0.4 & $\ldots$ & 0.3 & 0.1 & -0.2 & -0.1 & -0.4 & -0.1 & .0 .2 \\
\hline Other & 1.6 & -0.6 & 0.4 & $\ldots$ & 0.4 & 0.2 & 0.5 & 0.6 & 0.6 \\
\hline Overall balance (cash) & -4.0 & -5.0 & -4.5 & -3.7 & -5.1 & -4.4 & -4.1 & -3.3 & -3.8 \\
\hline Financing & 4.0 & $\mathbf{5 . 0}$ & 4.5 & 3.7 & 5.1 & 4.4 & 4.1 & 3.3 & 3.8 \\
\hline Domestic Bank & 1.6 & 1.6 & 1.6 & 2.0 & 3.4 & 2.7 & 3.8 & 1.1 & 2.4 \\
\hline External & 2.4 & 3.4 & 2.9 & 1.7 & 1.7 & 1.7 & 0.3 & 2.3 & 1.4 \\
\hline Disbursements & 2.4 & 3.4 & 2.9 & 1.7 & 1.7 & 1.7 & 0.3 & 2.2 & 1.3 \\
\hline Amortization & $\ldots$ & $\ldots$ & -3.2 & $\ldots$ & $\ldots$ & -0.3 & -2.0 & -0.2 & -1.0 \\
\hline Changes in arrears (-, reduction) & $\ldots$ & $\ldots$ & 3.2 & $\ldots$ & $\ldots$ & 0.3 & 1.8 & 0.0 & 0.8 \\
\hline Possible macroeconomic support & $\ldots$ & $\ldots$ & 0.0 & $\ldots$ & $\ldots$ & 0.0 & 0.3 & 0.3 & 0.3 \\
\hline
\end{tabular}

Sources: Data provided by the Georgian authorities; and staff estimates. 
Table 18. Georgia: Accounts of Extrabudgetary Funds, 1996-1997 1/

(In millions of lari)

\begin{tabular}{|c|c|c|c|c|}
\hline & \multicolumn{2}{|c|}{1996} & \multicolumn{2}{|c|}{1997} \\
\hline & Jan.-June & July-Nov. $2 /$ & Jan.-June & July-Dec. \\
\hline \multicolumn{5}{|l|}{ Social Security Fund } \\
\hline Revenue & 46.1 & 27.5 & 66.0 & 141.5 \\
\hline Payroll taxes & 26.3 & 15.8 & 39.8 & 98.0 \\
\hline Transfers from state budget & 16.5 & 9.5 & 20.2 & 35.5 \\
\hline For pensions & 13.9 & 9.5 & 16.1 & 19.1 \\
\hline For child allowances & 2.6 & $\ldots$ & ... & $\ldots$ \\
\hline Allowances households & $\ldots$ & $\ldots$ & 4.1 & 10.8 \\
\hline Electricity for pensioners & $\ldots$ & $\ldots$ & $\ldots$ & 5.6 \\
\hline Other & 3.3 & 1.5 & 6.0 & 8.0 \\
\hline Expenditure & 48.6 & 28.2 & 62.8 & 128.3 \\
\hline Pensions & 44.0 & 23.2 & 55.3 & 111.0 \\
\hline Child allowances & 2.8 & 2.2 & 0.3 & 0.3 \\
\hline Sickness allowances $3 /$ & 0.9 & 0.6 & 1.3 & 2.5 \\
\hline Allowances households & $\ldots$ & $\ldots$ & 4.1 & 3.7 \\
\hline Other & 0.9 & 2.3 & 1.8 & 10.8 \\
\hline Balance (-, deficit) & -2.5 & -0.6 & 3.2 & 13.2 \\
\hline \multicolumn{5}{|l|}{ Employment Fund } \\
\hline Revenue & 1.2 & 0.6 & 1.2 & 2.0 \\
\hline Expenditure & 0.6 & 0.6 & 1.4 & 1.6 \\
\hline Unemployment benefits & 0.1 & 0.1 & 0.8 & 0.7 \\
\hline Job programs & $\ldots$ & $\ldots$ & 0.2 & 0.3 \\
\hline Education and qualification & $\ldots$ & $\ldots$ & 0.3 & $\ldots$ \\
\hline Administration & 0.4 & 0.4 & 0.3 & 0.3 \\
\hline Balance (-, deficit) & 0.6 & 0.0 & -0.2 & 0.4 \\
\hline
\end{tabular}

Source: Georgian authorities.

1/ The Privatization Fund is not included because detailed data on this fund's activities are not available.

2/ For the Social Security Fund, the data relate to July-September, not July-November. For the Road Fund, the data relate to July-December.

$3 /$ Includes allowances for sickness, pregnancy and maternity. 
Table 18 (concluded). Georgia: Accounts of Extrabudgetary Funds, 1996-1997 1/ (In millions of lari)

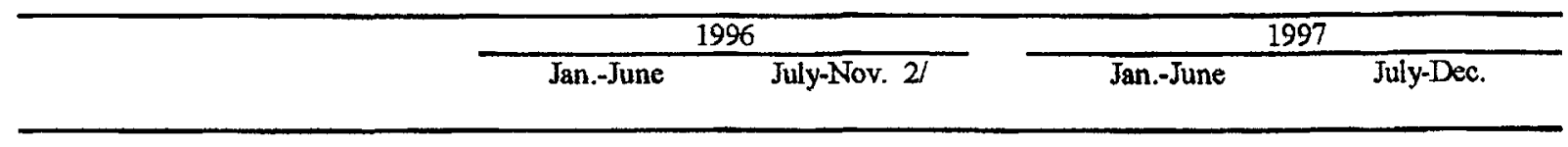

\section{Road Fund}

\begin{tabular}{|c|c|c|c|c|}
\hline Revenue & 6.9 & 12.7 & 12.9 & 21.7 \\
\hline Road user fees & 1.3 & 4.6 & 3.8 & 6.1 \\
\hline Oil tax & 0.3 & 0.3 & 0.3 & 0.7 \\
\hline Car tax & 1.5 & 4.5 & 1.6 & 3.7 \\
\hline Cross-border tax & 3.8 & 3.4 & 3.5 & 5.6 \\
\hline Advertisement tax & $\ldots$ & $\ldots$ & 0.1 & 0.1 \\
\hline Central budget allocations & $\ldots$ & $\ldots$ & 3.5 & 5.4 \\
\hline Expenditure & 8.0 & 11.6 & 16.5 & 20.9 \\
\hline Maintenance and repairs & 7.7 & 11.5 & 11.1 & 16.5 \\
\hline Construction & 0.3 & 0.1 & 0.4 & 4.4 \\
\hline Payment of arrears for 1996 & ... & 5.0 & 0.0 & .. \\
\hline $\begin{array}{l}\text { Balance (-, deficit) } \\
\text { of which: financed by }\end{array}$ & -1.1 & 1.1 & -3.6 & 0.8 \\
\hline arrears accumulation & -0.7 & $\cdots$ & $\cdots$ & ... \\
\hline
\end{tabular}

Source: Georgian authorities.

1/ The Privatization Fund is not included because detailed data on this fund's activities are not available. 2/ For the Social Security Fund, the data relate to July-September, not July-November. For the Road Fund, the data relate to July-December.

3/ Includes allowances for sickness, pregnancy and maternity. 
Table 19. Georgia: Marginal Rates of the Personal Income Tax

\begin{tabular}{|c|c|c|}
\hline \multicolumn{2}{|c|}{ Annual income } & \multirow[b]{2}{*}{ Marginal Rate } \\
\hline $1994-96$ & $1997-98$ & \\
\hline less than lari $10 \mathrm{H}$ & less than lari $200 \mathrm{I} /$ & 12 percent \\
\hline lari $10-20$ & lari $201-350$ & 15 percent \\
\hline lari $20-30$ & lari $351-600$ & 17 percent \\
\hline lari 30 and above & lari 601 and above & 20 percent \\
\hline
\end{tabular}

Source: Georgian authorities.

1/ A standard deduction of lari 3.5 per annum applied to all income taxpayers until June 1996, when it was raised to lari 108 per annum (lari 9 per month). 
Table 20. Georgia: Statutory Revenue Sharing Arrangements

\begin{tabular}{|c|c|c|c|c|c|c|}
\hline \multirow[b]{2}{*}{$\operatorname{Tax}$} & \multicolumn{2}{|c|}{ Up until Mar. 1, 1996} & \multicolumn{2}{|c|}{ Mar.-Dec. 1996} & \multicolumn{2}{|c|}{$1997-1998$} \\
\hline & $\begin{array}{l}\text { Percentage } \\
\text { Received by } \\
\text { State } \\
\text { Budget }\end{array}$ & $\begin{array}{l}\text { Percentage } \\
\text { Retained by } \\
\text { Local } \\
\text { Budget }\end{array}$ & $\begin{array}{c}\text { Percentage } \\
\text { Retained by } \\
\text { State } \\
\text { Budget }\end{array}$ & $\begin{array}{l}\text { Percentage } \\
\text { Retained by } \\
\text { Looal } \\
\text { Budget }\end{array}$ & $\begin{array}{c}\text { Percentage } \\
\text { Retained by } \\
\text { State } \\
\text { Budget }\end{array}$ & $\begin{array}{l}\text { Percentage } \\
\text { Retained by } \\
\text { Looal } \\
\text { Budget }\end{array}$ \\
\hline VAT $1 / 2 /$ & 90 & 10 & 70 & 30 & 100 & 0 \\
\hline Exoises & 100 & 0 & 100 & 0 & 100 & 0 \\
\hline Profit tax 3/ & 0 & 100 & 50 & 50 & 40 & 60 \\
\hline Inoome tax $3 /$ & 0 & 100 & 50 & 50 & 40 & 60 \\
\hline Customs duties $2 /$ & 70 & 30 & 100 & 0 & 100 & 0 \\
\hline Natural resource tax & 0 & 100 & 0 & 100 & 0 & 100 \\
\hline Ecology tax & 0 & 100 & 0 & 100 & 0 & 100 \\
\hline Land tax & 50 & 50 & so & 50 & 0 & 100 \\
\hline Property tax & 0 & 100 & 0 & 100 & 0 & 100 \\
\hline State duties & 0 & 100 & 0 & 100 & 0 & 100 \\
\hline Exchange bureau tax & 0 & 100 & 0 & 100 & 0 & 100 \\
\hline Fixed tax on oil imports 4 / & 0 & 100 & 0 & 100 & 0 & 100 \\
\hline
\end{tabular}

Source: Georgian authorities.

1/ Before 1996, 10 percent of VAT revenues was retained by most local governments, although some received a larger share. The sverage local government share in VAT revenues was around 25 pereent in 1995 and early 1996 . Effective March 1, 1996, the sharing rate for the city of Tbilisi is set at 35 percent, which was reduced to 13 percent effective January 1, 1998.

2/ For 1997, the region of Adjara retains 30 percent of VAT and 40 peroent of Customs duties.

3/ The city of Tbilisi keeps 55 percent of income tax and profit tax collections as from March 1, 1996.

4/ This tax was integrated with excise, VAT and customs duties, as from December 27, 1996. 
Table 21. Georgia: Number of Registered and Active Taxpayers, 1994-1998

\begin{tabular}{|c|c|c|c|c|c|c|c|}
\hline & \multicolumn{2}{|c|}{1995} & \multicolumn{2}{|c|}{1996} & \multicolumn{2}{|c|}{1997} & \multirow{2}{*}{$\frac{1998}{\text { January }}$} \\
\hline & January & July & Januaty & July & January & July & \\
\hline Registered taxpayers $1 /$ & 74,408 & 74,438 & 77,029 & 69,250 & 64,873 & 73,931 & 91,272 \\
\hline Active taxpayers $2 /$ & 30,123 & 35,500 & 39,870 & 42,600 & 53,086 & 31,989 & 48,754 \\
\hline Memorandum items: & & & & (In percent) & & & \\
\hline Increase in registered taxpayers $3 /$ & 0.7 & $\ldots$ & 3.5 & -10.1 & -6.3 & 14 & 23.5 \\
\hline Increase in active taxpayers $3 /$ & $-1: 4$ & 17.9 & 12.3 & 6.8 & 24.6 & -38.7 & 52.4 \\
\hline Active/registered taxpayers & 40.5 & 47.7 & 51.8 & 61.5 & 81.8 & 43.3 & 53.4 \\
\hline
\end{tabular}

Source: Georgian authorities.

$1 /$ Only enterprises are registered as taxpayers; in the case of wage earners paying personal income tax, the withholding enterprise is registered as the taxpayer.

2/ Active taxpayers are registered taxpayers who actually pay taxes.

3/ The increase for January 1995 is relative to October 1994, as data for earlier periods are not available. 


\begin{tabular}{lrrr} 
Spirits (except vodka/brandy) & 90 & 100 & 100 \\
Liquors & 60 & 100 & 100 \\
Ethyl alcohol & 0 & 0 & 100 \\
Vodka & 60 & 100 & 50 \\
Brandy & 75 & 100 & 50 \\
Champagne & 75 & 100 & 20 \\
Wine 2/ & 56 & 15 & 15 \\
Beer & 30 & 100 & 15 \\
Tobacco products 3/4/ & 40 & 100 & 100 \\
Passenger cars & 10 & 30 & 15 \\
Car tires & 5 & 50 & 15 \\
Gasoline 5/ & 10 & 15 & 15 \\
Jewelry & 20 & 50 & 35 \\
Carpets & 40 & 30 & 0 \\
Tea & 30 & 0 & 0 \\
Caviar, chocolate & 40 & 0 & 0 \\
Chewing Gum & 20 & 0 & 0 \\
China 6/ & 30 & 0 & 0 \\
Crystal glass & 40 & 0 & 0 \\
Leather products & 35 & 0 & 0 \\
Fur garments & 25 & 0 & 0 \\
& & & 0 \\
\hline Source: Georgin & & 0 & \\
\hline
\end{tabular}

Source: Georgian authorities.

1/ Prior to June 15, 1995, differential rates were applied to imports and domestically-produced goods. For imported goods, the shown rates were levied on a tax-exclusive basis; for domestically produced goods, the same rates were applied (except for beer at 10 percent), but on a tax-inclusive basis.

2/ As from December 27, 1996, wine not made from grapes is taxed at 50 percent, as are other fermented alcoholic beverages (e.g. cider).

3/ A lower rate ( 5 percent) applies to Class 3 and 4 cigarettes.

4/ A specific tax of 0.25 lari per pack for Class 1 and 2 cigarettes was introduced on October 1, 1997. For Class 3 and 4 cigarettes, the specific tax was 0.19 lari per pack.

5/ The excise tax on gasoline was increased to 60 percent on May 20, 1998.

6/ The excise tax on china was eliminated on January 30, 1995. 
Table 23. Georgis: Tax Arrears, $1995.97 \mathrm{l} /$

(Beginning of period)

\begin{tabular}{|c|c|c|c|c|c|c|}
\hline & \multicolumn{2}{|l|}{1995} & \multicolumn{2}{|c|}{1996} & \multicolumn{2}{|c|}{1997} \\
\hline & January & July & January & & January & July \\
\hline & \multicolumn{6}{|c|}{ (In millions of lari) } \\
\hline Total tax arrears $2 /$ & 14.8 & 30.5 & 68.1 & 121.7 & 129.7 & 169.4 \\
\hline VAT & 7.3 & 13.4 & 12.3 & 15.5 & 17.9 & 28.2 \\
\hline Profit tax & 4.9 & 10.6 & 13.6 & 9.2 & 7.9 & 5.4 \\
\hline Personal income tax & 0.0 & 0.1 & 0.2 & 0.8 & $\ldots$ & $\ldots$ \\
\hline Excise tax & 0.4 & 2.3 & 2.4 & 4.6 & 6.8 & 5.8 \\
\hline Property tax & 0.2 & 0.5 & 1.5 & 4.1 & $\ldots$ & $\ldots$ \\
\hline Land tax & $\ldots$ & $\ldots$ & 10.9 & 7.8 & 8.0 & 10.6 \\
\hline Other taxes collected by STS & 1.9 & 3.6 & 4.6 & 7.7 & 9.5 & 12.6 \\
\hline Taxes collected by Customs & $\ldots$ & $\ldots$ & $\ldots$ & 1.6 & 1.7 & 3.2 \\
\hline Payroll taxes & $\ldots$ & $\ldots$ & 22.8 & 39.2 & 49.2 & 62.4 \\
\hline Pension Fund & $\cdots$ & $\ldots$ & 22.8 & 38.4 & 49.2 & 62.4 \\
\hline \multirow[t]{2}{*}{ Employment Fund } & $\ldots$ & $\ldots$ & $\cdots$ & 0.8 & $\ldots$ & $\ldots$ \\
\hline & \multicolumn{6}{|c|}{ (In percent of GDP) 3 / } \\
\hline Total tax arrears $2 /$ & 1.1 & 1.1 & 1.8 & 2.1 & 2.3 & 2.5 \\
\hline VAT & 0.5 & 0.5 & 0.3 & 0.5 & 0.5 & 0.6 \\
\hline Profit tax & 0.4 & 0.4 & 0.4 & 0.3 & 0.3 & 0.3 \\
\hline Personal income tax & $\ldots$ & $\ldots$ & $\ldots$ & $\ldots$ & $\ldots$ & $\ldots$ \\
\hline Excise tax & $\ldots$ & 0.1 & 0.1 & 0.1 & 0.1 & 0.2 \\
\hline Property tax & $\ldots$ & $\ldots$ & $\ldots$ & 0.1 & $\ldots$ & $\ldots$ \\
\hline Land tax & $\ldots$ & $\ldots$ & 0.3 & 0.2 & 0.1 & 0.2 \\
\hline Other taxes collected by STS & 0.1 & 0.1 & 0.1 & 0.2 & 0.3 & 0.3 \\
\hline Taxes collected by Customs & $\ldots$ & $\ldots$ & $\ldots$ & $\ldots$ & $\ldots$ & $\ldots$ \\
\hline Payroll taxes & $\ldots$ & $\ldots$ & 0.6 & 0.7 & 0.9 & 0.9 \\
\hline Pension Fund & $\ldots$ & $\ldots$ & 0.6 & 0.7 & 0.9 & 0.9 \\
\hline Employment Fund & $\ldots$ & $\ldots$ & $\ldots$ & $\ldots$ & $\ldots$ & $\ldots$ \\
\hline
\end{tabular}

Sources: Georgian authorities; and staff estimates.

1/ The coverage of tax arrears is more complete for 1996, since arrears in contributions to the Pension Fund are included. Also, as from December 1, 1996 the data include arrears of taxes collected by the State Customs Department and payroll taxes collected by Employment Fund. Arrears to the Health Fund, the Road Fund, and some local governments taxes are excluded. 2/ The data include unpaid penalties for overdue tax payment obligations, hiding income.

3/ Presented as a percentage of GDP in the preceding four quarters. 
Table 24. Georgia: Public Expenditure in Education and Health 1/

\begin{tabular}{|c|c|c|c|}
\hline & 1996 & 1997 & $19982 /$ \\
\hline & \multicolumn{2}{|c|}{ (In millions of lari) } & \\
\hline Education expenditure & 68.5 & 120.0 & 135.0 \\
\hline Central government & 21.2 & 55.2 & 48.0 \\
\hline Local governments & 47.3 & 64.8 & 87.0 \\
\hline Health expenditure & 40.3 & 70.8 & 95.0 \\
\hline Central government 3 / & 25.0 & 50.6 & 75.0 \\
\hline \multirow[t]{2}{*}{ Local governments } & 15.3 & 20.2 & 20.0 \\
\hline & \multicolumn{2}{|c|}{ (In percent of GDP) } & \\
\hline \multicolumn{4}{|l|}{ Memorandum items: } \\
\hline Education expenditure & 1.2 & 1.8 & 1.7 \\
\hline Health expenditure & 0.7 & 1.0 & 1.2 \\
\hline
\end{tabular}

Source: Georgian authorities.

1/ Includes central government, local governments, and Social Security system.

2/ Projected (1998 budget).

3/ Includes Social Security expenditures. 
Table 25. Georgia: 1998 State Budget

\begin{tabular}{|c|c|c|}
\hline & $\begin{array}{c}\text { In m illions } \\
\text { of lari }\end{array}$ & $\begin{array}{l}\text { In percent } \\
\text { of GDP }\end{array}$ \\
\hline Total Revenues and Grants & 726.2 & 9.0 \\
\hline Total Revenue & 692.2 & 8.6 \\
\hline Tax sevenue (excluding extrabudgetary) & 476.9 & 5.9 \\
\hline Taxos on incom & 36.6 & 0.5 \\
\hline Taxes on profits & 19.9 & 0.2 \\
\hline V A T & 253.4 & 3.1 \\
\hline Domestic & 162 & 2.0 \\
\hline Im ports & 91.4 & 1.1 \\
\hline Custom duties & 59 & 0.7 \\
\hline Other taxes & 108 & 1.3 \\
\hline Cigarettes & $\ldots$ & 0.0 \\
\hline Other excises & 108 & 1.3 \\
\hline Local taxes & 0 & 0.0 \\
\hline Land tax & 0 & 0.0 \\
\hline Property tax & 0 & 0.0 \\
\hline $\mathrm{Natural}$ resources & 0 & 0.0 \\
\hline Environm en $t$ & 0 & 0.0 \\
\hline Other & 0 & 0.0 \\
\hline Nontax revenue & 58 & 0.7 \\
\hline of which: NBG profits & $\boldsymbol{\tau}$ & 0.1 \\
\hline Revenue from net lending & 16 & 0.2 \\
\hline Fees/budgetary organizations & 20 & 0.2 \\
\hline Other revenue & 15 & 0.2 \\
\hline Extrabudgetary revenue & 157.3 & 1.9 \\
\hline$S S F$ and $E F$ & 117.3 & 1.5 \\
\hline Road Fund & 25 & 0.3 \\
\hline Privatization & 15 & 0.2 \\
\hline Grants & 34 & 0.4 \\
\hline Total expenditure and net lending & 938.8 & 11.6 \\
\hline Total expenditure & 895.8 & 11.1 \\
\hline Current expenditure & 839.9 & 10.4 \\
\hline Wages and salaries & 104.3 & 1.3 \\
\hline Travel & 6.3 & 0.1 \\
\hline Other goods and services & 282.7 & 3.5 \\
\hline o/w Food for the m ilitary & $\ldots$ & 0.0 \\
\hline Other & $\ldots$ & 0.0 \\
\hline Subsidies and other current transfers & 358.1 & 4.4 \\
\hline Interest payments & 88.5 & 1.1 \\
\hline Dom estic & 45 & 0.6 \\
\hline External & 49.8 & 0.6 \\
\hline Rescheduled debt & 46.9 & 0.6 \\
\hline Nonrescheduled debt & 2.9 & 0.0 \\
\hline o/w post1994 & $\ldots$ & 0.0 \\
\hline Other current expenditures & $6 . \ddot{2}$ & 0.1 \\
\hline o/w Health & $\ldots$ & 0.0 \\
\hline O ther & $\ldots$ & 0.0 \\
\hline Unclassified expenditure & $\ldots$ & 0.0 \\
\hline Extrabudgetary expenditures & $\ldots$ & 0.0 \\
\hline Local government expenditures & $\ldots$ & 0.0 \\
\hline Capital expenditure & 55.9 & 0.7 \\
\hline Net lending & 43 & 0.5 \\
\hline Deficit (com m itments) & -212.6 & -2.6 \\
\hline \multicolumn{3}{|l|}{ Memorandum Items } \\
\hline GDP (estimate, in millions of lari) & 8,070 & $\ldots$ \\
\hline Revenue and expenditure of local governments & 235 & 2.9 \\
\hline Number of employees $1 /$ & 157,566 & $\ldots$ \\
\hline
\end{tabular}

Source: Georgian authorities.

1/ Excludes local government em ployees. 
Table 26. Georgia: Monetary Survey 1/

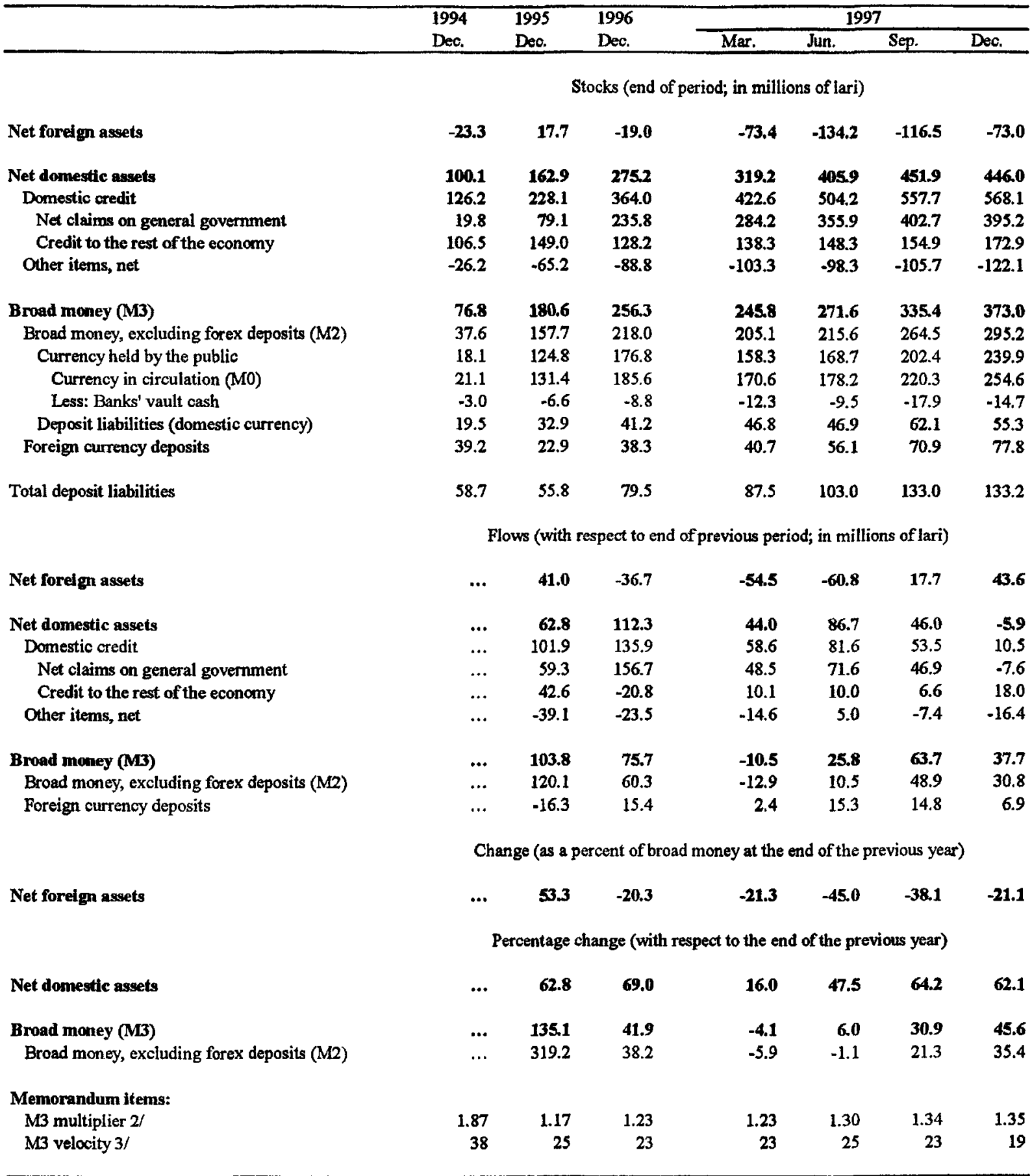

Source: National Bank of Georgia; and Fund staff estimates.

1/ Valued at end-period actual exchange rates.

2/ $\mathrm{M} 3$ divided by reserve money.

3/ Annualized quarterly GDP divided by end-quarter M3. 
Table 27. Georgia: Accounts of the National Bank of Georgia 1/

\begin{tabular}{|c|c|c|c|c|c|c|c|}
\hline & \multirow{2}{*}{$\begin{array}{l}1994 \\
\text { Dec. }\end{array}$} & \multirow{2}{*}{$\begin{array}{l}1995 \\
\text { Dec. }\end{array}$} & \multirow{2}{*}{$\begin{array}{l}1996 \\
\text { Dec. }\end{array}$} & \multicolumn{4}{|c|}{1997} \\
\hline & & & & Mar. & Jun. & Sep. & Dec. \\
\hline & \multicolumn{7}{|c|}{ Stocks (end of period; in millions of lari) } \\
\hline Net international reserves & 3.3 & 57.1 & -41.0 & -99.2 & -160.1 & -153.7 & -106.0 \\
\hline Gold & 1.5 & 1.5 & 1.5 & 0.9 & 0.9 & 0.8 & 0.7 \\
\hline Foreign exchange reserves & 53.7 & 197.7 & 201.5 & 139.0 & 130.1 & 131.3 & 225.9 \\
\hline Use of Fund Resources & -51.9 & -142.1 & -244.0 & -239.0 & -290.4 & -285.2 & -332.0 \\
\hline Other foreign assets, net & -0.1 & -0.1 & -0.1 & -0.1 & -0.6 & -0.6 & -0.6 \\
\hline Net donestic assets & 37.7 & 96.7 & 250.0 & 299.5 & 368.3 & 403.6 & 383.0 \\
\hline Net claims on general government & 27.7 & 94.6 & 249.0 & 302.8 & 366.7 & 412.4 & 398.1 \\
\hline Claims on banks & 3.9 & 4.2 & 13.7 & 10.6 & 5.3 & 4.4 & 3.5 \\
\hline Other items, net & 6.1 & -2.1 & -12.7 & -13.8 & -3.8 & -13.2 & -18.5 \\
\hline Reserve money & 41.0 & 153.8 & 209.0 & 200.3 & 208.2 & 249.9 & 277.1 \\
\hline Currency in circulation & 21.1 & 131.4 & 185.6 & 170.6 & 178.2 & 220.3 & 254.6 \\
\hline Required reserves & 7.9 & 11.9 & 13.7 & 12.7 & 14.3 & 15.2 & 15.7 \\
\hline \multirow[t]{2}{*}{ Balances on banks' correspondent a/cs } & 12.0 & 10.5 & 9.7 & 17.0 & 15.7 & 14.4 & 6.9 \\
\hline & \multicolumn{7}{|c|}{ Flows (with respect to end of previous period; in millions of lari) } \\
\hline Net international reserves & $\cdots$ & $\mathbf{5 3 . 7}$ & -98.1 & -58.2 & -60.9 & 6.4 & 47.7 \\
\hline Net domestic assets & ... & 59.0 & 153.2 & 49.5 & 68.8 & 35.3 & -20.5 \\
\hline Net claims on general government & $\ldots$ & 66.9 & 154.4 & 53.8 & 64.0 & 45.7 & -14.3 \\
\hline Claims on banks & $\ldots$ & 0.3 & 9.5 & -3.2 & -5.3 & -0.9 & -0.9 \\
\hline Other items, net & $\cdots$ & -8.2 & -10.7 & -1.1 & 10.1 & -9.5 & -5.3 \\
\hline Reserve money & $\ldots$ & 112.8 & 55.2 & -8.7 & 7.9 & 41.7 & 27.2 \\
\hline Currency in circulation & $\ldots$ & 110.3 & 54.2 & -15.0 & 7.6 & 42.1 & 34.2 \\
\hline Required reserves & $\cdots$ & 4.0 & 1.8 & -1.0 & 1.6 & 0.9 & 0.5 \\
\hline \multirow[t]{2}{*}{ Balances on banks' correspondent a/cs } & $\cdots$ & -1.5 & -0.8 & 7.3 & -1.3 & -1.3 & -7.5 \\
\hline & \multicolumn{7}{|c|}{ Change (as a percent of reserve money last year) } \\
\hline \multirow[t]{2}{*}{ Net international reserves } & $\cdots$ & 131.0 & -63.8 & -27.9 & -57.0 & -53.9 & $-\mathbf{3 1 . 1}$ \\
\hline & \multicolumn{7}{|c|}{ Percentage change (with respect to the end of the previous year) } \\
\hline Net domestic assets & ... & 156.5 & 158.4 & 19.8 & 47.3 & 61.4 & $\mathbf{5 3 . 2}$ \\
\hline Reserve money & ... & 274.9 & 35.9 & -4.2 & -0.4 & 19.6 & 32.6 \\
\hline Currency in circulation & $\ldots$ & 522.6 & 41.2 & -8.1 & -4.0 & 18.7 & 37.2 \\
\hline
\end{tabular}

Sources: National Bank of Georgia; and Fund staff estimates.

1/ Valued at end-period actual exchange rates. 
Table 28. Georgia: Summary Accounts of Commercial Banks 1/ (In millions of lari)

\begin{tabular}{|c|c|c|c|c|c|c|c|}
\hline & \multirow{2}{*}{$\begin{array}{l}1994 \\
\text { Dec. }\end{array}$} & \multirow{2}{*}{$\begin{array}{l}1995 \\
\text { Dec. }\end{array}$} & \multirow{2}{*}{$\begin{array}{l}1996 \\
\text { Dec. }\end{array}$} & \multicolumn{4}{|c|}{1997} \\
\hline & & & & Mar. & Jun. & Sep. & Dec. \\
\hline Net foreign assets & -26.6 & -39.3 & 22.1 & 25.8 & 25.9 & 37.1 & 33.0 \\
\hline NFA convertible & -26.7 & -39.2 & 22.0 & 25.6 & 25.3 & 36.7 & 32.7 \\
\hline Gold & 0.3 & 0.4 & 0.2 & 0.8 & 0.8 & 0.8 & 1.1 \\
\hline Foreign exchange & 33.1 & 21.1 & 27.9 & 34.9 & 42.0 & 55.5 & 47.2 \\
\hline Foreign liabilities & -60.1 & -60.8 & -6.1 & -10.1 & -17.5 & -19.7 & -15.6 \\
\hline NFA nonconvertible & 0.1 & -0.1 & 0.1 & 0.2 & 0.6 & 0.5 & 0.3 \\
\hline Net domestic assets & 85.3 & 95.1 & 57.5 & 61.7 & 77.1 & 95.8 & 100.2 \\
\hline Domestic credit & 98.5 & 133.5 & 115.0 & 119.8 & 137.4 & 145.3 & 170.0 \\
\hline Net claims on general government & -7.9 & -15.5 & -13.2 & -18.5 & -10.9 & -9.7 & -2.9 \\
\hline Net claims on republican government & -3.1 & -7.3 & -6.7 & -10.2 & -5.6 & -4.6 & 0.4 \\
\hline Claims on private sector & 106.5 & 149.0 & 128.2 & 138.3 & 148.3 & 154.9 & 172.9 \\
\hline of which: foreign exchange loans & 0.0 & 63.7 & 45.0 & 46.9 & 53.8 & 68.9 & 77.0 \\
\hline Other assets (net) & -13.2 & -38.4 & -57.5 & -58.1 & -60.4 & -49.4 & -69.9 \\
\hline Deposit liabillties & 58.7 & 55.8 & 79.5 & 87.5 & 103.0 & 133.0 & 133.2 \\
\hline Domestic currency deposits & 19.5 & 32.9 & 41.2 & 46.8 & 46.9 & 62.1 & 55.3 \\
\hline Foreign currency deposits & 39.2 & 22.9 & 38.3 & 40.7 & 56.1 & 70.9 & 77.8 \\
\hline \multicolumn{8}{|l|}{ Memorandum items: } \\
\hline Share of foreign exchange deposits & 66.8 & 41.1 & 48.2 & 46.6 & 54.5 & 53.3 & 58.4 \\
\hline Exchange rate (in lari, end-period) & 1.280 & 1.230 & 1.274 & 1.294 & 1.300 & 1.298 & 1.304 \\
\hline
\end{tabular}

Source: National Bank of Georgia; and Fund staff estimates.

1/ Valued at end-period actual exchange rates. 


\begin{tabular}{|c|c|c|c|c|c|c|c|c|c|c|}
\hline & \multirow{2}{*}{$\begin{array}{l}1994 \\
\text { Dec. }\end{array}$} & \multirow{2}{*}{$\begin{array}{l}1995 \\
\text { Dec. }\end{array}$} & \multicolumn{4}{|c|}{1996} & \multicolumn{4}{|c|}{1997} \\
\hline & & & Mar. & Jun. & Sep. & Dec. & Mar. & Jun. & Sep. & Dec. \\
\hline & \multicolumn{10}{|c|}{ (In millions of lari, end of period) } \\
\hline Domestic currency deposits & 19.5 & 32.9 & 30.5 & 45.7 & 44.4 & 41.2 & 46.8 & 46.9 & 62.1 & 55.3 \\
\hline Deposits of enterprises $1 /$ & 16.7 & 27.9 & 25.2 & 39.8 & 38.2 & 34.3 & 39.5 & 39.1 & 52.1 & 45.0 \\
\hline Deposits of households/individuals & 2.8 & 5.0 & 5.3 & 5.9 & 6.2 & 7.0 & 7.3 & 7.8 & 10.0 & 10.3 \\
\hline Foreign currency deposits & 39.2 & 22.9 & 39.0 & 30.3 & 34.7 & 38.3 & 40.7 & 56.1 & 70.9 & $\mathbf{7 7 . 8}$ \\
\hline Deposits of enterprises $1 /$ & $\ldots$ & 17.6 & 33.7 & 20.3 & 24.2 & 25.3 & 25.0 & 35.0 & 41.3 & 44.0 \\
\hline Deposits of households/individuals & $\cdots$ & 5.3 & 5.3 & 10.0 & 10.5 & 13.0 & 15.7 & 21.1 & 29.6 & 33.8 \\
\hline Total deposits & 58.8 & 55.8 & 69.5 & 76.0 & 79.1 & 79.5 & 87.5 & 103.0 & 133.0 & 133.2 \\
\hline Deposits of enterprises $1 /$ & $\ldots$ & 45.5 & 58.9 & 60.1 & 62.4 & 59.6 & 64.5 & 74.1 & 93.4 & 89.0 \\
\hline \multirow[t]{2}{*}{ Deposits of households/individuals } & $\cdots$ & 10.3 & 10.6 & 15.9 & 16.7 & 20.0 & 23.0 & 28.9 & 39.6 & 44.1 \\
\hline & \multicolumn{10}{|c|}{ (Percent of total) } \\
\hline Domestic currency deposits & 33.2 & 59.0 & 43.9 & 60.1 & 56.1 & 51.8 & 53.5 & 45.5 & 46.7 & 41.5 \\
\hline Deposits of enterprises $1 /$ & 28.4 & 50.0 & 36.3 & 52.4 & 48.3 & 43.1 & 45.1 & 38.0 & 39.2 & 33.8 \\
\hline Deposits of households/individuals & 4.8 & 9.0 & 7.6 & 7.8 & 7.8 & 8.7 & 8.3 & 7.6 & 7.5 & 7.7 \\
\hline Foreign currency deposits & 66.7 & 41.0 & 56.1 & 39.9 & 43.9 & 48.2 & 46.5 & 54.5 & 53.3 & 58.5 \\
\hline Deposits of enterprises $1 /$ & $\ldots$ & 31.5 & 48.5 & 26.7 & 30.6 & 31.8 & 28.6 & 34.0 & 31.1 & 33.1 \\
\hline Deposits of households/individuals & $\cdots$ & 9.5 & 7.6 & 13.2 & 13.3 & 16.4 & 17.9 & 20.5 & 22.3 & 25.4 \\
\hline Total deposits & 100.0 & 100.0 & 100.0 & 100.0 & 100.0 & 100.0 & 100.0 & 100.0 & 100.0 & 100.0 \\
\hline Deposits of enterprises $1 /$ & $\ldots$ & 81.5 & 84.7 & 79.1 & 78.9 & 74.9 & 73.7 & 71.9 & 70.2 & 66.9 \\
\hline Deposits of households/individuals & $\cdots$ & 18.5 & 15.3 & 20.9 & 21.1 & 25.1 & 26.3 & 28.1 & 29.8 & 33.1 \\
\hline \multicolumn{11}{|l|}{ Memorandum items: } \\
\hline \multicolumn{11}{|l|}{ Foreign currency deposits } \\
\hline (In US\$ millions) $2 i$ & 30.6 & 18.6 & 30.9 & 24.2 & 27.3 & 30.1 & 31.5 & 43.2 & 54.6 & 59.7 \\
\hline Exchange rate (lari/US\$;end-period) & 1.280 & 1.230 & 1.262 & 1.254 & 1.270 & 1.274 & 1.294 & 1.300 & 1.298 & 1.304 \\
\hline
\end{tabular}

Sources: National Bank of Georgia; and staff estimates.

1/ Including deposits of cooperatives, state companies, and so-called public organizations.

2/ Reported data in domestic currency, converted at end-period exchange rate. 
Table 30. Georgia: Currency Composition of Commercial Bank Credit 1/

\begin{tabular}{|c|c|c|c|c|c|c|c|c|c|c|}
\hline & \multirow{2}{*}{$\begin{array}{l}1994 \\
\text { Dec }\end{array}$} & \multirow{2}{*}{$\begin{array}{l}1995 \\
\text { Dec }\end{array}$} & \multicolumn{4}{|c|}{1996} & \multicolumn{4}{|c|}{1997} \\
\hline & & & Mar. & Jun. & Sep. & Dec. & Mar. & Jun. & Sep. & Dec. \\
\hline & \multicolumn{10}{|c|}{ (In millions of lari) } \\
\hline Credit to the economy $2 /$ & 102.9 & 149.0 & 168.3 & 126.5 & 109.1 & 128.2 & 138.3 & 148.3 & 154.9 & 172.9 \\
\hline Domestic currency claims & 37 & 62.7 & 78.6 & 88.2 & 71.6 & 83.2 & 91.4 & 94.5 & 86.0 & 95.9 \\
\hline Foreign currency claims & 65.9 & 86.2 & 89.6 & 38.2 & 37.6 & 45.0 & 46.9 & $\$ 3.8$ & 68.9 & 77.0 \\
\hline Onlending of Turkish credit 3 / & 53.1 & 54.6 & 57.9 & 0.0 & 0.0 & 0.0 & 0.0 & 0.0 & 0.0 & 0.0 \\
\hline \multirow[t]{2}{*}{ Other foreign currency claims } & 12.7 & 31.7 & 31.6 & 38.2 & 37.6 & 45.0 & 46.9 & 53.8 & 68.9 & 77.0 \\
\hline & \multicolumn{10}{|c|}{ (In percent of total) } \\
\hline Credit to the economy $2 /$ & 100 & 100.0 & 100.0 & 100.0 & 100.0 & 100.0 & 100.0 & 100.0 & 100.0 & 100.0 \\
\hline Domestic currency claims & 35.9 & 42.1 & 46.7 & 69.7 & 65.6 & 64.9 & 66.1 & 63.7 & 55.5 & 55.5 \\
\hline Foreign currêncy claims & 64.1 & 57.9 & 53.3 & 30.3 & 34.5 & 35.1 & 33.9 & 36.3 & 44.5 & 44.5 \\
\hline Onlending of Turkish credit 3 / & 51.6 & 36.6 & 34.4 & 0.0 & 0.0 & 0.0 & 0.0 & 0.0 & 0.0 & 0.0 \\
\hline Other foreign currency claims & 12.4 & 21.3 & 18.8 & 30.3 & 34.5 & 35.1 & 33.9 & 36.3 & 44.5 & 44.5 \\
\hline \multicolumn{11}{|l|}{ Memorandum items: } \\
\hline Exchange rate (lari/US\$; end-period) & 1.280 & 1.230 & 1.262 & 1.254 & 1.270 & 1.274 & 1.294 & 1.300 & 1.298 & 1.304 \\
\hline
\end{tabular}

Sources: National Bank of Georgia; and staff estimates.

1/ Excluding claims of the Savings Bank before July 1995.

2/ Credit to the nongovernment sectors.

3/ The government of Turkey, through Eximbank (Turkey) extended a credit line in the amount of US\$50 million to Georgia in 1993. The loan was administered by

Eximbank (Georgia) and guaranteed by the Government; the Government determined who received the loans. In May 1996, the Government assumed

responsibility for this credit and carved it out of the balance sheet of the United Georgian Bank. 
Table 31. Georgia: Regulatory Framework for Commercial Banks

\begin{tabular}{|c|c|c|}
\hline Type & Prudential Regulation & Recommended BIS Standards $1 /$ \\
\hline \multicolumn{3}{|l|}{ Compulsory Standards } \\
\hline \multicolumn{3}{|l|}{ Capital Adequacy Ratios } \\
\hline Tier One Capital $2 /$ & $\begin{array}{l}8 \text { percent (not risk-weighted) of total } \\
\text { assets, and at least } 75 \text { percent of total } \\
\text { capital 3/ }\end{array}$ & $\begin{array}{l}4 \text { percent (risk weighted) of total assets, } \\
\text { and at least } 50 \text { percent of total capital }\end{array}$ \\
\hline Total Capital 4! & 10 percent (not risk-weighted) $3 f$ & 8 percent (risk weighted) \\
\hline Liquidity Indicator & $\begin{array}{l}\text { Maintain liquid assets above } 30 \text { percent } \\
\text { of total liabilities }\end{array}$ & No liquidity indicator \\
\hline \multicolumn{3}{|l|}{ Limits on Lending } \\
\hline Lending to a single insider & 5 percent of total capital & No specific limit \\
\hline Total lending to insiders & 50 percent of total capital $5 /$ & 20 percent of total funds \\
\hline Lending to a single outsider & 15 percent of total capitsl & 25 percent of total capital \\
\hline Total lending to the 10 largest debtors & 50 percent of total loans & No specific limit \\
\hline Limits on Total Deposit Liabilities & Ratio of $9: 1$ relative to total capital & No recommended limits \\
\hline Loan Loss Provisioning Requirements & $\begin{array}{l}2 \text { percent for performing loans } \\
5-10 \text { percent for watch loans } \\
30-40 \text { percent for sub-standard loans } \\
50-70 \text { percent for doubtful loans } \\
100 \text { percent for loss loans }\end{array}$ & $\begin{array}{l}\text { No recommended standards, but } \\
\text { Georgian requirements are more } \\
\text { strict than most individual BIS member } \\
\text { countries }\end{array}$ \\
\hline \multicolumn{3}{|l|}{ Minimum Capital Licensing Requirements } \\
\hline $\begin{array}{l}\text { For New Banks } \\
\text { For Licensed Banks }\end{array}$ & $\begin{array}{l}\text { Lari } 5 \text { million } \\
\text { December } 31,1997 \text {-- US\$0.25 million } \\
\text { June 30, } 1998 \text {-- US\$0.5 million } \\
\text { December 31, } 1998 \text { - lari } 1 \text { million } \\
\text { June } 30,1999 \text {-- lari } 2 \text { million } \\
\text { December 31, } 1999 \text {-- lari } 3 \text { million } \\
\text { June 30, 2000 -- lari } 4 \text { million } \\
\text { December 31, 2000 -- lari } 5 \text { million }\end{array}$ & $\begin{array}{l}\text { ECU } 5 \text { million } 6 / \\
\text { ECU } 5 \text { milition } 6 /\end{array}$ \\
\hline \multicolumn{3}{|l|}{ Recommended Guidelines } \\
\hline Limit on Fixed Assets & $\begin{array}{l}\text { Keep fixed assels less than } 20 \\
\text { percent of primary capital plus total } \\
\text { liabilities }\end{array}$ & No recommended limits \\
\hline Limit on Long-term Assets & $\begin{array}{l}\text { Keep long-term assets equal to } 100 \\
\text { percent of long-term liabilities }\end{array}$ & No recommended limits \\
\hline Limit on Current Assets & $\begin{array}{l}\text { Keep current assets equal to } 100 \\
\text { percent of current liabilities }\end{array}$ & No recommended limits \\
\hline \multicolumn{3}{|l|}{ Other Requirements } \\
\hline Limit on Ownership by Anyone Founder & 25 percent & No recommended limits \\
\hline Financial Statements and Ratio Calculations & Monthly & $\begin{array}{l}\text { No recommended standards, but most } \\
\text { BIS member countries require quarterly } \\
\text { reporting }\end{array}$ \\
\hline Annual Audits & $\begin{array}{l}\text { To be performed by a recognized } \\
\text { auditing firm and certified accountants }\end{array}$ & $\begin{array}{l}\text { External audits encouraged, to complement } \\
\text { internal auditing }\end{array}$ \\
\hline
\end{tabular}

Source: National Bank of Georgia; and Fund staff.

1/ BIS (Bank for International Settlements) recommended standards, which were adopted in September 1997, are the minimum requirements. $2 /$ "Tier One Capital" includes (i) share capital; (ii) capital reserves; (iii) retained profits; (iv) foreign exchange valuation changes on shares purchased in foreign currency; (v) less any revaluation of fixed assets; (vi) less any treasury stock.

3/ Regulations on the classification of assets by the underlying risk involved will be announced in June 1998 and will become effective by January 1, 1999.

4/ "Total Capital" includes Tier One Capital plus (i) appropriated reserves; (ii) revaluation of fixed assets according to a prespecified schedule; (iii) any loan loss provisioning for performing loans.

S/ Limit on total insider lending will be lowered to is percent of paid-in capital effective January 1, 1999.

6/ Represents the minimum capital standard adopted by EU member ccuntries; no BIS recommended limits available on minimum capital. 
Table 32. Georgia: Interest rates, 1995-97

(In percent per annum, non-compounded)

\begin{tabular}{|c|c|c|c|c|c|c|c|c|c|c|c|c|}
\hline & Mar-95 & Jun-95 & Sep-95 & Dec-95 & Mar-96 & Jun-96 & Sep-96 & Dec-96 & Mar-97 & Jun-97 & Sep-97 & Dec-97 \\
\hline \multicolumn{13}{|c|}{ Commercial banks (3 month) $1 /$} \\
\hline Deposits & 37.2 & 27.4 & 17.6 & 17.9 & 17.3 & 14.8 & 14.8 & 16.1 & 13.5 & 13.2 & 15.4 & 12.6 \\
\hline Domestic currency & 49.3 & 33.7 & 20.1 & 15.0 & 17.1 & 13.4 & 11.8 & 14.3 & 11.7 & 10.3 & 12.2 & 10.6 \\
\hline Former state banks & 52.3 & 33.3 & 20.7 & 19.0 & 19.7 & 9.3 & 7.7 & 13.0 & 10.7 & 7.0 & 9.7 & 9.0 \\
\hline Other & 47.0 & 34.0 & 19.8 & 12.0 & 15.3 & 18.0 & 16.0 & 15.3 & 12.7 & 13.7 & 14.7 & 13.0 \\
\hline Foreign currency & 25.2 & 21.0 & 15.1 & 20.8 & 17.4 & 16.1 & 17.7 & 17.9 & 15.4 & 16.1 & 18.7 & 14.5 \\
\hline Former state banks & 32.7 & 26.7 & 25.0 & 26.0 & 16.7 & 13.7 & 23.0 & 22.0 & 18.3 & 16.7 & 20.7 & 10.0 \\
\hline Other & 14.0 & 12.5 & 10.2 & 17.6 & 17.8 & 17.3 & 15.0 & 15.8 & 13.6 & 15.8 & 17.3 & 19.0 \\
\hline Loans & 111.2 & 94.1 & 79.2 & 69.8 & 75.5 & 60.6 & 62.3 & 53.2 & 62.6 & 55.6 & 43.9 & 45.0 \\
\hline Domestic currency & 115.0 & 92.0 & 77.9 & 66.1 & 72.7 & 60.6 & 58.9 & 51.3 & 64.4 & 58.4 & 43.4 & 48.5 \\
\hline Former state banks & 154.7 & 104.3 & 79.7 & 68.7 & 75.0 & 66.7 & 62.7 & 49.0 & 65.7 & 65.7 & 46.3 & 55.5 \\
\hline Other & 85.3 & 82.8 & 76.5 & 64.3 & 71.0 & 56.0 & 56.0 & 52.5 & 63.5 & 53.0 & 41.3 & 41.5 \\
\hline Foreign currency & 107.4 & 96.2 & 80.6 & 73.4 & 78.2 & 60.6 & 65.8 & 55.0 & 60.8 & 52.8 & 44.4 & 41.5 \\
\hline Former state banks & 116.3 & 107.3 & 91.0 & 90.0 & 87.0 & 69.0 & 67.3 & 61.5 & 64.3 & 54.0 & 47.0 & 44.0 \\
\hline Other & 94.0 & 79.5 & 65.0 & 48.5 & 65.0 & 48.0 & 63.5 & 48.5 & 55.5 & 51.0 & 40.5 & 39.0 \\
\hline \multicolumn{13}{|l|}{ Interbank credit auction } \\
\hline 7 days & $\cdots$ & 65.5 & 42.7 & 36.5 & 44.0 & 30.0 & 14.3 & 13.0 & 16.0 & $\ldots$ & 14.0 & 31.0 \\
\hline 1 month & $\cdots$ & ... & $\ldots$ & $\ldots$ & 48.7 & 41.0 & 35.5 & 27.3 & 19.0 & 21.0 & 30.0 & 46.0 \\
\hline 2 month & $\ldots$ & $\ldots$ & $\cdots$ & $\ldots$ & $\ldots$ & $\ldots$ & 38.0 & $\ldots$ & $\ldots$ & $\ldots$ & $\ldots$ & 32.0 \\
\hline 3 month & $\cdots$ & $\cdots$ & $\cdots$ & $\cdots$ & 70.0 & 46.0 & 40.0 & 36.3 & 19.0 & $\cdots$ & 32.0 & ... \\
\hline \multicolumn{13}{|l|}{ Memorandum items: } \\
\hline $\begin{array}{l}\text { 12-month inflation } \\
\text { Interest rate spread } 2 /\end{array}$ & 1233.7 & 448.5 & 5.3 & 57.4 & 55.0 & 54.9 & 42.2 & 14.2 & 8.5 & 5.1 & 5.7 & 7.1 \\
\hline In domestic currency & 65.7 & 58.3 & 57.7 & 51.1 & 55.6 & 47.1 & 47.0 & 37.0 & 52.8 & 48.1 & 31.3 & 37.9 \\
\hline In foreign currency & 82.2 & 75.2 & 65.5 & 52.7 & 60.8 & 44.5 & 48.1 & 37.1 & 45.4 & 36.7 & 25.7 & 27.0 \\
\hline
\end{tabular}

Source: National Bank of Georgia.

1/ Because of missing values, the sample of banks included varies by instrument, therefore comparisons across instruments should be interpreted with caution. Banks are weighted equally through [...] 1997 and by value after wards, as are foreign currency and domestic instruments.

$2 /$ Defined as lending rate minus deposit rate. 


\begin{tabular}{|c|c|c|c|c|c|}
\hline & 1993 & 1994 & 1995 & $\begin{array}{r}1996 \\
\text { Est. }\end{array}$ & $\begin{array}{l}1997 \\
\text { Prel. }\end{array}$ \\
\hline & \multicolumn{5}{|c|}{ (In millions of U.S. dollars) } \\
\hline Current account (excluding transfers) & -485.1 & -447.9 & -406.7 & -418.1 & -534.7 \\
\hline Trade balance $1 /$ & -448.3 & -365.0 & -337.4 & -350.9 & -483.9 \\
\hline Exports & 457.0 & 380.7 & 362.6 & 417.0 & 462.8 \\
\hline Im ports & -905.3 & -745.7 & -700.1 & -767.9 & -946.7 \\
\hline Non-factor services & -17.2 & -47.5 & 17.0 & -5.2 & -85.2 \\
\hline Credits & $\mathbf{7 2 . 7}$ & 102.0 & 121.8 & 93.9 & 159.7 \\
\hline Debits & -89.8 & -149.5 & -104.8 & -99.1 & -244.9 \\
\hline Factor services & -19.7 & -35.4 & -86.3 & .62 .1 & 34.4 \\
\hline Credits & 0.4 & 0.3 & 1.0 & 4.9 & 99.4 \\
\hline Debits & -20.1 & -35.7 & -87.3 & -67.0 & -65.0 \\
\hline Transfers & 131.2 & 170.0 & 189.2 & 140.5 & 187.6 \\
\hline Capital account & 305.6 & -19.3 & -86.6 & 66.4 & $\mathbf{2 5 2 . 3}$ \\
\hline Medium - and long-term borrowing & 381.7 & -23.7 & -171.3 & 19.0 & 68.5 \\
\hline Disbursem ents & 385.5 & 94.1 & 102.8 & 109.1 & 125.5 \\
\hline Amortization & -3.8 & -117.8 & -274.1 & -90.1 & -57.0 \\
\hline Other capital & -91.2 & 4.4 & 84.7 & 47.4 & 183.9 \\
\hline Errors and omissions &.- & -- & 0.5 & 42.5 & -7.3 \\
\hline Overall balance & -63.4 & -297.3 & -303.6 & .168 .7 & -102.0 \\
\hline Overall financing & 63.4 & 297.3 & 303.6 & 168.7 & 102.0 \\
\hline \multicolumn{6}{|l|}{ Increase in net international } \\
\hline Exceptional financing $3 /$ & 64.0 & 298.2 & 344.3 & 89.5 & 41.1 \\
\hline \multicolumn{6}{|l|}{ Memorandum items: } \\
\hline Gross usable reserves $4 /$ & 1.0 & 41.4 & 156.7 & 158.0 & 173.3 \\
\hline Debt service due $5 /$ & -. & -. & 35.2 & 49.5 & 53.8 \\
\hline \multirow[t]{2}{*}{ Stock of debt } & 596.9 & 998.5 & 1225.4 & 1371.0 & 1539.3 \\
\hline & \multicolumn{5}{|c|}{ (As a percent of GDP) } \\
\hline Current account, excl. transfers & -42.0 & -35.9 & -14.1 & -9.1 & -10.2 \\
\hline Gross usable reserves $6 /$ & -- & 0.7 & 2.7 & 2.5 & 2.2 \\
\hline Debt service due after relief $7 /$ & -- & -- & 7.3 & 9.7 & 8.6 \\
\hline Stock of debt & 51.7 & 80.1 & 42.5 & 30.0 & 29.4 \\
\hline
\end{tabular}

Sources: State Department and Statistics; and Fund staff estimates.

1/ There have been significant changes in the coverage of trade data and, as a result, caution is needed in comparing annual totals.

2/ Includes a valuation adjustment.

3/ Arrears and debt relief.

4/ Excludes debt service paid into a special account at the Netherlands Bank.

5/ After rescheduling.

6/ In months of imports.

$7 /$ As a percent of exports of goods and nonfactor services. 
Table 34. Georgia: Geographic Distribution of Trade, by Country, 1997 1/

\begin{tabular}{|c|c|}
\hline \multicolumn{2}{|c|}{$\begin{array}{c}\text { Exports } \\
\text { (Percent of total) }\end{array}$} \\
\hline Total & 100 \\
\hline Russia & 29.8 \\
\hline Turkey & 13.1 \\
\hline Azerbaijan & 10.9 \\
\hline Armenia & 8.2 \\
\hline Switzerland & 6.0 \\
\hline Bulgaria & 3.8 \\
\hline Ukraine & 3.7 \\
\hline Angilia & 3.0 \\
\hline Germany & 2.5 \\
\hline Turkmenistan & 2.5 \\
\hline Italy & 2.2 \\
\hline United Kingdom & 1.8 \\
\hline United States & 1.8 \\
\hline Kazakhstan & 1.6 \\
\hline Others & 9.1 \\
\hline \multicolumn{2}{|c|}{$\begin{array}{c}\text { Imports } \\
\text { (Percent of total) }\end{array}$} \\
\hline Total & 100 \\
\hline Russia & 13.4 \\
\hline Azerbaijan & 12.4 \\
\hline Turkey & 12.3 \\
\hline United States & 7.5 \\
\hline Ukraine & 6.0 \\
\hline Virgin Islands & 5.7 \\
\hline Bulgaria & 5.0 \\
\hline United Kingdom & 4.5 \\
\hline Italy & 4.4 \\
\hline Germany & 4.3 \\
\hline Armenia & 2.3 \\
\hline Netherland & 2.2 \\
\hline France & 1.9 \\
\hline Others & 18.1 \\
\hline
\end{tabular}

Source: State Department of Statistics.

1/ Refers to trade as recorded by the Customs Department in 1997. Data for earlier years are inconsistent with that of 1997. 
Table 35. Georgia: External Debt Outstanding

(In millions of U.S. dollars)

\begin{tabular}{|c|c|c|c|c|c|}
\hline & 1993 & 1994 & 1995 & 1996 & 1997 \\
\hline Total debt outstanding & 543.6 & 998.5 & 1225.4 & 1371.0 & 1539.3 \\
\hline Medium/long term & 543.6 & 957.9 & $1,109.5$ & $1,181.5$ & $1,280.1$ \\
\hline Public and publicly guaranteed & 543.6 & 957.9 & $1,109.6$ & $1,176.7$ & $1,275.8$ \\
\hline Official creditors & 543.6 & 957.9 & $1,109.6$ & $1,171.4$ & $1,271.0$ \\
\hline Multilateral & - & 1.0 & 93.5 & 176.7 & 263.5 \\
\hline World Bank & - & 1.0 & 86.1 & 163.0 & 233.7 \\
\hline Other & -- & - & 7.4 & 13.7 & 29.8 \\
\hline Bilateral & 543.6 & 956.9 & $1,016.1$ & 994.7 & $1,007.5$ \\
\hline BRO 1/ & 364.8 & 655.8 & 684.4 & 635.5 & 639.4 \\
\hline Russia & 142.6 & 156.3 & 167.1 & 175.4 & 179.3 \\
\hline Turkmenistan & $181.22 /$ & 440.3 & $453.23 /$ & 394.3 & 394.3 \\
\hline Armenia & 11.0 & 18.1 & 19.7 & 19.7 & 19.7 \\
\hline Azerbaijan & 7.6 & 15.0 & 15.7 & 16.3 & 16.3 \\
\hline Kazakhstan & 22.4 & 24.1 & 26.7 & 27.8 & 27.8 \\
\hline Other & 2.0 & 2.0 & 2.0 & 2.0 & 2.0 \\
\hline Non-BRO & 178.8 & 301.1 & 331.7 & 359.2 & 368.1 \\
\hline European Union & 88.5 & 151.7 & 160.8 & 155.1 & 145.0 \\
\hline Turkey & 10.3 & 42.0 & 45.4 & 47.9 & 48.8 \\
\hline Austria 4/ & 79.1 & 92.0 & 98.8 & 105.0 & 92.8 \\
\hline Other & 0.9 & 15.4 & 26.7 & 51.2 & 81.5 \\
\hline Private creditors & - & - & - & 5.3 & 4.8 \\
\hline Private non-guaranteed & - & - & - & 4.8 & 4.3 \\
\hline Short term & - & - & - & - & - \\
\hline IMF & - & 40.5 & 116.0 & 189.5 & 259.3 \\
\hline ESAF & - & - & - & 79.0 & 76.3 \\
\hline SBA & - & - & 33.1 & 31.6 & 30.5 \\
\hline STF & - & 40.5 & 82.9 & 79.0 & 152.5 \\
\hline
\end{tabular}

Sources: Georgian authorities; and Fund staff estimates.

1/ Debts to BRO countries other than Turkmenistan initially arose out of the conversion of correspondent account balances and technical credits from 1992 and the first half of 1993 into interstate loans in 1993.

2/ All gas arrears at end 1993 were converted into a 2 year loan at libor plus one percent.

3/ Under a preliminary agreement reached in February 1995, all of Georgia's obligations to Turkmenistan, including new gas arrears from 1994 and penalties were converted into a new debt of US\$453.2 million. After a reconciliation of accounts, concluded in May 1995, this figure was reduced to US\$440 million. About US\$46 million were written off in the context of a rescheduling agreem reached in March 1996.

4/ Refers to a credit from a commercial bank dating from 1989; included as official, since amounts due in 1993 and 1994 were rescheduled with an Austrian government guarantee. 
Table 36. Georgia: External Debt Service Obligations

(In millions of U.S. dollars)

\begin{tabular}{|c|c|c|c|c|c|c|c|c|c|}
\hline & \multicolumn{3}{|c|}{1995} & \multicolumn{3}{|c|}{1996} & \multicolumn{3}{|c|}{1997} \\
\hline & Int. & Prin. & Total & Int. & Prin. & Total & Int. & Prin. & Total \\
\hline Total debt service due $\mathrm{l} /$ & 35.2 & - & 35.2 & 48.7 & 0.9 & 49.5 & 50.3 & 3.5 & 53.8 \\
\hline Medium/long term & 35.2 & -- & 35.2 & 48.7 & 0.9 & 49.5 & 50.3 & 3.5 & 53.8 \\
\hline Public and publicly guaranteed & 35.2 & - & 35.2 & 48.4 & 0.9 & 49.3 & 50 & 3 & 53 \\
\hline Official creditors & 35.2 & -- & 35.2 & 48 & 0.9 & 48.9 & 49.7 & 2.5 & 52.2 \\
\hline Multilateral & 2.9 & -- & 2.9 & 6.6 & -- & 6.6 & 8.2 & 1.8 & 10 \\
\hline Bilateral 2/ & 32.3 & -. & 32.3 & 41.4 & 0.9 & 42.3 & 41.5 & 0.7 & 42.2 \\
\hline Private creditors & -. & - & -- & 0.4 & - & 0.4 & 0.3 & 0.5 & 0.8 \\
\hline Private non-guaranteed & -- & -- & -- & 0.3 & - & 0.3 & 0.3 & 0.5 & 0.8 \\
\hline Short term & -- & -- & - & - & - & - & - & -. & -- \\
\hline \multicolumn{10}{|l|}{ Memorandum items: } \\
\hline Debt-service ratio 3/ & 7.3 & -- & 7.3 & 9.5 & 0.2 & 9.7 & 8.1 & 0.5 & 8.6 \\
\hline
\end{tabular}

Sources: Georgian authorities, and Fund staff estimates.

1/ After rescheduling. Includes yearly US\$ 32 million payment to the special Dutch account for interest payments on rescheduled debt.

2/ Includes debt to the European Union.

3/ As a percent of exports of goods and non-factor services. 
Table 37. Georgia: Exchange Rates, August 1993-December 19971 1/

\begin{tabular}{|c|c|c|c|c|}
\hline & \multicolumn{2}{|c|}{ Lari per U.S. Dollar } & \multicolumn{2}{|c|}{$\begin{array}{c}\text { Lari per } \\
\text { thousands of ruble }\end{array}$} \\
\hline & $\begin{array}{c}\text { Average } \\
\text { During Period }\end{array}$ & $\begin{array}{l}\text { End of } \\
\text { Period }\end{array}$ & $\begin{array}{c}\text { Average } \\
\text { During Period }\end{array}$ & $\begin{array}{l}\text { End of } \\
\text { Period }\end{array}$ \\
\hline $1993 \mathrm{Q3}^{2}$ & 0.000 & 0.014 & 0.01 & 0.01 \\
\hline Q4 & 0.045 & 0.102 & 0.04 & 0.08 \\
\hline 1993 & $\ldots$ & 0.102 & $\ldots$ & 0.08 \\
\hline $1994 \mathrm{Q1}$ & 0.216 & 0.384 & 0.13 & 0.17 \\
\hline $\mathrm{Q} 2$ & 0.839 & 0.814 & 0.43 & 0.41 \\
\hline Q3 & 1.564 & 2.300 & 0.69 & 0.89 \\
\hline Q4 & 1.791 & 1.280 & 0.55 & 0.32 \\
\hline 1994 & 1.102 & 1.280 & 0.45 & 0.32 \\
\hline 1995 Q1 & 1.294 & 1.300 & 0.28 & 0.25 \\
\hline $\mathrm{Q} 2$ & 1.300 & 1.300 & 0.25 & 0.24 \\
\hline Q3 & 1.300 & 1.300 & 0.25 & 0.25 \\
\hline Q4 & 1.258 & 1.230 & 0.25 & 0.25 \\
\hline 1995 & 1.288 & 1.230 & 0.26 & 0.25 \\
\hline 1996 Q1 & 1.252 & 1.262 & 0.24 & 0.25 \\
\hline $\mathrm{Q} 2$ & 1.259 & 1.255 & 0.22 & 0.22 \\
\hline Q3 & 1.265 & 1.270 & 0.23 & 0.23 \\
\hline Q4 & 1.275 & 1.274 & 0.22 & 0.22 \\
\hline 1996 & 1.263 & 1.274 & 0.23 & 0.22 \\
\hline 1997 Q1 & 1.298 & 1.294 & 0.22 & 0.22 \\
\hline Q2 & 1.299 & 1.300 & 0.22 & 0.23 \\
\hline Q3 & 1.295 & 1.298 & 0.22 & 0.22 \\
\hline $\mathrm{Q} 4$ & 1.308 & 1.304 & 0.22 & 0.22 \\
\hline 1997 & 1.297 & 1.304 & 0.22 & 0.22 \\
\hline
\end{tabular}

Source: National Bank of Georgia.

1/Lari exchange rates are those prevailing on the Tbilisi Interbank Currency Exchange (TICEX).

2/ August and September 1993 only. 